\title{
Serotonin modulation of the basal ganglia circuitry: therapeutic implication for Parkinson's disease and other motor disorders
}

\author{
Vincenzo Di Matteo ${ }^{1}$, Massimo Pierucci ${ }^{1}$, Ennio Esposito ${ }^{1}$, Giuseppe Crescimanno ${ }^{2}$, \\ Arcangelo Benigno ${ }^{2}$ and Giuseppe Di Giovanni ${ }^{2, *}$ \\ ${ }^{1}$ Istituto di Ricerche Farmacologiche Mario Negri, Consorzio Mario Negri Sud, 66030 Santa Maria, \\ Imbaro (Chieti), Italy \\ ${ }^{2}$ Dipartimento di Medicina Sperimentale, Sezione di Fisiologia Umana G. Pagano, Università di Palermo, \\ C.so Tuköry 129, 90134 Palermo, Italy
}

\begin{abstract}
Several recent studies have emphasized a crucial role for the interactions between serotonergic and dopaminergic systems in movement control and the pathophysiology of basal ganglia. These observations are supported by anatomical evidence demonstrating large serotonergic innervation of all the basal ganglia nuclei. In fact, serotonergic terminals have been reported to make synaptic contacts with both substantia nigra dopamine-containing neurons and their terminal areas such as the striatum, the globus pallidus and the subthalamus. These brain areas contain a high concentration of serotonin (5-HT), with the substantia nigra pars reticulata receiving the greatest input. In this chapter, the distribution of different 5-HT receptor subtypes in the basal ganglia nuclei will be described. Furthermore, evidence demonstrating the serotonergic control of basal ganglia activity will be reviewed and the contribution of the different 5-HT receptor subtypes examined. The new avenues that the increasing knowledge of 5-HT in motor control has opened for exploring the pathophysiology and pharmacology of Parkinson's disease and other movement disorders will be discussed. It is clear that these avenues will be fruitful, despite the disappointing results so far obtained by clinical studies with selective 5-HT ligands. Nevertheless, these studies have led to a great increase in the attention given to the neurotransmitters of the basal ganglia and their connections.
\end{abstract}

Keywords: serotonergic receptors; basal ganglia; Parkinson's disease; motor disorders; dyskinesia; selective 5-HT drugs

\section{Introduction}

Since the 1950s, when serotonin $(5-\mathrm{HT})$ was discovered in the mammalian central nervous

\footnotetext{
*Corresponding author. Tel.: (+39) 091655821;

Fax: (+39) 0616555823; E-mail: g.digiovanni@unipa.it
}

system (CNS), an enormous amount of experimental evidence has revealed the pivotal role of this biogenic amine in a bewildering diversity of behavioural and physiological processes. This is not surprising, considering the almost ubiquitous distribution of 5-HT-containing axon terminals throughout the CNS, although 5-HT is synthesized by a small group of neurons within the raphe 
nuclei of the brain stem. Despite this broad axonterminal domain of 5-HT neurons, a closer examination reveals a preferential targeting of motor areas in the CNS (Steinbusch, 1981). For example, in the rat, there is a very dense innervation of the ventral horn of the spinal cord, the motor nucleus of the trigeminal, the facial motor nucleus and all components of the basal ganglia circuitry (Lavoie and Parent, 1990). It is thus likely that 5-HT plays a role in regulating the appropriate selection of voluntary movements by the basal ganglia, and abnormalities in 5-HT transmission might contribute to the neural mechanisms underlying disorders of basal ganglia origin, such as Parkinson's disease (PD), Tourette's syndrome and obsessive compulsive disorder (Chapter 24; Ring and Serra-Mestre, 2002). Indeed, biochemical evidence suggests that 5-HT transmission is abnormal in the basal ganglia of patients with PD (Hornykiewicz, 1998) and, moreover, in the movement abnormalities generally associated with the use of L-3,4-dihydroxyphenylalanine [levodopa (L-DOPA)] and classical antipsychotic drugs' (APDs) motor side effects (Bezard et al., 2001; Blackburn, 2004; Di Giovanni et al., 2006a; Chapters 22 and 23 in this volume).

During the last decades, advances in the understanding of receptors mediating the effect of 5-HT have represented one of the success stories of neuropharmacology. Many of the 5-HT receptors are found within the basal ganglia and most likely involved in the modulation of basal ganglia circuitry and in the pathology of their correlated disorders. Of particular interest with respect to the development of new treatments for PD and other motor disorders are the $5-\mathrm{HT}_{1 \mathrm{~A} / 1 \mathrm{~B}}$ and $5-\mathrm{HT}_{2 \mathrm{~A} / 2 \mathrm{C}}$ receptor subtypes. This will be the subject of further discussion in the remainder of this chapter. First, the 5-HT innervations of the basal ganglia and the distribution of 5-HT receptors throughout the various nuclei will be summarized. Thereafter, several aspects of 5-HT control of the pathophysiology of basal ganglia nuclei will be discussed.

Therefore, it is clear that a detailed understanding of the neurotransmitter function in each condition is not merely academic but can lead to a rationale for drug design and treatment strategies appropriate for that group of patients.

\section{5-HT innervation of basal ganglia}

More than 50 years have passed since Twarog and Page (1953) isolated an indole, identified as 5-HT, in the mammalian brain. Subsequently, Brodie et al. (1955) suggested that 5-HT might serve as a neurotransmitter in the CNS.

In vertebrates, the majority of the neurons containing 5-HT are grouped in nine nuclei named B1-B9, located in the medial part of the brain stem, generically called the raphe nuclei (Dahlström and Fuxe, 1964). These midline clusters can be divided into two major groups. The caudal or inferior group, localized in the medulla, contains the three nuclei projecting essentially to the grey matter of the spinal cord: the nucleus raphe magnus (NRM, cell group B5), nucleus raphe obscurus (NRO, cell groups B1, B2 and B3) and nucleus raphe pallidus (NRP, cell group B4). The rostral or superior group, located in the pons/mesenchephalon, contains the dorsal raphe nucleus (DRN, cell groups B6 and B7) and the medial raphe nucleus (MRN, cell group B8). These nuclei supply about $80 \%$ of the serotonergic innervation to the forebrain. Even if, in many brain areas, the innervation coming from the two nuclei overlaps, in certain regions, the innervation comes exclusively or prevalently from one nucleus only. For example, the dorsal hippocampus receives a serotonergic innervation only from the MRN; other areas innervated preferentially from this nucleus are the medial preoptic area, the suprachiasmatic nucleus, the olfactory bulb and the medial septum nucleus. The DRN innervates all the basal ganglia circuitry (Fig. 1), sending projections to the corpus striatum, the globus pallidus (GP), the subthalamic nucleus (STN), the substantia nigra $(\mathrm{SN})$ and the pedunculopontino nucleus (PPN), and provides most of the innervation of the prefrontal cortex, including the motor cortices. 5-HT-containing cell bodies of the raphe send projections to both dopaminergic (DAergic) and gamma-aminobutyric acidergic (GABAergic) cells in the $\mathrm{SN}$ and to their terminal 


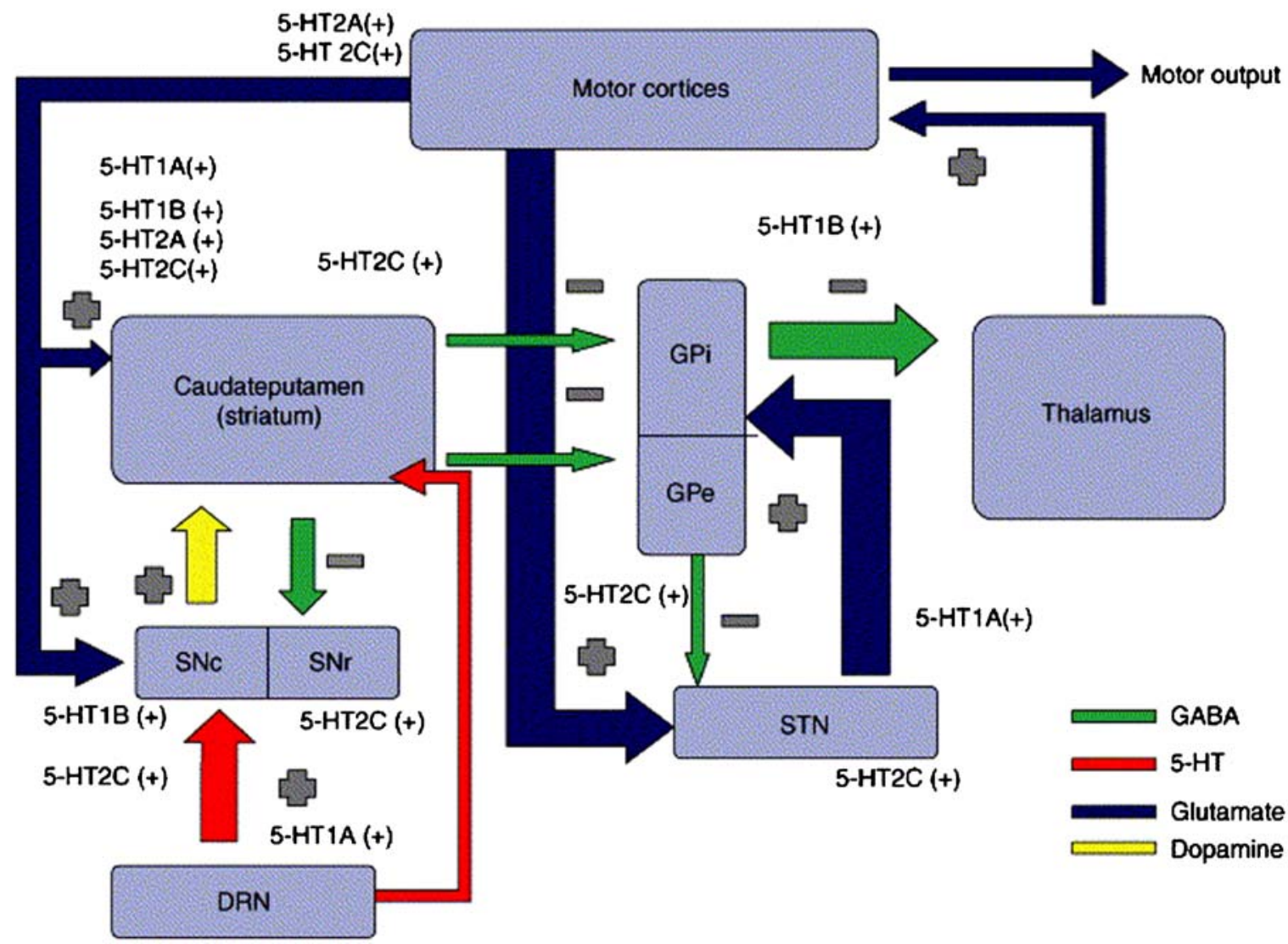

Fig. 1. Basal ganglia motor circuitry in Parkinson's disease (PD). 'Motor output' is used to generalize all descending motor pathways. During rest, the indirect motor output pathway ( $\mathrm{GPe} \rightarrow \mathrm{STN} \rightarrow \mathrm{GPi} \rightarrow$ thalamus) is primarily involved and the direct motor pathway (GPi $\rightarrow$ thalamus) is inactive. During periods of activity, the direct motor output pathway is primarily involved. The distribution of 5 -HT receptor subtypes in the basal ganglia is indicated based on reports using a variety of methods. Reduced inhibition of the tonically active STN neurons results in increased inhibition of the thalamus via the pallidothalamic pathway. Intense GPi stimulation effectively inactivates this structure, reducing the inhibitory influence upon the thalamus by GPi. Yellow arrow indicates degenerating nigrostriatal pathway associated with PD; thin lines are pathways with reduced activity; medium-width lines are physiologically normal pathways; thicker lines are over-active pathways implicated in PD. Proposed sites of action of known 5-HT receptor subtypeselective compounds associated with PD and L-DOPA-induced dyskinesias are far from clear, but a more detailed understanding of our present knowledge is given in the main text for each 5-HT therapeutic strategy. SNc, substantia nigra pars compacta; SNr, substantia nigra pars reticulata; GPi, internal segment of the globus pallidus; GPe, external segment of the globus pallidus; DRN, dorsal raphe nucleus; STN, subthalamic nucleus; (+) denotes excitatory pathway; and (-) denotes inhibitory pathway. Adapted with permission from Blackburn (2004). (See Color Plate 21.1 in color plate section.)

fields (Hervé et al., 1987; Van Bockstaele et al., 1993; Moukhles et al., 1997). Moreover, electron microscopy demonstrates the presence of synaptic contacts of $\left[{ }^{3} \mathrm{H}\right] 5-\mathrm{HT}$-labelled terminals with both DAergic and non-DAergic dendrites in the $\mathrm{SN}$ pars compacta $(\mathrm{SNc})$ and reticulata (SNr) (Hervé et al., 1987; Moukhles et al.,
1997; Lee et al., 2000). The DRN innervates, together with the MRN, the ventral part of the hippocampus, the nucleus accumbens and various nuclei of the thalamus, among them the ventral lateral nuclear group that processes motor information and the hippocampus (Azmitia and Segal, 1978; Jacobs and Azmitia, 
1992; McQuade and Sharp, 1995). Moreover, extensive serotonergic connections between the DRN and the MRN also exist (Jacobs and Azmitia, 1992).

\section{5-HT receptors' distribution within the basal ganglia nuclei}

A vast amount of research has led to the discovery and characterization of a plethora of 5-HT receptor subtypes. At present, seven classes of 5-HT $\left(5-\mathrm{HT}_{1-7}\right)$ receptors have been identified, which comprise at least 15 subtypes (Hoyer et al., 2002) (Table 1). This is not surprising, since with so many potential targets distributed throughout the CNS, 5-HT is a major neurotransmitter involved in such a large number of physiological and pathological processes.

The distribution of 5-HT receptors among the various basal ganglia structures has been widely investigated. Autoradiographic, in situ hybridization and binding studies, as well as functional and pharmacological investigations, showed a differential distribution of the various 5-HT receptor subtypes both within the basal ganglia nuclei and among the different mammalian species that were used in these studies (Waeber et al., 1990a). Strikingly, the described pattern of distribution and expression of these receptors is modified in the animal model of pathologies involving basal ganglia circuitry as well as in human patients. Nevertheless, this could be no more than an epiphenomenal effect.

\section{Striatum}

High concentrations of both receptor mRNA and protein of different 5-HT receptor subtypes have been found in the striata of various species.

$5-\mathrm{HT}_{1 \mathrm{~A}}$ was one of the first 5-HT receptor subtypes that was identified and pharmacologically characterized, and its distribution among different species of mammals has been widely investigated. So far, most of the receptor autoradiography, radioimmunohistochemistry and in

Table 1. Serotonin receptor subtypes

\begin{tabular}{|c|c|c|c|c|c|}
\hline Receptor & $\begin{array}{l}\text { Type of } \\
\text { receptor }\end{array}$ & $\begin{array}{l}\text { Effector } \\
\text { mechanisms }\end{array}$ & Subtypes & Location in the basal ganglia & Speculated function \\
\hline \multirow[t]{2}{*}{$5-\mathrm{HT}_{1}$} & $\begin{array}{l}\text { G protein } \\
\text { linked }\end{array}$ & $\begin{array}{l}\text { Inhibits adenylyl } \\
\text { cyclase, opens } \\
\mathrm{K}^{+} \text {channels }\end{array}$ & $\begin{array}{l}5-\mathrm{HT}_{1 \mathrm{~A}} \\
5-\mathrm{HT}_{1 \mathrm{~B}}\end{array}$ & $\begin{array}{l}\text { Caudate-putamen, subthalamic nucleus } \\
\text { Caudate-putamen, substantia nigra, globus } \\
\text { pallidus }\end{array}$ & $\begin{array}{l}\text { Anxiety, depression } \\
\text { Locomotion }\end{array}$ \\
\hline & & & $\begin{array}{l}5-\mathrm{HT}_{1 \mathrm{D}} \\
5-\mathrm{HT}_{1 \mathrm{E}} \\
5-\mathrm{HT}_{1 \mathrm{~F}}\end{array}$ & $\begin{array}{l}\text { Substantia nigra } \\
\text { Caudate-putamen } \\
\text { Caudate-putamen }\end{array}$ & Locomotion \\
\hline $5-\mathrm{HT}_{2}$ & $\begin{array}{l}\text { G protein } \\
\text { linked }\end{array}$ & $\begin{array}{l}\text { Stimulation of } \\
\text { phospholipase } \mathrm{C}, \\
\text { closing of } \mathrm{K}^{+} \\
\text {channels }\end{array}$ & $\begin{array}{l}5-\mathrm{HT}_{2 \mathrm{~A}} \\
5-\mathrm{HT}_{2 \mathrm{~B}} \\
5-\mathrm{HT}_{2 \mathrm{C}}\end{array}$ & $\begin{array}{l}\text { Nucleus accumbens, caudate-putamen } \\
\text { None detected in the basal ganglia } \\
\text { Nucleus accumbens, caudate-putamen, } \\
\text { substantia nigra, subthalamus }\end{array}$ & \\
\hline $5-\mathrm{HT}_{3}$ & $\begin{array}{l}\text { Ligand-gated } \\
\text { cation } \\
\text { channel }\end{array}$ & $\mathrm{Na}^{+}$current & $\begin{array}{l}5-\mathrm{HT}_{3 \mathrm{~A}} \\
5-\mathrm{HT}_{3 \mathrm{~B}} \\
5-\mathrm{HT}_{3 \mathrm{C}}\end{array}$ & $\begin{array}{l}\text { GABAergic projection neurons of } \\
\text { caudate-putamen }\end{array}$ & $\begin{array}{l}\text { Anxiety, depression, } \\
\text { emesis }\end{array}$ \\
\hline $5-\mathrm{HT}_{4}$ & $\begin{array}{l}\text { G protein } \\
\text { linked }\end{array}$ & $\begin{array}{l}\text { Stimulation of } \\
\text { adenylyl cyclase }\end{array}$ & $5-\mathrm{HT}_{4}$ & $\begin{array}{l}\text { GABAergic projection neurons of } \\
\text { caudate-putamen }\end{array}$ & Anxiety, depression \\
\hline $5-\mathrm{HT}_{5}$ & $\begin{array}{l}\text { G protein } \\
\text { linked }\end{array}$ & $\begin{array}{l}\text { Inhibits adenylyl } \\
\text { cyclase }\end{array}$ & $\begin{array}{l}5-\mathrm{HT}_{5 \mathrm{~A}} \\
5-\mathrm{HT}_{5 \mathrm{~B}}\end{array}$ & Caudate-putamen & $\begin{array}{l}\text { Motor control, feeding, } \\
\text { anxiety, depression, } \\
\text { learning, memory }\end{array}$ \\
\hline $5-\mathrm{HT}_{6}$ & $\begin{array}{l}\text { G protein } \\
\text { linked }\end{array}$ & $\begin{array}{l}\text { Stimulation of } \\
\text { adenylyl cyclase }\end{array}$ & $5-\mathrm{HT}_{6}$ & $\begin{array}{l}\text { Dendrites of GABAergic striatopallidal and } \\
\text { striatonigral neurons }\end{array}$ & Dopamine transmission \\
\hline $5-\mathrm{HT}_{7}$ & $\begin{array}{l}\text { G protein } \\
\text { linked }\end{array}$ & $\begin{array}{l}\text { Stimulation of } \\
\text { adenylyl cyclase }\end{array}$ & $5-\mathrm{HT}_{7}$ & Caudate-putamen, nucleus accumbens & $\begin{array}{l}\text { Locomotion, circadian } \\
\text { rhythms }\end{array}$ \\
\hline
\end{tabular}


situ hybridization studies have reported low or barely detectable levels of labelling for both $5-\mathrm{HT}_{1 \mathrm{~A}}$ receptor protein and mRNA in the caudate-putamen of the rat (Miquel et al., 1991; Riad et al., 1991; Kung et al., 1995; Wright et al., 1995), mouse (Schiller et al., 2003) and primate brain (Mengod et al., 1996). The same regional distribution has been found in the caudate and putamen nuclei of human brain, using postmortem radiolabelling and in vivo positron emission tomography (PET) with various radiotracers (Pike et al., 1995; Pasqualetti et al., 1996; Hall et al., 1997; Duncan et al., 1998; Ito et al., 1999). However, a recent study reported a patchy distribution of $5-\mathrm{HT}_{1 \mathrm{~A}}$ receptors confined to striosomes of the primate striatum characterized by poor calbindin immunostaining. In these compartments, the receptor density was equal to that in other enriched brain areas, such as some hippocampal fields, and it was increased in a 1-methyl 4-phenyl 1,2,3,6-tetrahydropyridine (MPTP)-lesioned primate model of PD, suggesting a key role for this receptor subtype in the control of movement by the basal ganglia (Frechilla et al., 2001).

The $5-\mathrm{HT}_{1 \mathrm{~B}}$ receptor subtype localization in the striatum has been widely demonstrated in various mammal brains. In rats and mice, early $\left[{ }^{3} \mathrm{H}\right] 5-\mathrm{HT}$ binding studies, using selective ligands as displacing agents for the $5-\mathrm{HT}_{1 \mathrm{~A}}$ receptor subtype, showed intermediate-to-low concentrations of $5-\mathrm{HT}_{1 \mathrm{~B}}$ binding or immunoreactivity sites in the caudate-putamen (Pazos and Palacios, 1985; Blurton and Wood, 1986; Verge et al., 1986; Waeber et al., 1989; Middlemiss and Hutson, 1990; Sari et al., 1999). In a first attempt to characterize the distribution of 5-HT receptors in the brains of different mammal species, autoradiographic data seemed to indicate a lack, in cats, guinea pigs, monkeys and humans, of receptors with a pharmacological profile similar to that of the rat and mouse 5-HT 1 в (Hoyer et al., 1986; Pazos et al., 1987a; Waeber et al., 1989). Similarities in the $5-\mathrm{HT}_{1 \mathrm{D}}$ distribution in the brains of these species to that of $5-\mathrm{HT}_{1 \mathrm{~B}}$ in rats and mice led to the hypothesis that these two receptor subtypes were species homologues (Waeber et al., 1989; del Arco et al., 1993). Subsequent findings, relative to the molecular cloning of $5-\mathrm{HT}_{1}$ receptor subtypes, showed the presence, in human brain, of two genes expressing different receptors displaying the pharmacology of the originally described $5-\mathrm{HT}_{1 \mathrm{D}}$ sites, named 5-HT $1 \mathrm{D} \alpha$ and 5-HT $\mathrm{HD}_{1 \mathrm{D}}$ (77\% sequence homology in the transmembrane domain). $5-\mathrm{HT}_{1 \mathrm{D} \beta}$ showed a $96 \%$ homology to the cloned rodent $5-\mathrm{HT}_{1 \mathrm{~B}}$ receptor. Following this new experimental evidence, the $5-\mathrm{HT}_{1 \mathrm{~B} / 1 \mathrm{D}}$ receptor nomenclature underwent a reassessment (for reviews, see Barnes and Sharp, 1999; Hoyer et al., 2002). According to the new classification, comparative studies showed binding sites for this receptor, as well as high hybridization signals for its mRNA, in the caudate-putamen of rodent brain (Bruinvels et al., 1994; Bonaventure et al., 1998) and the corresponding caudate and putamen in humans (Varnas et al., 2001, 2005); moreover, some authors showed a dorsoventral gradient in the distribution of both this receptor and its mRNA, with higher levels in the ventral as compared to the dorsal striatum (Compan et al., 1998; Varnas et al., 2001, 2005) in both rats and humans. According to the authors, this evidence, together with the complete lack of mRNA in both the $\mathrm{SN}$ and ventral pallidum, seems to indicate a localization of the $5-\mathrm{HT}_{1 \mathrm{~B}}$ receptor subtype on axon terminals arising from medium spiny neurons (MSNs) of the ventral striatal regions, thus confirming previous immunoreactivity and in situ hybridization studies in mouse and rat brain (Boschert et al., 1994; Sari et al., 1999). On the other hand, binding sites in the striatum may reflect both somatodendritic and presynaptic localizations of this receptor on striatal neurons (projection neurons and/or interneurons) or on thalamic/cortical afferents, respectively (Bonaventure et al., 1998).

The presence of $5-\mathrm{HT}_{1 \mathrm{D}}$ (namely, $5-\mathrm{HT}_{1 \mathrm{D} \alpha}$ ) receptor and mRNA in the striatum of rodents, primates and humans has been reported, even if weaker levels of both protein-binding and hybridization signals were observed with respect to the 5-HT 1B $_{\text {B }}$ (Bruinvels et al., 1993a). Similarly to $5-\mathrm{HT}_{1 \mathrm{~B}}$ receptors, some authors described a discrepancy in the distribution pattern of 5-HT $1 \mathrm{D}$ mRNA and its protein in the striatum, SN and GP of mouse brain and therefore hypothesized a 
presynaptic localization of $5-\mathrm{HT}_{1 \mathrm{D}}$ receptors in the latter two areas (Boschert et al., 1994). Finally, regarding the $5-\mathrm{HT}_{1}$ receptor family, Bruinvels et al. (1993b) reported the presence of the 5-HT $1 \mathrm{E}$ receptor subtype mRNA in both the caudate nucleus and putamen of primates, showing stronger hybridization signals in monkey brain than that obtained in human brain.

Both $5-\mathrm{HT}_{2 \mathrm{~A}}$ receptor subtype and its mRNA have been extensively demonstrated to be present in the striatum of various mammal species. Moreover, the described distribution pattern showed increasing gradients for this receptor in the rostrocaudal and mediolateral directions (Pazos et al., 1985, 1987b; Mengod et al., 1990; Pompeiano et al., 1994; Wright et al., 1995; LopezGimenez et al., 1997). In human brain, using the high-affinity radioligand $\left[{ }^{3} \mathrm{H}\right] \mathrm{MDL} 100907$, a high density of labelling has been shown to be distributed in patches throughout the caudate nucleus and putamen (Lopez-Gimenez et al., 1999). Regarding cellular distribution, the 5- $\mathrm{HT}_{2 \mathrm{~A}}$ receptors showed a somatodendritic localization, as demonstrated also by the correlation between the distribution of $5-\mathrm{HT}_{2 \mathrm{~A}}$ protein and its mRNA (Cornea-Hébert et al., 1999). Furthermore, a more prominent localization in dendrites than in cell bodies was found in the dorsolateral caudateputamen of rat brain, using immunocytochemistry (Rodríguez et al., 1999).

A number of studies have demonstrated a widespread distribution of the $5-\mathrm{HT}_{2 \mathrm{C}}$ receptor subtype in rat, monkey and human brains, particularly among the different basal ganglia structures. Moreover, marked differences have been revealed in the distribution of $5-\mathrm{HT}_{2 \mathrm{C}}$ mRNA and its level of expression within the different subregions of the basal ganglia (Hoffman and Mezey, 1989; Mengod et al., 1990; Wright et al., 1995; Eberle-Wang et al., 1997). Most labelled neurons in the striatum were efferent medium-sized neurons but not cholinergic interneurons, although recent polymerase chain reaction (PCR) evidence instead revealed high expression of $5-\mathrm{HT}_{2 \mathrm{C}}, 5-\mathrm{HT}_{6}$ and $5-\mathrm{HT}_{7}$ mRNAs in cholinergic interneurons (Bonsi et al., 2007a).

Neurons expressing $5-\mathrm{HT}_{2 \mathrm{C}}$ mRNA have been found in discrete areas of the caudate-putamen showing no preferential localization with substance $\mathrm{P}$, dynorphin or enkephalin, thus indicating that $5-\mathrm{HT}_{2 \mathrm{C}}$ receptors are not differentially expressed on the two major striatal output pathways (striatonigral and striatopallidal projection neurons). On the other hand, with regard to patch/ matrix striatal structures, $5-\mathrm{HT}_{2 \mathrm{C}}$ mRNA showed a preferential localization in the patch compartment areas, suggesting a role for this receptor in the modulation of striatal projections to the $\mathrm{SNc}$ (Gerfen, 1984, 1985; Ward and Dorsa, 1996).

Using various radioligands, some authors have reported the presence of $5-\mathrm{HT}_{3}$ receptors in the striatum of different mammals, albeit higher receptor densities have been found in the human caudate nucleus and putamen than in the corresponding structures of the rat brain (Barnes et al., 1990; Gehlert et al., 1991; Laporte et al., 1992; Abi-Dargham et al., 1993; Bufton et al., 1993; Parker et al., 1996; Morales et al., 1998; Fletcher and Barnes, 1999; Marazziti et al., 2001). Binding studies on homogenates of human putamen suggested a localization of these receptors on neurons that have their cell bodies within this region, such as GABAergic projection neurons, but not on DAergic neurons. Indeed, patients with diagnosed Huntington's disease showed decreased binding densities in the striatum, unlike those affected by DAergic cell loss associated with PD (Steward et al., 1993). Moreover, as for other brain areas, data obtained using synaptosomes isolated from rat striatum showed the presence in this area of functional presynaptic 5- $\mathrm{HT}_{3}$ receptors, besides the known postsynaptic localization (Nichols and Mollard, 1996; Ronde and Nichols, 1998; Nayak et al., 1999).

An analysis of the distribution of the $5-\mathrm{HT}_{4}$ receptor showed its presence in several components of the basal ganglia of different mammal species. Generally, the distribution pattern of the $5-\mathrm{HT}_{4}$ receptor binding sites in the striatum matched that observed for its mRNA in all the different species used in binding and in situ hybridization studies. However, some species' differences have been shown. Thus, ventromedial-to-dorsolateral-increasing gradients of labelling densities have been observed in the rat and mouse brain caudate-putamen (Waeber et al., 
1994; Vilaro et al., 1996), while it was less pronounced in the same structure of guinea pig brain; similarly, monkey and human caudate nuclei and putamens showed very high densities of receptor and mRNA binding sites but no apparent gradient in their distribution (Bonaventure et al., 2000; Vilaro et al., 2005). The decrease in binding densities following selective lesion of rat caudate-putamen indicated a somatodendritic localization of $5-\mathrm{HT}_{4}$ receptors on GABAergic projection neurons and cholinergic/GABAergic interneurons in this structure; on the other hand, following 6-hydroxydopamine (6-OHDA) lesion of the nigrostriatal pathway, there were no changes in striatal levels of receptor binding, clearly indicating that this receptor was not localized on DAergic terminals (Compan et al., 1996; Vilaro et al., 2005). These data are in agreement with postmortem studies on brains of patients with Huntington's disease or PD, showing a decrease in receptor binding only in the first group of patients (Reynolds et al., 1995; Vilaro et al., 2005).

Only moderate-to-low expression of $5-\mathrm{HT}_{5 \mathrm{~A}}$ receptor protein and mRNA has been found in the striatum of mouse, rat and human brain (Boess and Martin, 1994; Rees et al., 1994; Wesolowska, 2002). In particular, 5- $\mathrm{HT}_{5 \mathrm{~A}}$ immunoreactivity was detectable at low levels in MSNs of rat caudate-putamen (Oliver et al., 2000).

On the other hand, the $5-\mathrm{HT}_{6}$ receptor subtype has been shown to be particularly abundant in this area of the basal ganglia. High levels of both protein and mRNA expression have been found in the caudate-putamen of rat and pig brain (Monsma et al., 1993; Ruat et al., 1993a; Ward et al., 1995; Kohen et al., 1996; Yoshioka et al., 1998; Hirst et al., 2000) as well as in the caudate nucleus and putamen of human brain (Kohen et al., 1996; Hirst et al., 2003), thus demonstrating a similar distribution pattern for this receptor in the brains of these species. In contrast, only low levels of both $5-\mathrm{HT}_{6}$ receptor protein and mRNA have been found in the same brain areas of two different strains of mice (Hirst et al., 2003). As the regional distribution of $5-\mathrm{HT}_{6}$ receptor generally matched that found for the $5-\mathrm{HT}_{6}$ receptor mRNA, it is likely that the former is mainly localized on somas and/or dendrites of neurons. This conclusion is further supported by light and electron microscopy immunoreactivity data clearly showing the localization of this receptor on dendritic processes of spiny neurons in the striatum (Gerard et al., 1997; Hamon et al., 1999). Finally, selective lesion of 5-HT neurons by injection of 5,7-dihydroxytryptamine (5,7DHT) in the DRN has been shown to not affect the levels of 5- $\mathrm{HT}_{6}$ mRNA in the striatum of rat brain, thus confirming the postsynaptic localization of this receptor with respect to 5-HT neurons innervating this area (Gerard et al., 1996). Similarly, the lack of any difference in the levels of protein binding, following 6-OHDA selective lesion of the nigrostriatal pathway, demonstrates that the $5-\mathrm{HT}_{6}$ is also not located on membranes of DA neurons (Roberts et al., 2002).

Finally, the presence of the $5-\mathrm{HT}_{7}$ receptor subtype has been reported in the striatum of rodents as well as in the caudate nucleus and putamen of human brain, with a protein distribution pattern generally matching that of its mRNA. In addition, some species' differences in receptor densities were reported between human and rodent brain (Ruat et al., 1993b; Wesolowska, 2002; Martin-Cora and Pazos, 2004; Varnas et al., 2004).

\section{Substantia nigra and globus pallidus}

Very low levels of binding have been found in the $\mathrm{SN}$ or the GP of mouse, rat and human brains for both $5-\mathrm{HT}_{1 \mathrm{~A}}$ receptor protein and its mRNA (Khawaja, 1995; Kung et al., 1995; Wright et al., 1995; Hall et al., 1997; Schiller et al., 2003). Interestingly, some authors showed high binding of $\left[{ }^{3} \mathrm{H}\right]$ zolpidem in the rat $\mathrm{SN}$ in contrast to low binding observed in the same region of human brain (Duncan et al., 1998). By contrast, among the basal ganglia nuclei, the highest levels of $5-\mathrm{HT}_{1 \mathrm{~B}}$ protein bindings were found in both the SN and the GP of different mammal species. Unlike the striatum, in situ hybridization studies failed to reveal the presence of $5-\mathrm{HT}_{1 \mathrm{~B}}$ mRNA in these structures. Taken together, therefore, these data seem to suggest a presynaptic localization of 
this receptor subtype, presumably on terminals of striatal afferents (Pazos et al., 1987a; Boschert et al., 1994; Bruinvels et al., 1994; Bonaventure et al., 1998; Sari et al., 1999; Varnas et al., 2001, 2005), where it acts as heteroreceptor (Barnes and Sharp, 1999). Moreover, the levels of $5-\mathrm{HT}_{1 \mathrm{~B}}$ binding sites in these areas after selective lesion of nigral DAergic cells or striatal neurons, as well as radioligand studies on postmortem human brain of patients who had suffered degenerative movement disorders, clearly demonstrate the localization of this receptor on striatonigral and striatopallidal GABAergic afferents (Waeber et al., 1990b; Castro et al., 1998; Compan et al., 1998). Similarly to the $5-\mathrm{HT}_{1 \mathrm{~B}}$ subtype, radiolabelled sites for $5-\mathrm{HT}_{1 \mathrm{D}}$ receptors were found in these structures, despite the lower densities as compared to the previous receptor (partially due to the lack of specific radioligand), while in situ hybridization studies showed a lack of its mRNA (Bruinvels et al., 1993a, 1994). Again, these data, together with receptor and mRNA distribution in the striatum previously reported, are in line with a putative localization on axon terminals in these areas.

Regarding the 5- $\mathrm{HT}_{2}$ family, intermediate levels of $5-\mathrm{HT}_{2 \mathrm{~A}}$ receptor $\mathrm{mRNA}$ were found in the $\mathrm{SNc}$, $\mathrm{SNr}$ and pars lateralis of rat brain (Mengod et al., 1990; Pompeiano et al., 1994; Wright et al., 1995). Regarding receptor distribution, as mentioned above, there is a general concordance between the distributions of $5-\mathrm{HT}_{2 \mathrm{~A}}$ protein and its mRNA. Early studies found high concentrations of $\left[{ }^{3} \mathrm{H}\right]$ ketanserin binding in the $\mathrm{SNc}$ and the $\mathrm{SNr}$ in rats while only very low concentrations of this receptor have been shown in the GP (Pazos et al., 1985, 1987b). Nevertheless, some recent immunohistochemistry and autoradiography studies found lower levels of 5- $\mathrm{HT}_{2 \mathrm{~A}}$ receptors expressed in these areas (Cornea-Hébert et al., 1999; Lopez-Gimenez et al., 1999; Bubser et al., 2001). These discrepancies in receptor concentrations in the $\mathrm{SN}$ could be explained by the use in previous studies of some radioligands, such as $\left[{ }^{3} \mathrm{H}\right]$ ketanserin, which has been shown to have a high affinity for nonserotonergic sites, as well as its known selectivity for the 5- $\mathrm{HT}_{2}$ receptor family (Lopez-Gimenez et al., 1997). Finally, the presence of this receptor subtype in the GP of rat brain has been confirmed by recent immunohistochemistry data showing that about $70 \%$ of neurons expressing the $5-\mathrm{HT}_{2 \mathrm{~A}}$ receptor project to the striatum (Bubser et al., 2001). Neither 5-HT $2 \mathrm{C}$ mRNA nor receptor protein has been found in the GP or in the entopeduncular nucleus (EPN) while neurons showing labelling for this receptor have been found in both the SNc and the SNr. Furthermore, the distribution pattern of $5-\mathrm{HT}_{2 \mathrm{C}}$ in this area showed a marked rostrocaudal labelling gradient, characterized by higher receptor densities in caudal regions of both nuclear subdivisions. Finally, with regard to cellular localization, receptor expression seems to be confined to GABAergic neurons but not to DAergic cell bodies (Van Bockstaele et al., 1994; Van Bockstaele and Pickel, 1995; Steffensen et al., 1998; Di Giovanni et al., 2001).

The $5-\mathrm{HT}_{3}$ receptor subtype has been detected by membrane binding essays and immunolabelling in the SN of both rat and human brain (Laporte et al., 1992; Bufton et al., 1993; Gehlert et al., 1993; Doucet et al., 1999). Nevertheless, only lightly detectable receptor densities have been shown for this area.

The presence of $5-\mathrm{HT}_{4}$ receptor protein, but not its mRNA, has been reported in both the GP and the SN of different mammal species, with the highest densities in the latter area, thus supporting the idea of a localization of this receptor on striatopallidal and striatonigral terminals (Compan et al., 1996; Ullmer et al., 1996; Vilaro et al., 1996; Bonaventure et al., 2000). Moreover, $5-\mathrm{HT}_{4}$ receptor binding sites in the rat $\mathrm{SN}$ were confined to the pars lateralis, while in guinea pig brain, a wider distribution was observed in the same area, with most of the $\mathrm{SNr}$ being strongly labelled (Waeber et al., 1994; Vilaro et al., 2005); in human and monkey brain, the distribution pattern resembled that of guinea pig brain.

Finally, with regards to the last three 5-HT receptor families, only moderate-to-low concentrations of both receptor proteins and mRNA have been found in the SN and the GP of rat and human brain for the 5- $\mathrm{HT}_{5 \mathrm{~A}}$ (Rees et al., 1994; Oliver et al., 2000), 5- $\mathrm{HT}_{6}$ (Kohen et al., 1996; 
Gerard et al., 1997; Hamon et al., 1999; Roberts et al., 2002; Hirst et al., 2003) and 5-HT 7 (Ruat et al., 1993b; Martin-Cora and Pazos, 2004; Varnas et al., 2004) receptor subtypes.

\section{Subthalamic nucleus}

So far, little evidence exists regarding the presence of moderate-to-low concentrations of $5-\mathrm{HT}_{1 \mathrm{~A}}$, $5-\mathrm{HT}_{4}, 5-\mathrm{HT}_{5}$ and $5-\mathrm{HT}_{6}$ receptors and/or their mRNA in the STN (Pompeiano et al., 1992). By contrast, high hybridization signals were found for both $5-\mathrm{HT}_{1 \mathrm{~B}}$ and $5-\mathrm{HT}_{2 \mathrm{C}}$ receptor mRNAs in the rodent brain (Bruinvels et al., 1994; Eberle-Wang et al., 1997).

\section{5-HT modulation of basal ganglia circuitry}

The 5-HT modulation of DAergic nigrostriatal function, in terms of control of DA SNc neuron firing discharge and DA release in the striatum, has been extensively reviewed in Chapters 2 and 3 . Therefore, we will not discuss this subject and we refer the readers to these two chapters.

\section{5-HT modulation of striatal activity}

In agreement with anatomical data, most of the reports on this subject indicate that striatal cells are predominantly affected by dorsal raphe (DR) stimulation, with the median raphe stimulation being unable to alter striatal cell activity directly (Olpe and Koella, 1977; Davies and Tongroach, 1978). In addition, it has been found that suppression of spontaneous firing activity is the main response of cultured striatal cells (Yakel et al., 1988) in vivo following DRN stimulation, and excitation being observed in only about $10 \%$ of them. Nevertheless, a rebound excitation was observed in some cells that were initially inhibited. Local application of 5-HT was found to produce changes similar to that caused by raphe stimulation, and most of the cells responsive to the raphe stimulation were also affected by nigral stimulation (Davies and Tongroach, 1978). However, using intracellular recording techniques, Kitai and co-workers (Vandermaelen et al., 1979) found that
DRN stimulation was consistently capable of generating excitatory postsynaptic potentials. These findings were subsequently repeated in the laboratory by the authors, and it was indicated that non-5-HT DRN-striatal neurons could be involved in striatal responses to 5-HT. They also showed that the increase of the firing frequency in rat neostriatal MSNs induced by 5-HT depended on reducing voltage-dependent potassium currents (Park et al., 1982; Stefani et al., 1990; Wilms et al., 2001).

Stimulation of postsynaptic $5-\mathrm{HT}_{1 \mathrm{~A}}$ receptors by 8 -hydroxy-2-(di- $n$-propylamino)tetralin (8-OHDPAT) induced an increase in locomotor activity (Mignon and Wolf, 2002). Moreover, Gerber et al. (1988) and Matsubara et al. (2006) reported that $5-\mathrm{HT}_{1 \mathrm{~A}}$ receptor stimulation has an anti-parkinsonian effect in 6-OHDA-lesioned rats, inducing a robust contralateral rotational behaviour. Current theories of circling behaviour hypothesize that the animal turns away from the basal ganglia output, where activity has been reduced. Moreover, the stimulation of $5-\mathrm{HT}_{1 \mathrm{~A}}$ receptors has been shown to be capable of inducing contralateral rotation also following degeneration of the DRN (Blackburn et al., 1984; Gerber et al., 1988). This rotational behaviour has been explained by a supersensitivity of $5-\mathrm{HT}_{1 \mathrm{~A}}$ receptors in the $\mathrm{SNc}$ of the DA-lesioned rats, resulting in an increase of DA in the striatum (Blackburn et al., 1984; Gerber et al., 1988). In agreement with this theory, tandospirone, a highly potent and selective $5-\mathrm{HT}_{1 \mathrm{~A}}$ receptor agonist, remarkably potentiated the contralateral turning induced by apomorphine (Matsubara et al., 2006). Nevertheless, it has been shown that 8-OHDPAT can also induce ipsilateral turning in unilateral 6-OHDA-lesioned rats (Mignon and Wolf, 2002, 2007).

The discrepancies notwithstanding these findings are valuable in demonstrating the potential utility of drugs that possess $5-\mathrm{HT}_{1 \mathrm{~A}}$ in the symptomatic treatment of $\mathrm{PD}$. The $5-\mathrm{HT}_{1 \mathrm{~A}}$ agonists might inhibit 5-HT release, acting presynaptically (Gerber et al., 1988), or have a postsynaptic action (Lucas et al., 1997; Matsubara et al., 2006), decreasing striatal glutamate release from corticofugal projections, without involving 
direct activation of $\mathrm{D}_{2}$ receptors (Antonelli et al., 2005; Mignon and Wolf, 2005, 2007). Similarly, WAY 100135 increased glutamate (GLU) outflow in the striatum of rats (Dijk et al., 1995). These findings suggest that $5-\mathrm{HT}_{1 \mathrm{~A}}$ receptor stimulation could give rise to a decrease in the corticofugal glutamate drive (e.g. to the striatum or the STN) that could ultimately be manifested as decreased activation of the output nuclei of the basal ganglia (medial GPi and $\mathrm{SNr}$ ). A reduction in excitatory drive to these output nuclei would lead to a disinhibition of the motor thalamus, thereby ameliorating the motor deficits of PD (Mignon and Wolf, 2007). These results suggest that $5-\mathrm{HT}_{1 \mathrm{~A}}$ agonists could have therapeutic potentials for the treatment of PD by modulating neuronal activities of non-DAergic pathways, such as the excitatory amino acid pathways in the basal ganglia.

5-HT released from serotonergic terminals in the striatum exerts a negative feedback on its own neuronal activity via $5-\mathrm{HT}_{1 \mathrm{~B}}$ as well as $5-\mathrm{HT}_{1 \mathrm{~A}}$ autoreceptors. Indeed, stimulation of $5-\mathrm{HT}_{1 \mathrm{~B}}$ receptors, localized on the terminals of 5-HT neurons, reduced 5-HT release and also modulated L-DOPA metabolism to DA in the striatum (Knobelman et al., 2000; Carta et al., 2007). Several in vivo electrophysiological and neurochemical studies suggest an important role of the $5-\mathrm{HT}_{1 \mathrm{~B}}$ receptor in modulating the activity of mesostriatal DAergic neurons. Indeed, $5-\mathrm{HT}_{1 \mathrm{~B}}$ receptor stimulation enhances striatal DAergic activity, generally attributed to an inhibition of GABA release and a consequent disinhibition of DA neuronal activity (see Chapters 2 and 3). Rats with unilateral DRN lesions showed contralateral turning in response to the putative $5 \mathrm{HT}_{1 \mathrm{~B}}$ agonist RU 24969, while a much weaker effect was revealed in 6-OHDA-lesioned rats (Gerber et al., 1988). 5- $\mathrm{HT}_{1 \mathrm{~A}}$ and 5-HT $1 \mathrm{~B}$ receptors appear to act synergistically in reducing 5-HT transmission in the basal ganglia, and it is important to note that low doses of agonists for these receptors are able to suppress dyskinesia, without affecting the antiparkinsonian effect of L-DOPA in the presence of spared DA terminals, suggesting an early use of these drugs to counteract the development of dyskinesia in PD patients (see Chapter 22).
The 5- $\mathrm{HT}_{2}$ family has been intensively investigated in the striatum. Compelling data by Blier and colleagues (el Mansari et al., 1994; el Mansari and Blier, 1997) concerning single-unit recordings coupled with microiontophoresis in vivo, in rats, guinea pigs and $5-\mathrm{HT}_{2 \mathrm{C}}$ receptor mutant mice, support the hypothesis of an inhibitory action of the 5-HT system on the neuronal activity of the striatum [presumably MSNs] that through the activation of $5-\mathrm{HT}_{2}$ receptors. These authors investigated only in the head of the caudate nucleus and reported an inhibitory effect of 5 -HT, mimicked by the $5-\mathrm{HT}_{2 \mathrm{~A}}$ receptor agonist 1-(2,5-dimethoxy-4-iodophenyl)-2-aminopropane (DOI) and the 5- $\mathrm{HT}_{2 \mathrm{C}}$ receptor agonist m-chlorophenylpiperazine (mCPP) (el Mansari et al., 1994; el Mansari and Blier, 1997). It is noteworthy that significantly less quisqualate was required to activate neurons in the caudate nucleus of $5-\mathrm{HT}_{2}$ mutant mice than in the wild-type mice, suggesting that $5-\mathrm{HT}_{2 \mathrm{C}}$ receptors serve a tonic inhibitory role in membrane excitability (Rueter et al., 2000). Strikingly, neither the selective $5-\mathrm{HT}_{2 \mathrm{~A}}$ agonist MDL 100907 nor clozapine antagonized DOI or $\mathrm{mCPP}$ in the caudate nucleus in mice. The authors suggested that DOI and MCPP might be acting in the caudate nucleus through an atypical $5-\mathrm{HT}_{2}$ receptor yet to be characterized and a hypothesis that has not been investigated by successive studies. More likely, this lack of antagonism depends on the pharmacological design of the experiments. Indeed, in rats, el Mansari and Blier (1997) showed that the inhibitory effect of DOI, but not that of mCPP, was antagonized by a 4-day treatment with metergoline and ritanserin, indicating that the suppressant effect of DOI may be mediated by $5-\mathrm{HT}_{2 \mathrm{~A}}$ receptors in the head of the caudate nucleus. Contrary evidence has been shown by an in vivo study in which only excitation of the striatal neurons induced by microiontophoretical application of 5-HT was revealed, while DOI caused a preferential inhibitory response, highlighting diverse effects of 5-HT in different parts of the striatum (Wilms et al., 2001).

Recently, the role of serotonergic control on striatal cholinergic interneurons has been explored in vitro (Blomeley and Bracci, 2005; Bonsi et al., 
2007a). Striatal acetylcholine (ACh), and its interplay with DA, has long been recognized as playing a crucial role in voluntary movement (Duvoisin, 1967). In the striatum, ACh is mainly released by a population of large aspiny interneurons (LAIs) (Phelps et al., 1985; Zhou et al., 2002; Tepper and Bolam, 2004). Pakhotin and Bracci (2007) have shown that LAIs exerted a strong inhibitory control over the neighbouring striatal MSNs via inhibition of their GLUergic input. These effects are presynaptic and mediated by both $\mathrm{M}_{2}$ and $\mathrm{M}_{3}$ muscarinic receptors, both present on corticostriatal terminals. 5-HT strongly and reversibly increased spontaneous firing rates of LAIs in vitro via a reversible reduction of two pharmacologically and kinetically distinct afterhyperpolarizations (AHPs) that play an important role in limiting the excitability of cholinergic interneurons (Blomeley and Bracci, 2005). Blomeley and Bracci (2005), furthermore, showed that $5-\mathrm{HT}_{2}$ receptors were responsible for the excitatory effects of 5-HT in cholinergic interneurons, although they could not identify the 5-HT receptor subtype involved since they used $\alpha$-methyl-5-HT and ketanserin, highly unspecific ligands. Recently, Bonsi et al. (2007a) managed to rule out the role of $5-\mathrm{HT}_{2 \mathrm{~A}}$ showing that only the pretreatment with the selective $5-\mathrm{HT}_{2 \mathrm{C}}$ antagonist RS 102221 caused a significant reduction in the 5-HT-induced depolarization of cholinergic interneurons. This evidence was strongly supported by PCR analysis data showing that the $5-\mathrm{HT}_{2 \mathrm{C}}$ receptors are expressed by about $80 \%$ of LAIs in contrast to a sporadic expression of the $5-\mathrm{HT}_{2 \mathrm{~A}}$ subtypes. Accordingly, the response of striatal cholinergic interneurons to the 5-HT was partially blocked by phospholipase C (PLC) inhibitor, the transduction pathways linked to the $5-\mathrm{HT}_{2 \mathrm{C}}$ receptor subtypes. Thus, 5-HT induces cell depolarization and increase in firing frequency, acting through postsynaptic $5-\mathrm{HT}_{2 \mathrm{C}}$ receptors, probably causing inhibition of $\mathrm{K}^{+}$currents or increase of a cationic conductance in striatal cholinergic interneurons. In the light of these recent results, 5- $\mathrm{HT}_{2 \mathrm{C}}$ agonists might reduce striatal MSN activity indirectly via an increase of the inhibitory cholinergic tone. Moreover, 5- $\mathrm{HT}_{6}$ and $5-\mathrm{HT}_{7}$ receptor subtypes are also involved in the potent excitatory effect of $5-\mathrm{HT}$ but not in that of $5-\mathrm{HT}_{3}$ and $5-\mathrm{HT}_{4}$ (Bonsi et al., 2007a). Therefore, modulating the activity of cholinergic striatal interneurons by $5-\mathrm{HT}_{2 \mathrm{C}}, 5-\mathrm{HT}_{6}$ or $5-\mathrm{HT}_{7}$ receptors may have positive therapeutic benefits for motor diseases.

In concordance with these inhibitory 5-HT effects on MSNs through the activation of $5-\mathrm{HT}_{2 \mathrm{C}}$ receptors, there is the behavioural evidence that caudate injections of 5-HT provoked contraversive turning, while conversely, intracaudate methysergide induced ipsiversive circling (James and Starr, 1980). In addition, the facilitation by hyoscine and the attenuation by eserine of the 5-HT-induced contraversive circling, together with the converse effects of these drugs on methysergide-evoked ipsiversive rotations, are consistent with raphecaudate 5-HT fibres synapsing directly with, and exciting, striatal cholinergic neurons. Given that motor behaviour recruits multiple striatal neurotransmitter systems, recent attention has focused on the interaction between DA and 5-HT receptors. In the intact striatum, several studies have consistently demonstrated that intrinsic 5- $\mathrm{HT}_{2}$ receptors can modify $\mathrm{DA}$ function and have postulated divergent roles for $5-\mathrm{HT}_{2 \mathrm{~A}}$ and $5-\mathrm{HT}_{2 \mathrm{C}}$ receptor subtypes (Lucas et al., 2000; Porras et al., 2002). 5- $\mathrm{HT}_{2 \mathrm{~A}}$ antagonists reduce hyperlocomotion induced by cocaine, amphetamine and 3,4-methylenedioxymethyamphetamine (MDMA) (Kehne et al., 1996; O’Neill et al., 1999), whereas $5-\mathrm{HT}_{2 \mathrm{C}}$ receptor antagonists have been shown to enhance or reduce these effects, depending upon the compounds and neuronal sites studied (Filip and Cunningham, 2002; Fletcher et al., 2002; Filip et al., 2004). Recent studies by Walker's group have shown that, following DA depletion, $\mathrm{D}_{1}$-induced locomotor activity can be reduced by antagonism of striatal $5-\mathrm{HT}_{2 \mathrm{~A}}$, but not $5-\mathrm{HT}_{2 \mathrm{C}}$, receptors (Bishop et al., 2005). This preferential involvement of the $5-\mathrm{HT}_{2 \mathrm{~A}}$ subtype is confirmed by the evidence that intrastriatal injections of the selective $5-\mathrm{HT}_{2 \mathrm{C}}$ antagonist RS 102221 had no effect on motor activity; conversely, the $5-\mathrm{HT}_{2 \mathrm{~A}}$ agonist DOI induced motor behaviour in neonatal 6-OHDA-lesioned rats, which was attenuated by the $5-\mathrm{HT}_{2 \mathrm{~A}}$ receptor antagonism (Bishop et al., 2004). 
Interestingly, recent pharmacological data and lesion studies have established that the biosynthesis of neuropeptides in the striatum is regulated by the 5-HT innervation originating from the DRN, suggesting that 5-HT in the striatum might exert a metabolic regulatory function on the biosynthesis of neuropeptides rather than acting as an ion channel modulator (Horner et al., 2005; D'Addario et al., 2007).

\section{5-HT modulation of SNr activity}

The $\mathrm{SNr}$ neurons receive the largest 5-HT innervation from the DRN of all brain regions (Fibiger and Miller, 1977; Corvaja et al., 1993) and express a high level of 5-HT receptors, which are both postsynaptic and located on the somatodendritic region of $\mathrm{SNr}$ neurons and postsynaptic on terminals of $\mathrm{SNr}$ inputs. It has been calculated that the density of 5-HT-immunoreactive varicosities in the $\mathrm{SNr}$ is in the order of $9 \times 10^{6} / \mathrm{mm}^{3}$, of which about $74 \%$ form synaptic specializations with GABAergic projection neurons (Moukhles et al., 1997). This picture gives an idea of the great influence that 5-HT could have on the activity of $\mathrm{SNr}$ neurons. Early studies have revealed a primarily inhibitory action of 5-HT on $\mathrm{SNr}$ neurons. Electrical stimulation of the DRN caused mostly inhibitory responses in the $\mathrm{SNr}$, as measured by single-unit extracellular recordings in vivo (Fibiger and Miller, 1977). Similarly, the iontophoresis of 5-HT into the $\mathrm{SN}$ produced mixed, although mostly inhibitory, effects in the $\mathrm{SNr}$ (Dray et al., 1976; Collingridge and Davies, 1981). The inhibition of $\mathrm{SNr}$ neurons by $5-\mathrm{HT}$ is supported by the finding that unilateral injection of 5-HT, 5-HT $1 \mathrm{D}$ agonist and selective serotonin reuptake inhibitors (SSRIs) into the $\mathrm{SNr}$ of freely moving rats elicited a contraversive circling behaviour (James and Starr, 1980; Blackburn et al., 1981; Oberlander et al., 1981; Higgins et al., 1991; Bata-Garcia et al., 2002) as muscimol does (Oberlander et al., 1981). In spite of this evidence, Lacey and co-workers have shown, by using in vitro electrophysiological methods, that 5-HT not only directly excites $\mathrm{SNr}$ neurons but also disinhibits them by reducing GABA release from striatonigral terminals, acting on presynaptic
5- $\mathrm{HT}_{1 \mathrm{~B}}$ receptors (Rick et al., 1995; Stanford and Lacey, 1996). On the other hand, a subsequent electrophysiological in vitro study demonstrated also a direct inhibitory action of 5-HT on $\mathrm{SNr}$ neurons (Gongora-Alfaro et al., 1997). 5-HT and the 5-HT-uptake inhibitor duloxetine reduced the firing rate of the majority of $\mathrm{SNr}$ neurons recorded, suggesting that synaptically released endogenous 5-HT act directly on 5-HT 1 B receptors located in these neurons. The agonists that mimicked that effect were only of the $5-\mathrm{HT}_{1 \mathrm{~B}}$ class (CP 93129 and TFMPP). Neither the 5-HT 2 antagonist ritanserin nor the $\mathrm{GABA}_{\mathrm{A}}$ antagonist bicuculline were able to block that inhibition, suggesting that, in addition to an indirect action (Stanford and Lacey, 1996), some SNr neurons may be directly inhibited by 5-HT.

The 5-HT-induced excitation observed in the majority of the $\mathrm{SNr}$ neurons recorded is most probably mediated by a direct action on $5-\mathrm{HT}_{2}$ receptors being blocked by ketanserin and ritanserin and mimicked by $\alpha$-methyl-5-HT, unselective antagonists and agonists of the $5-\mathrm{HT}_{2}$ receptor subtype (Rick et al., 1995; Stanford and Lacey, 1996). In addition, Gongora-Alfaro and colleagues' in vitro study revealed that 5-HT could excite about half of the $\mathrm{SNr}$ neurons tested; this effect was seen in the neurons blocked by methysergide, thus confirming the involvement of $5-\mathrm{HT}_{2}$ receptors (Gongora-Alfaro et al., 1997). The above experimental evidence, although underlining a pivotal role for the $5-\mathrm{HT}_{2}$ receptor subtype in the modulation of $\mathrm{SNr}$ neurons, does not discriminate the involvement of different subtypes. We have tried to answer this question, and consistent with the aforementioned evidence, we showed that selective $5-\mathrm{HT}_{2 \mathrm{C}}$ activation excites $\mathrm{SNr}$ neurons in vivo (Di Giovanni et al., 2001; Invernizzi et al., 2007). This effect was evident after both systemic administration and local microiontophoretic application of mCPP and Ro 60-0175 (Di Giovanni et al., 2001; Invernizzi et al., 2007). As further confirmation of a selective activation of $5-\mathrm{HT}_{2 \mathrm{C}}$ receptors, excitatory effects of $\mathrm{mCPP}$ and Ro 60-0175 were blocked by pretretment with SB 242084 and SB 243213, potent and selective $5-\mathrm{HT}_{2 \mathrm{C}}$ antagonists. An interesting finding of our first study was the differential effect exerted by 
mCPP on subpopulations of $\mathrm{SNr}$ neurons. Thus, mCPP caused a marked excitation of the so-called $\mathrm{P}(0)$ non-DA neurons in the $\mathrm{SNr}$, whereas it did not affect the $\mathrm{P}(+)$ neurons. These neurons are identified on the basis of the presence $\mathrm{P}(+)$ or the absence $\mathrm{P}(0)$ of an excitatory response to a noxious stimulus (footpinch). There is evidence that $\mathrm{P}(+)$ neurons in the $\mathrm{SNr}$ are GABAergic interneurons that exert a direct inhibitory influence on DA neurons in the $\mathrm{SNc}$, whereas $\mathrm{P}(0)$ cells represent $\mathrm{SNr}$ projection neurons. Thus, $\mathrm{mCPP}$ caused a marked excitation of presumed $\mathrm{SNr}$ projection neurons but did not modify the $\mathrm{SNr}$ interneuron firing discharge (Di Giovanni et al., 2001). These data have been confirmed using Ro 60-0175, the most selective agonist to date, which caused excitation only in half of the $\mathrm{SNr}$ neurons recorded, although no information about the territory of their innervations was investigated (Invernizzi et al., 2007). Nevertheless, it is most likely that the $\mathrm{SNr}$ neurons excited by the $5-\mathrm{HT}_{2 \mathrm{C}}$ agonist Ro 60-0175 are the $\mathrm{P}(0)$-projecting neurons that responded to $\mathrm{mCPP}$ treatment (Di Giovanni et al., 2001). Consistent with these electrophysiological data, both systemic and intranigral administration of Ro 60-0175 and mCPP markedly increased extracellular GABA levels in the SNr, while glutamate levels were not affected. The stimulatory effect of systemic and local Ro 60-0175 on GABA release was dependent on the ongoing neuronal activity [tetrodotoxin (TTX) sensitive] and completely prevented by systemic administration of SB 243213. On the other hand, local application of SB 243213 into the SNr only partially blocked Ro 60-0175-induced GABA release. This suggests that the control exerted by $5-\mathrm{HT}_{2 \mathrm{C}}$ receptors on extracellular GABA in the $\mathrm{SNr}$ involves both intra- and extranigral components, such as the striatonigral pathway (Invernizzi et al., 2007). Based on our in vivo (Di Giovanni et al., 2001; Invernizzi et al., 2007) and in vitro (Rick et al., 1995; Stanford and Lacey, 1996; Gongora-Alfaro et al., 1997) evidence, it is possible to speculate that 5-HT released in vivo elicits a direct excitatory response in a discrete population of $\mathrm{SNr}$ neurons, probably resulting in the expression of $5-\mathrm{HT}_{2 \mathrm{C}}$, which in turn inhibits a greater number of neighbouring $\mathrm{SNr}$ cells through
GABA release from their extensive axon collaterals (Mailly et al., 2003; Invernizzi et al., 2007). Therefore, the source of GABA in the $\mathrm{SNr}$ might have many different origins - i.e. it might derive from a subpopulation of GABA-containing neurons in the $\mathrm{SNr}$ that are excited by $5-\mathrm{HT}_{2 \mathrm{C}}$ agonists, from release of GABA by the somatodendritic regions and their recurrent collaterals and/or from the GPe neurons excited, in turn, by the STN. We can exclude a striatal GABA source since its neurons are principally inhibited by $5-\mathrm{HT}_{2 \mathrm{C}}$ receptor agonists.

The overall effect of activation of $5-\mathrm{HT}_{2 \mathrm{C}}$ receptors, therefore, would be the overinhibition of nigrothalamic GABAergic neurons and consequent decrease of GABA levels in the motor thalamus. According to the current model of basal ganglia functional organization (DeLong, 1990), reduction of the subthalamonigral GLUergic excitatory drive and/or increase in the GABAergic inhibitory influence on nigrothalamic GABAergic neurons lead to disinhibition of thalamocortical GLUergic projections and movement initiation (Deniau and Chevalier, 1985). Thus, drugs acting at 5-HT receptors might be useful in treating akinesia and other parkinsonian symptoms characterized by an overactivity of the nigrothalamic pathway (Deniau and Chevalier, 1985; DeLong, 1990).

Strikingly, under physiological conditions, $5-\mathrm{HT}_{2 \mathrm{C}}$ receptors do not exert any tonic control on the basal ganglia activity, although blocking these receptors in the striatum leads to an increase of DA release. Indeed, there is evidence that a number of selective $5-\mathrm{HT}_{2 \mathrm{C}}$ antagonists, such as SB 200646A, SB 206553 and SB 242084, do not elicit locomotory activity, when given alone (Kennett et al., 1994, 1996, 1997). Moreover, intranigral infusion of the antagonist SB 206553 into the $\mathrm{SNr}$ on the unlesioned side of a 6-OHDAlesioned rat did not elicit a significant rotational response (Fox et al., 1998).

On the other hand, it has been shown that $5-\mathrm{HT}_{2 \mathrm{C}}$ receptor transmission may be a key determinant in the activity of $\mathrm{SNr}$ in parkinsonian basal ganglia. Accordingly, infusion of SB 206553 into the $\mathrm{SNr}$ on the 6-OHDA-lesioned side elicited a marked rotational response contraversive to 
the injection (Fox et al., 1998). Such behaviour represents a reduction in the activity of basal ganglia outputs and can be taken as representing a potential anti-parkinsonian action. Moreover, systemic administration of SB 206553 enhanced the action of $\mathrm{D}_{2}$ agonist quinpirole and $\mathrm{D}_{1}$ agonist SKF 82958 in eliciting a rotational response contraversive to the lesioned side (Fox et al., 1998; Fox and Brotchie, 2000a). The mechanism whereby $5-\mathrm{HT}_{2 \mathrm{C}}$ receptor antagonists enhance the anti-parkinsonian action of DA receptor agonists may involve reducing the overactivity of the $\mathrm{SNr}$. When given alone, $5-\mathrm{HT}_{2 \mathrm{C}}$ receptor antagonists may be capable of reducing the activity only to a certain degree following systemic administration. Therefore, there may not be a sufficient reduction in the activity of the $\mathrm{SNr}$ to restore the normal thalamocortical output and have an overt antiparkinsonian effect.

From these findings, it is clear that in the 6-OHDA PD model, the antagonists at $5-\mathrm{HT}_{2 \mathrm{C}}$ receptors show anti-parkinsonian effects and are probably decreasing $\mathrm{SNr}$ activity, an effect obtained in normal rats with the agonists instead. We explained this paradox suggesting that under pathological conditions, when the basal ganglia circuitry is impaired by DA depletion, the $5-\mathrm{HT}_{2 \mathrm{C}}$ receptor transmission is also altered. The overexpression of $5-\mathrm{HT}_{2 \mathrm{C}}$ receptors in the $\mathrm{SNr}$ could lead to a clear-cut excitatory effect on the output structures since the indirect collateral inhibition is totally overcome. Thus, the consequence is a contribution to the $\mathrm{SNr}$ overactivity that is known to be a hallmark of PD and related disorders (Di Giovanni et al., 2006b). 5- $\mathrm{HT}_{2 \mathrm{C}}$ receptor transmission may be a key determinant in the activity of the $\mathrm{SNr}$ in parkinsonian basal ganglia and its selective activation in this condition might have a surprising opposite effect compared to that which it has on the 'normal' circuitry. Studies are underway in our laboratories to verify this supposition.

In addition, the blockade of $5-\mathrm{HT}_{2 \mathrm{~A} / 2 \mathrm{C}}$ receptors is a determinant of the effect of clozapine and risperidone in inhibiting the discharge of $\mathrm{SNr}$ neurons (Bruggeman et al., 2000). Indeed, Bruggeman et al. (2000) showed that concurrent $5-\mathrm{HT}_{2 \mathrm{~A} / 2 \mathrm{C}}$ and moderate $\mathrm{DA} \mathrm{D}_{2}$ receptor anta- gonism can mimic the in vivo effects of these atypical antipsychotics on the firing rate of $\mathrm{SNr}$ neurons. Therefore, the inhibitory effect of the atypical antipsychotics clozapine and risperidone and of concurrent $5-\mathrm{HT}_{2} / \mathrm{D}_{2}$ antagonism on the $\mathrm{SNr}$ may reflect a mechanism to counteract motor side effects [extrapyramidal symptoms (EPS)] by disinhibiting thalamocortical circuits.

On the other hand, it could also be a mechanism to alleviate negative symptoms. This is based on the fact that the $\mathrm{SNr}$, aside from prominent innervations from the dorsolateral striatum, also receives afferents from the nucleus accumbens, innervating subfields of the mediodorsal and ventromedial thalamic nuclei mainly affiliated to the prelimbic area and the prefrontal cortex. Therefore, one must consider that changes in $\mathrm{SNr}$ activity may reflect not only motor activity - and in that sense EPS - but also emotional and motivational processes, which may be involved in negative symptoms.

\section{5-HT modulation of STN activity}

The STN is an important mediator of the output circuits subserving basal ganglia motor function, and a potent link between the serotonergic system, the STN and motor behaviour has been highlighted. It is interposed in the direct pathway between the external segment of the GP (GPe) and the GP (GPi)/SNr. The STN also has projections that interact with the other primary output pathway from the striatum, the direct pathway, at the level of the GPe (Kita and Kitai, 1987; Shink et al., 1996). This connectivity provides the STN with a unique ability to mediate basal ganglia motor function, and accordingly, the STN has a strong influence on motor behaviour related to basal ganglia DAergic neurotransmission. For instance, the STN has been implicated in the mediation of parkinsonian movement disorders. An increase in the basal activity of the excitatory GLUergic afferent neurons of the STN, associated with the loss of DA terminals in the striatum, may play a role in the hypokinetic symptoms of this condition (Smith and Grace, 1992). Indeed, STN lesion, as well as its inactivation by deep brain stimulation (DBS), has shown to have anti-parkinsonian 
effects in an experimental primate model of PD and in PD patients (Krack et al., 1998; Charles et al., 2004; Sturman et al., 2004). Under normal DA function, in both humans and primates, unilateral lesions of the STN result in hemiballism and chorea, which are characterized by involuntary, hyperkinetic movements of the contralateral limbs (Mitchell et al., 1985; Bhidayasiri and Truong, 2004). During the past decade, patients suffering from PD have undergone modulation of this STN hyperactivity by highfrequency stimulation (HFS) (Limousin et al., 1995). HFS of the STN has dramatic therapeutic effects on locomotor symptoms (Krack et al., 2003). The mechanism by which STN HFS improves locomotor symptoms is not well understood, but some evidence suggests that HFS modulates the pathological activity within the STN (Garcia et al., 2005), lowering GABA release in the motor thalamus (Stefani et al., 2006).

On the other hand, it is known that 5-HT neurons, mainly from the DRN, innervate the STN and clearly modulate its neuronal activity. 5-HT may have multiple actions in the STN. Whole-cell patch-clamp and extracellular singleunit recordings on rat brain slices with selective 5-HT agonists and antagonists indicated both $5-\mathrm{HT}_{1 \mathrm{~A}}$ receptor-mediated inhibitory and $5-\mathrm{HT}_{2 \mathrm{C}}$ and $5-\mathrm{HT}_{4}$ receptor-mediated excitatory responses of 5-HT in subthalamic neurons (Stanford et al., 2005; Shen et al., 2007). In addition, 5-HT inhibits synaptic transmission in the STN by activating presynaptic $5-\mathrm{HT}_{1 \mathrm{~B}}$ receptors. Indeed, in a recent electrophysiological study in slices of rat brain, 5-HT reduced the amplitude of both GLUergic excitatory postsynaptic currents (EPSCs) and GABAergic inhibitory postsynaptic currents (IPSCs) on the STN neuron membrane (Shen and Johnson, 2008). The 5-HT-induced inhibition of synaptic currents was associated with a significant increase in the paired-pulse ratios of evoked EPSCs and IPSCs, suggesting that 5-HT acts presynaptically to suppress both GLU and GABA release. However, 5-HT was more potent for reducing EPSCs compared to IPSCs (Shen and Johnson, 2008). This inhibitory effect was mediated via the activation of $5-\mathrm{HT}_{1 \mathrm{~B}}$ receptors because selective $5-\mathrm{HT}_{1 \mathrm{~B}}$ antagonists blocked
5-HT-induced inhibition of EPSCs and IPSCs (Shen and Johnson, 2008). Consistent with its presynaptic location, 5- $\mathrm{HT}_{1 \mathrm{~B}}$ receptor activation has been shown to cause presynaptic inhibition of GABA-mediated transmission in the SN also (Johnson et al., 1992; Stanford and Lacey, 1996). According to a widely used model of basal ganglia function, a reduction in excitatory glutamate input to the STN would be expected to improve the symptoms of PD (Bonsi et al., 2007b). Indeed, injection of $5-\mathrm{HT}_{1 \mathrm{~B}}$ agonists systemically (Oberlander et al., 1987; Rempel et al., 1993) or into the STN (Martinez-Price and Geyer, 2002) has been reported to increase locomotion in rats. However, 5- $\mathrm{HT}_{1 \mathrm{~B}}$ receptor stimulation has also been reported to reduce L-DOPA-induced dyskinesia (LID) in a rat model of PD (Carta et al., 2007), which is not what one would predict based on inhibition of excitatory input to the STN. Moreover, 5- $\mathrm{HT}_{1 \mathrm{~B}}$ agonists have also been reported to interfere with the benefit of L-DOPA in a marmoset model of PD. Activation of $5-\mathrm{HT}_{1 \mathrm{~B} / 1 \mathrm{D}}$ receptors induced motor deficits and inhibited motor responses to L-DOPA, whereas blockade of $5-\mathrm{HT}_{1 \mathrm{~B}}$ receptors had no observable effects on motor behaviours (Jackson et al., 2004). These data suggest that neither stimulation nor blockade of $5-\mathrm{HT}_{1 \mathrm{~B}}$ receptors will be therapeutically beneficial to the treatment of PD or drug-induced dyskinetic syndromes.

The $5-\mathrm{HT}_{2 \mathrm{C}}$ receptors are most likely to be involved in 5-HT effects since they are present in a relatively high concentration in this nucleus. The most frequent response to 5 -HT seems to be an excitation of STN neurons (Flores et al., 1995; Stanford et al., 2005; Xiang et al., 2005; Shen et al., 2007). This effect is mediated by the activation of the $5-\mathrm{HT}_{2 \mathrm{C}}$ and $5-\mathrm{HT}_{4}$ receptors being reversed by the combined use of selective antagonists for 5- $\mathrm{HT}_{4}$ and $5-\mathrm{HT}_{2 \mathrm{C}}$ receptors (Stanford et al., 2005; Xiang et al., 2005). In addition, Shen et al. (2007) found that STN neuron burst firing was facilitated by $5 \mathrm{HT}_{2 \mathrm{C}^{-}}$and $5 \mathrm{HT}_{4}$-dependent currents, and since excessive burst firing of STN neurons has been implicated in the expression of the symptoms of $\mathrm{PD}$, it was suggested that antagonists at $5 \mathrm{HT}_{2 \mathrm{C}}$ or $5 \mathrm{HT}_{4}$ receptors might be useful in the treatment of PD. Moreover, an 
inhibitory action of 5-HT over a small subpopulation (about 20\%) of STN neurons has been also shown (Stanford et al., 2005, Shen et al., 2007), and it seems to be mediated by $5-\mathrm{HT}_{1 \mathrm{~A}}$ receptor activation (Stanford et al., 2005). Thus, this electrophysiological evidence indicates that 5-HT-induced excitation and inhibition in the STN are separate entities and most likely to arise as a consequence of independent, direct postsynaptic effects mediated by $5-\mathrm{HT}_{2} \mathrm{C}, 5-\mathrm{HT}_{4}$ and 5$\mathrm{HT}_{1 \mathrm{~A}}$ subtypes. The excitatory 5-HT effect through the activation of $5-\mathrm{HT}_{2 \mathrm{C}}$ receptors is in accordance with the results of a recent study that investigated the effect of subthalamic DBS, using clinically relevant stimulation parameters, on DOI-induced hypomobility (Hameleers et al., 2007). These authors found that administration of DOI decreased the locomotor activity, as evidenced by a net decrease in the distance moved, the velocity and the time spent in moving. This decrease in locomotion was reversed by DBS of the STN. Varying results of DOI administration on locomotion have been obtained in the past. Some studies showed an increase in locomotor activity after DOI administration (Darmani et al., 1996; Granoff and Ashby, 1998); some authors found no effects (Hawkins et al., 2002), and others demonstrated hypomobility in rats treated with DOI (Krebs-Thomson and Geyer, 1996). It is probably the concentration of DOI that is contributing to the difference in these studies. In their study, Xiang et al. (2005) found a clear reduction of locomotor activity, which was reversed by STN HFS. It is known that injection of 5- $\mathrm{HT}_{2 \mathrm{~A}}$ and 5$\mathrm{HT}_{2 \mathrm{C}}$ agonists can increase the firing rate of STN neurons (Xiang et al., 2005). Since DOI activates these receptors, it is likely that DOI excites STN neurons and induces increased STN activity. Increased STN activity is thought to be responsible for the hypokinesia in PD. In addition, these findings support the hypothesis that $5-\mathrm{HT}_{2}$ receptors may mediate the therapeutic effects of STN HFS on locomotor symptoms.

However, this evidence is not in accordance with a large body of behavioural evidence that shows an inhibitory action of 5-HT over the STN by acting on $5-\mathrm{HT}_{2 \mathrm{C}}$ receptors. As a result, a decrease in the excitatory input from the $\mathrm{STN}$ to $\mathrm{GPe} / \mathrm{SNr}$ occurs, which in turn enhances the activity of the ipsilateral motor thalamus. Indeed, the unilateral injection of 5-HT into the STN induces a contralateral dose-dependent turning behaviour, which is blocked by the unselective $5-\mathrm{HT}_{2}$ antagonist mianserin. The contribution of the $5-\mathrm{HT}_{2 \mathrm{C}}$ receptor in 5-HT-induced behaviour was revealed by the intrasubthalamic injection of the $5-\mathrm{HT}_{2 \mathrm{C}}$ receptor agonist MK 212 that, in concordance, increased the net turns (Belforte and Pazo, 2004). In addition, the blockade of subthalamic $5-\mathrm{HT}_{2 \mathrm{C}}$ receptors suppressed the stereotypic behaviour induced by apomorphine administration (Barwick et al., 2000) while both systemic administration and local unilateral infusion of mCPP into the STN induced an increase in oral movements in rats (Eberle-Wang et al., 1996; De Deurwaerdere and Chesselet, 2000; Mehta et al., 2001) that resemble the orofacial dyskinesias occurring as a severe side effect of prolonged treatment with antipsychotic drugs in humans (Waddington et al., 1986; Ellison, 1991). Oral dyskinesia observed after peripheral injections of mCPP was enhanced by 5,7-DHTinduced lesion of the serotonergic neurons, probably due to an altered sensitivity to $5-\mathrm{HT}_{2 \mathrm{C}}$ receptor stimulation in the STN (Mehta et al., 2001). Interestingly, these authors observed mCPP-induced seizure-like behaviours in a subset of lesioned rats that were never observed in shamlesioned animals, thus demonstrating a pivotal role for the 5- $\mathrm{HT}_{2 \mathrm{C}}$ receptor in the control of the normal neuronal excitability, a phenomenon already noted by others (Mehta et al., 2001). Despite the fact that the mechanism by which serotonergic inputs to the STN contribute to its normal functioning remains controversial, the behavioural data discussed above clearly suggest that excess stimulation of $5-\mathrm{HT}_{2 \mathrm{C}}$ receptors in this region may lead to hyperkinetic movement disorders. Thus, $5-\mathrm{HT}_{2 \mathrm{C}}$ antagonists can be useful to treat the side effects of long-term administration of neuroleptics in schizophrenia (Tarsy and Baldessarini, 1984; Reynolds, 2004). Serotonergic projections from the DRN and the MRN innervate all components of the basal ganglia circuitry; thus, there is evidence that endogenous 5-HT induces excitations of the STN neurons through several types of 5-HT receptors (Belforte and 
Pazo, 2004; Stanford et al., 2005; Xiang et al., 2005). Since this nucleus is considered to be a major driving force in the basal ganglia circuit (Albin et al., 1989; Utter and Basso, 2008), it is important to understand the role of the various 5-HT receptor subtypes in the control of this area. With regard to the other 5-HT receptors, besides $5-\mathrm{HT}_{1 \mathrm{~A}}, 5-\mathrm{HT}_{1 \mathrm{~B}}, 5-\mathrm{HT}_{2 \mathrm{~A}}$ and $5-\mathrm{HT}_{2 \mathrm{C}}$, there is evidence that only the $5-\mathrm{HT}_{3}$ and $5-\mathrm{HT}_{4}$ receptors are involved in the control of the subthalamic neurons. Unilateral injection of 5-HT into the STN induced a contralateral dose-dependent turning behaviour, attributed to a decreased excitatory input from the STN to the SNr, which in turn enhanced the activity of the ipsilateral motor thalamus (Belforte and Pazo, 2004). Similar results were also observed with microinjections of quipazine, a mixed 5- $\mathrm{HT}_{2 \mathrm{~B} / 2 \mathrm{C} / 3}$ agonist, MK 212, a $5-\mathrm{HT}_{2 \mathrm{~B} / 2 \mathrm{C}}$ agonist, and $\mathrm{m}$-chlorophenylbiguanidine, a 5- $\mathrm{HT}_{3}$ agonist (Belforte and Pazo, 2004). Furthermore, kainic acid lesion of the $\mathrm{SNr}$ suppressed the contralateral rotations elicited by the stimulation of $5-\mathrm{HT}_{2 \mathrm{~B} / 2 \mathrm{C}}$ and $5-\mathrm{HT}_{3}$ subthalamic receptors (Belforte and Pazo, 2004). Taken together, these data suggest that 5-HT tonically stimulates the subthalamonigral pathway, through $5-\mathrm{HT}_{2 \mathrm{C}}$ and $5-\mathrm{HT}_{3}$ receptor subtypes, without involving the DAergic innervation of the nucleus, because stimulation of subthalamic 5-HT receptors in animals bearing a lesion of the nigrostriatal pathway did not modify this motor response (Belforte and Pazo, 2004).

The stimulating action of 5-HT on the STN is further confirmed by electrophysiological investigations. Endogenous application of 5-HT in mouse and rat brain slices increased the firing frequency of subthalamic neurons (Flores et al., 1995; Stanford et al., 2005; Xiang et al., 2005).

The increased firing rate of these neurons was attributed to the depolarization of membrane potential caused by a reduction of potassium conductance mediated by $5-\mathrm{HT}_{2 \mathrm{C}}$ and mainly by $5-\mathrm{HT}_{4}$ receptor subtypes (Stanford et al., 2005; Xiang et al., 2005). Using several serotonergic agonists and antagonists, Xiang et al. (2005) found that only $\alpha$-methyl-5-HT, a $5-\mathrm{HT}_{2}$ agonist with good affinity for $5-\mathrm{HT}_{4}$ receptors, and cisapride, a $5-\mathrm{HT}_{4}$ agonist, mimicked the action of 5-HT.
Furthermore, the 5-HT action was partially reversed by the 5- $\mathrm{HT}_{4}$ antagonist SB 23597-190, the $5-\mathrm{HT}_{2}$ antagonist ketanserin and the $5-\mathrm{HT}_{2 \mathrm{C}}$ receptor antagonist RS 102221; in addition, the effect of RS 102221 was comparable with that of ketanserin. Therefore, it was concluded that $5-\mathrm{HT}_{4}$ and $5-\mathrm{HT}_{2 \mathrm{C}}$ receptor subtypes are involved in the excitatory action of 5-HT in STN neurons and may be co-localized in a single neuron (Xiang et al., 2005). These data were replicated by Stanford et al. (2005), who showed that the preinfusion of RS 102221 and GR 113808, another $5-\mathrm{HT}_{4}$ antagonist, reduced excitations of STN neurons induced by local application of 5-HT. On the basis of these results, it was concluded that when there is the cortical activation for a specific movement, a group of raphe serotonergic neurons that project to the STN and STN neurons themselves might be simultaneously activated, then amplify subthalamic activity and consequently facilitate the excitation of the output structures in the basal ganglia, which in turn inhibits the thalamic motor area (Xiang et al., 2005). In the classical rate model of basal ganglia function, the neural mechanisms underlying the generation of parkinsonian symptoms are thought to involve reduced activation of primary motor and premotor cortex, and supplementary motor areas secondary to an over-activation of the output regions of the basal ganglia, i.e. $\mathrm{SNr}$ and GPi (Albin et al., 1989), largely because of excessive excitatory drive from the STN, consequent to DA loss in the striatum (Nicholson and Brotchie, 2002; Utter and Basso, 2008). Hence, it is theoretically possible that antagonists at the $5-\mathrm{HT}_{2 \mathrm{C}}$ and $5-\mathrm{HT}_{4}$ receptors, which act directly to reduce STN neural activity, may have positive therapeutic benefits in PD.

\section{5-HT modulation of GP activity}

Anatomical and experimental evidence supports a pivotal role for 5-HT in the control of neuronal activity of both the GPe and the GPi, which express several 5-HT receptors. Perkins and Stone (1983) found that typical high-frequency firing GPe neurons in anaesthetized rats were not responsive to iontophoretically applied 5-HT, and 
5-HT inhibited a small number of low-frequency firing GPe neurons. In contrast, Querejeta et al. (2005) found that local application of a 5-HT receptor agonist, or fluoxetine, excites most of the GPe neurons in anaesthetized rats, showing the presence of a serotonergic excitatory tone on GP neurons. This evidence was further confirmed by a recent patch-clamp recording study (Chen et al., 2008). In reality, the effect of 5-HT is more complex because of the existence of various receptor subtypes on presynaptic and postsynaptic membranes in the pallidum. In fact, recent electrophysiological evidence has shown that 5-HT exerts strong modulation on inhibitory and excitatory responses to cortical stimulation in the GPe and the GPi (Kita et al., 2007; Hashimoto and Kita, 2008). 5-HT suppressed GABAergic inhibitory responses to cortical stimulation in monkeys, through presynaptic $5-\mathrm{HT}_{1 \mathrm{~B}}$ receptors, densely expressed on axons and axon terminals in the pallidum (Kita et al., 2007). On the other hand, $5-\mathrm{HT}_{1 \mathrm{~A}}$ receptors are involved in the suppression of GLUergic excitations of the GP because local application of WAY 100635, a 5- $\mathrm{HT}_{1 \mathrm{~A}}$ selective antagonist, blocked the effect of subsequent applications of 5-carboxamindotryptamine (5-CT) in suppressing cortical stimulation-induced excitations (Kita et al., 2007). Hence, 5-HT may reduce ionotropic GLUergic excitation, probably through $5-\mathrm{HT}_{1 \mathrm{~A}}$ receptors located at presynaptic and/or postsynaptic sites. On pallidal neuron slices, 5-HT and 5-CT presynaptically reduce glutamate release in the GPe, and the antagonistic effect of GR 55562 suggested an involvement of $5-\mathrm{HT}_{1 \mathrm{~B} / 1 \mathrm{D}}$ receptors in this effect (Hashimoto and Kita, 2008).

In accordance with these findings, an in vivo electrophysiological study reported that local application of the 5- $\mathrm{HT}_{1 \mathrm{~B}}$ receptor agonist L-694247 excited most GPe neurons, which can be due to presynaptic suppression of GABAergic inhibitions, in anaesthetized rats (Querejeta et al., 2005). In addition, the effect of 5-HT in the electrical activity of GP neurons of rats with unilateral quinolinic acid striatal lesions was severely attenuated, indicating that presynaptic $5-\mathrm{HT}_{1 \mathrm{~B}}$ receptors modulate GABA release from striatopallidal terminals (Querejeta et al., 2005). Taken together, these data indicate that the tonic activation of 5- $\mathrm{HT}_{1 \mathrm{~B}}$ receptors significantly contributes to the decrease of GABA release from striatopallidal GABAergic terminals facilitating GP neurons' spiking; on the other hand, the blockade of these receptors causes a significant decrease on the spiking frequency of GP neurons due to the augmented GABA release from striatopallidal terminals (Querejeta et al., 2005). In line with these studies, $5 \mathrm{HT}_{1 \mathrm{~B}}$ receptor activation with CP-93129 inhibited the release of $\left[{ }^{3} \mathrm{H}\right]-\mathrm{GABA}$ from pallidal slices, and intrapallidal injection of CP-93129 alleviated akinesia in the reserpine-treated rat model of $\mathrm{PD}$, indicating that some $5 \mathrm{HT}_{1 \mathrm{~B}}$ receptors can function as heteroreceptors in the GP, reducing the release of GABA from striatopallidal neurons. This cellular mechanism underlies the anti-akinetic activity of CP-93129 seen in the reserpine-treated rat model of PD (Chadha et al., 2000).

The application of 5-HT into the superfusion medium of brain slices containing GP neurons directly stimulated the receptors of the recorded neurons and produced a reversible depolarization of their membrane that consequently increased the firing rate of these neurons (Chen et al., 2008). 5-HT postsynaptic excitation of pallidal neurons occurs through activation of $5-\mathrm{HT}_{4}$ or $5-\mathrm{HT}_{7}$ receptors but not via $5-\mathrm{HT}_{2 \mathrm{C}}$ and $5-\mathrm{HT}_{3}$ receptors (Bengtson et al., 2004; Kita et al., 2007; Chen et al., 2008; Hashimoto and Kita, 2008).

These findings support the hypothesis that the increase of 5-HT tone, which mainly excites pallidal neurons directly and counteracts the inhibition from the striatum selectively, will exert an anti-parkinsonian effect.

\section{5-HT in PD and other motor disorders}

\section{Parkinson's disease}

PD is the second most common neurodegenerative disease in the elderly population with an inevitable exitus. The idiopathic form is a progressive disorder, the impact of which reaches far beyond the clinical signs and symptoms exhibited by those afflicted. Clinical features at presentation include the asymmetric onset of cardinal motor symptoms 
such as tremor at rest, bradykinesia, muscular rigidity, stooped posture and instability (Sian et al., 1999).

Since Hornykiewicz's pioneering work in identifying the $\mathrm{SNc}$ as the site of major pathological change in $\mathrm{PD}$, reduced DAergic innervation of the striatum has been thought to be central to its pathogenesis (Hornykiewicz, 1973). Hitherto, the underlying mechanisms of neuronal loss in patients are not known. Therefore, current therapies work mainly to alleviate symptoms rather than to halt the progression of the disease (Di Giovanni, 2008). There have been major advances in understanding the aetiopathogenesis of PD and the modalities whereby the neurodegenerative process begins and progresses; therefore, the development of drugs to slow and halt DAergic neuronal degeneration or even to prevent the disease now seems realistic (Esposito et al., 2007a, b, c; Di Giovanni, 2008).

The modulation of 5-HT of the basal ganglia nuclei has obvious implications for the treatment of a range of motor diseases, most notably including PD, LID and antipsychotic-induced extrapyramidal effects. It has become axiomatic that manipulation of 5-HT transmission may be pivotal in treating the symptoms and of key importance in improving symptomatologies in this patient set (Nicholson and Brotchie, 2002; Di Giovanni et al., 2006a, b; Scholtissen, et al., 2006).

Although 5-HT involvement in PD has long since been known (Scatton et al., 1983; Miyawaki et al., 1997), the neuropathological literature on the status of the DRN in PD is not entirely clear. In fact, both loss of 5-HT cells bodies and no modification in their number in PD have been reported (Sawada et al., 1985; Jellinger, 1987; Halliday et al., 1990; Paulus and Jellinger, 1991; Kim et al., 2003). Notwithstanding, in primates, surgical lesion of upper brain stem producing contralateral resting tremor and bradykinesia were associated with reduced homolateral striatal 5-HT (Goldstein et al., 1969). Compelling evidence instead exists about damage of the ascending pathways limited to the nerve terminal of 5-HT neurons in different brain regions of PD patients (Chase and Ng, 1972; Chase, 1974; Chinaglia et al., 1993). Indeed, postmortem examinations have shown a reduction of up to $50 \%$ of $5-\mathrm{HT}$ in some areas of the cortex and the basal ganglia (Scatton et al., 1983; Birkmayer and Riederer 1986; Birkmayer and Birkmayer, 1987). Unlike the preferential loss of DA in the putamen, the caudate is affected more than the putamen by loss of all 5-HT markers: 5-HT (-66\%), 5-hydroxyindolacetic acid (5-HIAA; the major 5-HT metabolite) $(-42 \%), \quad 5-\mathrm{HT}$ transporter (5-HTT) $(-56 \%)$ and tryptophan hydroxylase (TPH; the marker synthetic enzyme) (-59\%) (Kish et al., 2008). Reduced brain levels of all of the key markers for the 5-HT neurotransmitter system provide compelling evidence for a striatal serotonergic abnormality in PD. This evidence has been confirmed by antemortem studies and imaging investigations that showed reduced cerebrospinal fluid levels of 5-HIAA and decreased activity of 5-HTT not only in the caudate nucleus and the putamen but also in the thalamus and medial frontal areas, indicating a pathophysiological involvement of 5-HT in PD (Haapaniemi et al., 2001; Kerenyi et al., 2003; Kim et al., 2003). It is, however, very likely that the degree of serotonergic degeneration depends on the stage of the disease (Scholtissen et al., 2006). Nevertheless, Bjorklund's group recently showed that serotonergic innervation of the striatal complex remains relatively intact in most PD patients (Carta et al., 2007).

\section{5-HT receptors' expression in PD animal models and in patients}

Animal models are important tools in experimental medical science to better understand the pathogenesis of human diseases such as PD. However, preclinical research on these animal models has provided inconsistent results, highlighting that these experimental models represent only an imperfect replica of human disorders (Scholtissen et al., 2006).

The first PD animal model developed is the 6-OHDA; this agent selectively disrupts catecholaminergic systems and reproduces specific features of PD in rodents, apparently via oxidative damage (Simola et al., 2007 and references therein). 
6-OHDA-lesioned animals have been exploited to test therapeutic approaches for treating functional disturbances observed in this disease and will aid the future development of rational therapeutic strategies. The 6-OHDA lesion can be performed in adult or neonatal rats, producing different changes in behaviour and the neurochemistry of these animals, according to the age of the lesion (Breese et al., 2005).

Although independently of the age in which the SNc is injured, 6-OHDA leads to permanent DA ablation while the serotonergic projection to the striatum remains intact. Contrasting results of the activity of DRN serotonergic neurons in 6-OHDA-lesioned rats exist; an increase in frequency and burst firing activity (Chu et al., 2004; Zhang et al., 2007) or a decrease $(-60 \%)$ of discharge rate (Guiard et al., 2008) has actually been reported.

Both neonatal and adult lesions actually lead to a 5-HT axonal hyperinnervation within the dorsal striatum (Stachowiak et al., 1984; Breese et al., 1985; Zhou et al., 1991; Molina-Holgado et al., 1994; Mrini et al., 1995; Balcioglu et al., 2003; Maeda et al., 2003). Consistently, striatal 5-HT levels and 5-HTT binding have been reported to be increased in this animal model of PD (Commins et al., 1989; Zhou et al., 1991; Guerra et al., 1997; Mendlin et al., 1999; Balcioglu et al., 2003). Interestingly, it has been proposed that striatal 'reactive' serotonergic hyperinnervation in lesioned animals occurs to compensate for the lost function of DAergic terminals and this might 'mask' the true extent of the 5-HT loss in PD.

This suggests that 5-HT neurotransmission is impaired and the clarification of the pathophysiological mechanism can provide unique information regarding the treatment of parkinsonism from a point of view that differs from conventional therapy.

In addition to DA depletion, a discrete modification in the regulation of postsynaptic 5-HT receptors in different areas of the basal ganglia circuitry and in other brain areas has been observed in animals and humans (Kienzl et al., 1981; Radja et al., 1993). Therefore, alterations of 5-HT binding constants in PD might reflect an imbalance in serotonergic activity.
5- $\mathrm{HT}_{1 \mathrm{~A}}$ binding is not altered in the basal ganglia nuclei of neonatally 6-OHDA-lesioned rats. In contrast, there is a considerable increase in binding for $5-\mathrm{HT}_{1 \mathrm{~B}}$ receptors. The highest increase of $5-\mathrm{HT}_{1 \mathrm{~B}}$ binding sites is observed in the $\mathrm{SN}(54 \%)$, the GP (33\%) and the two portions of neostriatum. The most likely explanation for the present increases in the neostriatal, nigral and pallidal regions is therefore an augmented production (up-regulation) of these receptors by the neostriatal projection neurons and concomitant increase of their axonal transport to both territories of projection. In view of its widespread distribution in the neostriatum, it also seemed likely that the neostriatal increase in $5-\mathrm{HT}_{1 \mathrm{~B}}$ binding was somehow related to the DA denervation of this brain region rather than to its subsequent 5-HT hyperinnervation, suggesting a possible role for DA in the regulation of 5-HT receptor expression during ontogenesis. A significant increase in the density of $5-\mathrm{HT}_{2 \mathrm{C}}$ was also revealed throughout the neostriatum $(40 \%)$ and in the SN $(50 \%)$, but unchanged in the GP, as if this up-regulation preferentially involved striatonigral as opposed to striatopallidal neurons (Radja et al., 1993).

Consistently, enhanced responses of spontaneously firing units to iontophoresed 5-HT and both $5-\mathrm{HT}_{2 \mathrm{C}}$ and $5-\mathrm{HT}_{2 \mathrm{~A}}$ agonists have been demonstrated in the 5-HT-hyperinnervated neostriatum after neonatal 6-OHDA lesion (el Mansari et al., 1994). 5- $\mathrm{HT}_{2 \mathrm{~A}}$ binding showed an even greater increase $(60 \%)$, which was restricted to the rostral half of the neostriatum and also seemed imputable to an up-regulation as heteroreceptors. $5-\mathrm{HT}_{2 \mathrm{~A}}$ receptor expression increases significantly on direct pathway neurons (Laprade et al., 1996; Basura and Walker, 1999), even though $5-\mathrm{HT}_{2 \mathrm{~A}}$ receptors are expressed on both direct and indirect striatal projecting neurons (Ward and Dorsa, 1996).

The intracellular mechanisms that mediate the effects of 5-HT within the neonatal lesioned striatum are poorly understood. Neonatal lesions result in altered expression of preprotachykinin (decrease) and preproenkephalin (increase) in direct and indirect striatal pathway neurons, 
respectively (Sivam et al., 1987). It has been shown that 5-HT acting via 5- $\mathrm{HT}_{2}$ receptors could regulate preprotachykinin expression selectively in direct pathway neurons and ultimately motor function, after neonatal DA depletion (Basura and Walker, 2001). Recently, it has been shown that neonatal but not adult 6-OHDA lesions result in a novel coupling of $5-\mathrm{HT}_{2 \mathrm{~A}}$ receptors to the ERK1/2/MAP kinase pathway, a signalling cascade known to regulate neuronal plasticity that is not typically active in these neurons. Because DA-mediated signalling is redundant after 6-OHDA lesions, 5-HT-mediated stimulation of the ERK1/2/MAP kinase pathway may provide an alternative signalling route allowing the regulation of neuronal gene expression and neuronal plasticity in the absence of DA (Brown and Gerfen, 2006).

In adult rats, destruction of the nigrostriatal DA projection by 6-OHDA has not been found to modify $\left[{ }^{3} \mathrm{H}\right] 5-\mathrm{HT}$ binding in the neostriatum (Quirion and Richard, 1987).

Consistently, in situ hybridization and autoradiographic radioligand studies from lesioned rats and human postmortem tissue from patients with PD have revealed that striatal $5-\mathrm{HT}_{1 \mathrm{~A}}$ (Numan et al., 1995) and 5-HT ${ }_{1 \mathrm{~B}}$ (Zhang et al., 2008) are not influenced by DA depletion. In the striatum, $5-\mathrm{HT}_{2 \mathrm{~A}}$ receptors appear to be up-regulated (Numan et al., 1995) and 5- $\mathrm{HT}_{2 \mathrm{C}}$ receptors down-regulated (Numan et al., 1995; Zhang et al., 2007) or not affected (Basura and Walker, 1999; Fox and Brotchie, 2000b). Striatal 5- $\mathrm{HT}_{2 \mathrm{~A}}$ and $5-\mathrm{HT}_{2 \mathrm{C}}$ are therefore differently regulated in 6-OHDA-lesioned animals. There is no significant difference in $5-\mathrm{HT}_{2 \mathrm{C}}$ binding level for control vs. PD tissue in the GPi and the GPe (Fox and Brotchie, 2000b), and in the levels of $5-\mathrm{HT}_{2 \mathrm{C}}$ mRNA between the intact and 6-OHDA-lesioned hemispheres in the nucleus subthalamicus in rats (Zhang et al., 2007). Conversely, 50\% increase in $5-\mathrm{HT}_{2 \mathrm{C}}$ receptor binding was observed in 6-OHDA-lesioned rats, strictly in accordance with the evidence that $5-\mathrm{HT}_{2 \mathrm{C}}$ receptor binding in the $\mathrm{SNr}$ of age-matched control tissue was less than half that in the $\mathrm{SNr}$ of patients with PD (Radja et al., 1993; Fox and Brotchie, 2000b).
This evidence highlights a selective change in the $5-\mathrm{HT}_{2 \mathrm{C}}$ receptor activity only in the output regions of the basal ganglia. $5-\mathrm{HT}_{2 \mathrm{C}}$ receptors' up-regulation might be compensatory, being a consequence of a decreased level of 5-HT in these nuclei, thus indicating a role for them in the neuronal mechanisms involved in PD (Fox and Brotchie, 2000b).

It is noteworthy that L-DOPA/benserazide treatment not only reversed the 6-OHDA-induced levels of $5-\mathrm{HT}_{2 \mathrm{~A}} \mathrm{mRNA}$ in the striatum but also caused a highly significant reduction in the levels of this receptor. In contrast, $5-\mathrm{HT}_{2 \mathrm{C}}$ mRNA was not affected by L-DOPA/benserazide treatment (Zhang et al., 2007). It can be concluded from these findings that the regulation of $5-\mathrm{HT}_{2 \mathrm{~A}}$ is highly dependent on alterations in DA levels. In contrast, striatal $5-\mathrm{HT}_{2 \mathrm{C}}$ appears to be regulated by nigrostriatal cell loss and the reduced level(s) of factor(s), other than DA, such as brain-derived neurotrophic factor (BDNF) and cholecystokinin, which are normally expressed in nigrostriatal neurons. Similarly, numerous studies conducted in patients with PD and in animal models of this disease, such as 6-OHDA-lesioned rats and MPTP-treated primates, have shown that L-DOPA-treatment does not adequately reverse the effects of DA cell loss but rather creates a new functional and neurochemical state, which differs both from the normal and lesioned states (Bezard et al., 2003). The fact that 5- $\mathrm{HT}_{2 \mathrm{~A}}$, but not $5-\mathrm{HT}_{2 \mathrm{C}}$, receptors are responsive to L-DOPA treatment predicts that pharmacological manipulations at $5-\mathrm{HT}_{2 \mathrm{C}}$, but not at $5-\mathrm{HT}_{2 \mathrm{~A}}$, will result in similar effects in PD patients whether they are treated or not with DA replacement. These data therefore support the notion that $5-\mathrm{HT}_{2 \mathrm{C}}$ receptor antagonists may be useful as an adjuvant treatment to DA agonists to treat motor complications of PD (Fox et al., 1998; Di Giovanni et al., 2006a; Zhang et al., 2007).

Consistent with these findings, systemic administration of the selective $5-\mathrm{HT}_{2 \mathrm{C}}$ antagonist $\mathrm{SB}$ 206553 was shown to enhance the action of the anti-parkinsonian action of the DA $\mathrm{D}_{1}$ and $\mathrm{D}_{2}$ agonists in 6-OHDA-lesioned rats (Fox et al., 1998; Fox and Brotchie, 2000a), suggesting that the use of 
a $5-\mathrm{HT}_{2 \mathrm{C}}$ receptor antagonist in combination with a DA receptor agonist may reduce the reliance upon DA replacement therapies. Hitherto, no studies have been conducted in either non-human primates or humans to address this issue.

$5-\mathrm{HT}_{3}$ binding is reduced in the entorhinal and prefrontal cortices on the 6-OHDA-lesioned side of the rat brain while no changes in the amygdala and the hippocampus were observed (Cicin-Sain and Jenner, 1993). Unfortunately, these authors did not measure the $5-\mathrm{HT}_{3}$ binding in the basal ganglia. Nevertheless, it has been suggested that the $5-\mathrm{HT}_{3}$ blockade might be important in the effect of the anti-parkinsonian agent talipexole (Nishio et al., 1996).

No modification of the distribution and density of $5-\mathrm{HT}_{4}$ receptor binding sites was observed in 6-OHDA-lesioned guinea pig basal ganglia neither in the caudate-putamen nor in the SN itself (Vilaro et al., 2005). On the other hand, following lesion of DA neurons by intranigral injection of 6-OHDA, an increased 5- $\mathrm{HT}_{4}$ receptor binding was instead observed in the caudal $(59 \%)$, but not the rostral, part of the caudate-putamen as well as in the GP (93\%) (Compan et al., 1996). Since no decreases in $5-\mathrm{HT}_{4}$ receptor density have been detected in both studies (Compan et al., 1996; Vilaro et al., 2005) after the DA lesion, it is likely that these receptors are not expressed in DA neurons but are located on terminals of striatal projection neurons. Kainic acid lesions of the caudate-putamen were associated with dramatic local decreases in $5-\mathrm{HT}_{4}$ receptor binding on the injected side $(-89 \%)$, which suggested that striatal neurons expressed $5-\mathrm{HT}_{4}$ receptors. Corresponding decreases of 72 and $20 \%$ in receptor density were detected in the GP and the $\mathrm{SN}$, consistent with a presumed localization of $5-\mathrm{HT}_{4}$ receptors on striatal GABA neurons projecting to these regions. In the $\mathrm{SN}$, the decrease in $\left[{ }^{3} \mathrm{H}\right] \mathrm{GR} 113808$ binding was localized to the pars lateralis, indicating that striatal neurons belonging to the corticostriato-nigro-tectal pathway and containing GABA and dynorphin express $5-\mathrm{HT}_{4}$ receptors. As yet, no experimental evidence has been found about the modification in expression of $5-\mathrm{HT}_{5}$, $5-\mathrm{HT}_{6}$ and $5-\mathrm{HT}_{7}$ receptors in the basal ganglia of an animal model of PD.

\section{Role of 5-HT in LID}

The abnormal involuntary movements, or dyskinesia, generated by prolonged administration of L-DOPA represent one of the major challenges facing current therapy for PD. These debilitating motor disturbances are all the more problematic because L-DOPA, in spite of its introduction several decades ago, still represents the therapy of choice for the treatment of PD. The discovery of pharmacological interventions able to counteract LID would therefore represent an important breakthrough in the therapy for PD. The design of novel agents for the prevention and treatment of LID requires the elucidation of the adaptive changes produced in the parkinsonian brain by repeated administration of L-DOPA and the assessment of their role in the development and expression of this condition. Recently, compelling evidence has been produced about the causative role of 5-HT in LID developing in both animal models and PD patients, suggesting a use of serotonergic agents in reducing LID in PD patients (Jackson et al., 2004; Johnston and Brotchie, 2006; Carlsson et al., 2007; Carta et al., 2007). In fact, 5-HT neurons have been shown to be able to convert exogenous L-DOPA to DA, and store and release DA in an activity-dependent manner but without the fine control that occurs in DA release by DA neurons (see Chapter 22). Therefore, activation of the autoreceptors 5- $\mathrm{HT}_{1 \mathrm{~A}}$ and $5-\mathrm{HT}_{1 \mathrm{~B}}$, localized on the soma and terminals of 5-HT neurons, respectively, has been shown to be highly effective in counteracting LIDs in the 6-OHDA rat model (Carta et al., 2007). The rationale for the use of these agonists consists in a possible modulation of DA release from 5-HT neurons in a way that resembles the physiological DA release from DA neurons. Hitherto, this attractive hypothesis has not been validated by a human study.

In addition, 5- $\mathrm{HT}_{2 \mathrm{C}}$ receptors might be involved in LID. The changes in $5-\mathrm{HT}_{2 \mathrm{C}}$ receptor binding reported by Fox et al. (1998) were seen in PD patients with LID. It is thus possible that they could be ascribed to the process underlying dyskinesia rather than parkinsonism (Fox et al., 1998). Thus, reduced stimulation of $5-\mathrm{HT}_{2 \mathrm{C}}$ 
receptors would lead to decreased activity of the basal ganglia output nuclei and increased levels of abnormal movements. This hypothesis may predict an efficacious use of $5-\mathrm{HT}_{2 \mathrm{C}}$ agonists for alleviating the side effects of long-term treatment with L-DOPA. This seems unlikely since clozapine and quetiapine, antagonists for this receptor subtype, have been used successfully for this purpose (Durif et al., 2004). On the other hand, systemic administration of the selective $5-\mathrm{HT}_{2 \mathrm{C}}$ antagonist SB 206553 was shown to enhance the anti-parkinsonian action of the DA $\mathrm{D}_{1}$ and $\mathrm{D}_{2}$ agonists in 6-OHDA-lesioned rats (Fox et al., 1998; Fox and Brotchie, 2000a), suggesting that the use of a $5-\mathrm{HT}_{2 \mathrm{C}}$ receptor antagonist in combination with a DA receptor agonist may reduce the reliance upon DA replacement therapies. Hitherto, no studies have been conducted in either non-human primates or humans to address this issue. For a more extended treatment of this subject, see Chapters 22 and 23.

\section{Role of 5-HT in parkinsonian resting tremor}

Furthermore, convincing evidence has indicated a pivotal role of 5-HT in parkinsonian resting tremor. The most common tremor seen in patients with PD is a 'pill-rolling' movement of the hands (Sethi, 2003). Despite a number of clinical and basic studies, the neural substrate for this motor complication remains unclear. The causative role of 5-HT in tremorgenesis has been strengthened by a recent PET study in PD patients (Doder et al., 2003). Interestingly, these authors showed that severity of parkinsonian tremor, but not rigidity or bradykinesia, was correlated significantly with this decrease in midbrain raphe $5-\mathrm{HT}_{1 \mathrm{~A}}$ binding, likely reflecting a dysfunction and loss of serotonergic cell bodies early in the disease process (Doder et al., 2003). This evidence is in agreement with the suggested hypothesis of 'disequilibria' in the 5-HT-histamine system responsible for tremor (akathisia), whereas 'disequilibria' in the DA-ACh system might lead to rigidity (akinesia) (Barbeau, 1962). A glimmer of light on the potential of subtype-selective serotonergic agents for the relief of parkinsonian tremor was recently thrown by Carlson and colleagues (Carlson et al., 2003).
Local injections of a mixed $5-\mathrm{HT}_{2 \mathrm{~A} / 2 \mathrm{C}}$ receptor antagonist into the $\mathrm{SNr}$ block tremulous jaw movements in a cholinomimetic model of parkinsonian tremor in rats (Carlson et al., 2003). This result is consistent with previous studies showing that the jaw movement activity was suppressed potently by clozapine, olanzapine and risperidone (Ikeguchi and Kuroda, 1995; Trevitt et al., 1997, 1998) and clinical reports demonstrating serotonergic involvement in the generation and treatment of parkinsonian symptoms and other motor disorders (Ikeguchi and Kuroda, 1995).

\section{Role of 5-HT in psychiatric complications in PD}

Besides being a movement disorder, PD is also associated with numerous non-motor symptoms. Mood disturbance, and especially major depressive disorder, has an average prevalence of $25-40 \%$ in outpatient settings (Leentjens, 2004; Veazey et al., 2005; Miller et al., 2007). According to the serotonergic hypothesis of depression in PD (Mayeux, 1990), 5-HT seems to play a central role. Indeed, it has been suggested that the reduced DA activity in PD can lead, as physiological adaptation, to a reduction of serotonergic tone and, at the same time, constitute a risk factor for depression (Mayeux, 1990). The presence of this biological risk factor for depression may explain the high prevalence of this condition in patients with PD (Leentjens, 2004). Nevertheless, a recent double-blind, randomized study provided no support for the serotonergic hypothesis of depression in PD, using the acute tryptophan depletion (ATD) paradigm (Leentjens et al., 2006). Comorbid depression in PD is usually treated with SSRIs or tricyclic antidepressants (TCAs), although these drugs should be used with caution in patients with PD because they can exacerbate orthostatic hypotension and anticholinergic adverse effects (Veazey et al., 2005).

We have recently suggested that $5-\mathrm{HT}_{2 \mathrm{C}}$ receptor antagonists prove useful in addressing depression and also, in PD patients, increasing the activity of ventral tegmental area (VTA) DA neurons and accumbal DA release (Di Giovanni et al., 2006a, b). In accord with this, nefazodone, a $5-\mathrm{HT}_{2}$ antagonist/reuptake inhibitor, has shown a 
dual activity: as an antidepressant and as an agent capable of reducing the EPS in depressed PD patients (Avila et al., 2003). Given these desirable motor side effects, nefazodone should be chosen over SSRIs for the treatment of depression in PD patients if they tolerate its use (Avila et al., 2003).

Apart from depression, dementia and psychosis are also common psychiatric problems associated with PD. Psychotic complications are associated with the use of anti-parkinsonian drugs and make PD management more difficult, given the need for anti-DAergic therapy, which worsens motor functioning in patients with PD. For psychosis, clozapine is the only atypical antipsychotic that has proven effective without worsening motor function in PD patients. However, its use requires the monitoring of agranulocytosis. Newer atypical APDs, such as quetiapine, have been claimed to be safe in terms of motor functioning, but evidence about their effectiveness is not compelling. The efficacy of the atypical APDs in treating psychosis in PD patients is likely to be due to their ability in blocking 5-HT receptors. In fact, antagonists or inverse agonists of the $5-\mathrm{HT}_{2 \mathrm{~A}}$ and $5-\mathrm{HT}_{2 \mathrm{C}}$ receptor are potential therapeutic agents for treatment-induced psychosis of PD (Weiner et al., 2003; Di Giovanni et al., 2006a).

\section{Role of 5-HT in APD-induced extrapyramidal side effects}

In addition to the neurodegenarative, idiopathic form, parkinsonian symptoms are also produced by therapies using typical APDs such as haloperidol, a mixed DA antagonist. In fact, EPS are common neurological side effects of APD medication. More than $60 \%$ of the people who take conventional antipsychotic medications experience some form of EPS. These side effects can occur within the first few days or weeks of treatment or appear after months and years of antipsychotic medication use. EPS are more common among patients taking conventional antipsychotic medications, compared to the newer atypical drugs. EPS can cause a variety of symptoms, e.g. involuntary movements, tremors and rigidity, body restlessness, muscle contractions and changes in breathing and heart rate. Drug-induced EPS are categorized into acute (acute dystonia, parkinsonism and akathisia) and delayed [tardive dyskinesia (TD)] syndromes, based on the time of occurrence during antipsychotic treatment. Neurolepticinduced parkinsonism is characterized by the triad of tremor, rigidity and bradykinesia; it can closely resemble idiopathic PD caused by nigrostriatal degeneration. TD is the major limitation of longterm APD therapy, being potentially irreversible. This condition occurs in $15-30 \%$ of patients and results in abnormal, unintentional choreoathetoid movements of the head, limbs and trunk. The incidence of akathisia, parkinsonian syndromes and TD, which are relatively frequent in patients treated with classical antipsychotic agents, is also similar to that in patients treated with TCAs and SSRIs. Amitriptiline, clomipramine, doxepine, trazodone and fluoxetine induce TD in patients not previously treated with neuroleptics (Mander et al., 1994; Clayton, 1995; Bharucha and Sethi, 1996), and akathisia, acute dystonia and pseudoparkinsonism have been induced by some of these drugs, although not all share the same risk for the development of movement disturbances.

It has been proposed that DA receptors' supersensitivity, arising from up-regulation of $\mathrm{DA}_{2}$ receptors following APDs, is the base for the development of TD. In addition to DA, 5-HT receptors are also important in the aetiology of schizophrenia and the elicitation of EPS. Particularly 5- $\mathrm{HT}_{1 \mathrm{~A}}, \quad 5-\mathrm{HT}_{2 \mathrm{~A} / 2 \mathrm{C}}$ and $5-\mathrm{HT}_{3}$ receptor signalling seems to be altered in TD. Recently, a possible genetic predisposition to develop TD exists, and association between TD and receptor gene polymorphisms of $5-\mathrm{HT}_{2 \mathrm{~A}}$ and $5-\mathrm{HT}_{2 \mathrm{C}}$ genes has actually been shown (Gunes et al., 2007, 2008).

$5-\mathrm{HT}_{1 \mathrm{~A}}$ receptors may be important since the postsynaptic $5-\mathrm{HT}_{1 \mathrm{~A}}$ receptor density in the prefrontal and temporal cortices of patients with schizophrenia is elevated (Tauscher et al., 2002). Probably, a resultant decrease in the normal inhibitory serotonergic influence on motor activity may be involved in the precipitation of TD in patients on haloperidol therapy, since chronic administration of haloperidol increased the responsiveness of presynaptic and postsynaptic $5-\mathrm{HT}_{1 \mathrm{~A}}$ receptors and reduced 5-HT turnover 
(Haleem and Khan, 2003). Consistently, repeated administration of low doses of buspirone, a partial agonist at $5-\mathrm{HT}_{1 \mathrm{~A}}$ receptors, decreased the responsiveness of $5-\mathrm{HT}_{1 \mathrm{~A}}$ receptors (Okazawa et al., 1999) and reversed haloperidol-induced deficits of exploratory activity (Haleem et al., 2007a, b). In a widely accepted rat model of TD obtained with chronic treatment by neuroleptics (Ellison and See, 1989) 8-OHDPAT (Naidu and Kulkarni, 2001a) and sarizotan, a $5-\mathrm{HT}_{1 \mathrm{~A}}$ agonist $/ \mathrm{D}_{3} / \mathrm{D}_{4}$ ligand (Rosengarten et al., 2006) treatment inhibited haloperidol-induced vacuous chewing movements (VCMs). Consistently, buspirone reversed reserpine-induced dyskinetic movements in rats (Queiroz and Frussa-Filho, 1999) and completely reversed the induction of tardive VCMs (Haleem et al., 2007a, b).

The evidence that buspirone, at low doses, preferentially acts at the somatodendritic $5-\mathrm{HT}_{1 \mathrm{~A}}$ receptors further supports the hypothesis of impaired somatodendritic 5-HT function (Haleem and Khan, 2003; Haleem et al., 2007a, b). These compelling experimental data support an impairment of 5-HT transmission as a possible important contributing factor in the onset of TD and other parkinsonian-like effects of neuroleptics. Repeated administration of haloperidol elicits an increase in the responsiveness of somatodendritic and postsynaptic $5-\mathrm{HT}_{1 \mathrm{~A}}$ receptors. An increase in the effectiveness of somatodendritic $5-\mathrm{HT}_{1 \mathrm{~A}}$ receptors in rats treated with haloperidol would be expected to decrease the 5-HT input to DA nuclei. Buspirone and 8-OHDPAT might act in reversal of haloperidol-induced dyskinesia by desensitization of $5-\mathrm{HT}_{1 \mathrm{~A}}$ receptors, suggesting that prior administration of buspirone may be of help in the improvement of EPS induced by haloperidol and other antipsychotic drugs (Haleem et al., 2004; Samad et al., 2007).

$5-\mathrm{HT}_{2 \mathrm{C}}$ receptor signalling is also deeply implicated in the development of VCMs and $5-\mathrm{HT}_{2 \mathrm{C}}$ receptors, which become supersensitized during long-term haloperidol treatment and remain supersensitized even after withdrawal of haloperidol as a treatment (Wolf et al., 2005; Ikram et al., 2007). In fact, mCPP enhances the oral activity response to a greater extent than the $\mathrm{DA} \mathrm{D}_{1}$ receptor agonist SKF 38393 in neonatal 6-OHDA-treated rats (Gong and Kostrzewa, 1992). It is likely that $\mathrm{mCPP}$ produces its effect at $5-\mathrm{HT}_{2}$ (probably $5-\mathrm{HT}_{2 \mathrm{C}}$ ) receptors being blocked by the largely $5-\mathrm{HT}_{2}$ receptor antagonist mianserin (Gong and Kostrzewa, 1992). Moreover, DA $D_{1}$-induced VCMs also appear to be mediated ultimately by $5-\mathrm{HT}_{2 \mathrm{C}}$ receptors and, as a result, are attenuated by mianserin (Gong and Kostrzewa, 1992). It is significant that various $5-\mathrm{HT}_{2}$ receptor antagonists, such as seganserin, ketanserin and ritanserin, are able to effectively reduce the number of spontaneous VCMs in a rat model of TD (Naidu and Kulkarni, 2001a).

Concordantly, clozapine and other atypical APDs that also have a high affinity for $5-\mathrm{HT}_{2 \mathrm{C}}$ receptors (Altar et al., 1986) reduced motor side effect liability because of the same degree of intrinsic anti-parkinsonian characteristics, which act to counteract the pro-parkinsonian effects of DA blockade. This was suggested by early clinical studies indicating that the $5-\mathrm{HT}_{2 \mathrm{~A} / 2 \mathrm{C}}$ receptor antagonist ritanserin (Leysen et al., 1985; Bersani et al., 1990) can ameliorate negative symptoms as well as attenuate exciting EPS in schizophrenics treated with classical APDs (Bersani et al., 1990; Miller et al., 1990). The relevance of $5-\mathrm{HT}_{2 \mathrm{C}}$ receptor blocking in the effect of atypical APDs was shown by Canton et al. (1990), who revealed the high affinity of clozapine and risperidone for $5-\mathrm{HT}_{2 \mathrm{C}}$ sites in the rat choroid plexus. These findings were subsequently confirmed (Kuoppamaki et al., 1993, 1995; Schotte et al., 1993; Canton et al., 1994) and extended to brain sections (Roth et al., 1992, 1998). Antagonism at 5-HT $2 \mathrm{C}$ receptors by several atypical antipsychotics was also observed in vivo. Indeed, clozapine produces an increase in extracellular levels of DA in the nucleus accumbens (Di Matteo et al., 2002; Shilliam and Dawson, 2005), reverses the inhibition of accumbal DA release induced by the 5-HT $2 \mathrm{C}$ agonist Ro 60-175 (Di Matteo et al., 2002) and blocks the hypolocomotion induced by the $5-\mathrm{HT}_{2 \mathrm{C}}$ agonist mCPP (Prinssen et al., 2000).

It is noteworthy that clozapine, like several atypical APDs, behaves as a $5 \mathrm{HT}_{2 \mathrm{C}}$ inverse agonist in heterologous expression systems in vitro (Herrick-Davis et al., 2000; Rauser et al., 2001; 
Navailles et al., 2006) and in vivo (Navailles et al., 2006). Thus, the $5-\mathrm{HT}_{2 \mathrm{C}}$ receptor inverse agonist might underlie the unique clinical properties of atypical APDs, such as low EPS profile and good anti-dyskinetic efficacy (Herrick-Davis et al., 2000; Durif et al., 2004; Navailles et al., 2006).

Despite different chemical structures and pharmacodynamic signalling pathways, a number of antipsychotics inhibit ion fluxes through $5-\mathrm{HT}_{3}$ receptors in a noncompetitive manner, with the exception of the known competitive antagonists mirtazapine, olanzapine and clozapine (Bymaster et al., 2001; Rammes et al., 2004; Eisensamer et al., 2005). In accord with these findings, it has been shown that $5-\mathrm{HT}_{3}$ receptor antagonists ondansetron and tropisetron dose dependently reversed the haloperidol-induced VCMs and reduced haloperidol-induced wet dog shakes, further supporting the possibility of an alteration in the serotonergic system after chronic haloperidol treatment (Naidu and Kulkarni, 2001b). It can be concluded that these 5-HT receptors can serve as potential therapeutic targets for the development of novel molecules for the treatment and prevention of TD.

\section{Catalepsy}

The neuroleptic-induced state of catalepsy is generally considered as an animal model of the akinesia and rigidity seen in PD, which is predictive of EPS for APDs. 5-HT is also implicated in APD-induced catalepsy (Wadenberg, 1996). For example, different SSRIs attenuate haloperidol-induced catalepsy in mice (Pires et al., 2005). In addition, the $5-\mathrm{HT}_{1 \mathrm{~A}}$ receptor agonists 8 -OHDPAT and buspirone, and the $5-\mathrm{HT}_{2 \mathrm{~A} / 2 \mathrm{C}}$ receptor agonists DOI and 1-(2,5-dimethoxy-4bromophenyl)-2-aminopropane (DOB), attenuate $\mathrm{D}_{2}$ receptor-mediated catalepsy (Invernizzi et al., 1988; Hicks, 1990; Neal-Beliveau et al., 1993; Lucas et al., 1997). Moreover, the anti-cataleptic effects of 8-OHDPAT and DOI are antagonized by WAY 100635 , a selective $5-\mathrm{HT}_{1 \mathrm{~A}}$ receptor antagonist (Bartoszyk et al., 1996), and mianserin, a $5-\mathrm{HT}_{2 \mathrm{~A} / 2 \mathrm{C}}$ receptor antagonist (Neal-Beliveau et al., 1993), respectively. In addition, 5-HT $1 \mathrm{~A}$ receptor activation reduces the cataleptogenic potential of novel antipsychotic agents such as ziprasidone, aripiprazole, bifeprunox, SLV313, SSR181507 and sarizotan (Kleven et al., 2005). These findings strongly indicate that the serotonergic system is involved in the onset of catalepsy. There is strong evidence to suggest that (1) the catalepsy produced by $\mathrm{DA} \mathrm{D}_{1}$ or $\mathrm{D}_{2}$ receptor antagonists can be completely antagonized by the administration of $5-\mathrm{HT}_{1 \mathrm{~A}}$ receptor agonists acting at $5-\mathrm{HT}_{1 \mathrm{~A}}$ autoreceptors in the DRN and (2) the catalepsy produced by a $\mathrm{DA} \mathrm{D}_{2}$ receptor antagonist can be completely antagonized by treatment with a $5-\mathrm{HT}_{2 \mathrm{~A} / 2 \mathrm{C}}$ receptor agonist.

On the other hand, it has been shown that clozapine inhibits the cataleptic response to loxapine and olanzapine but does not induce catalepsy by itself (Kalkman et al., 1997). In addition, behavioural evidence shows that SB 228357, a selective 5- $\mathrm{HT}_{2 \mathrm{~B} / 2 \mathrm{C}}$ receptor antagonist, and ACP-103, a 5- $\mathrm{HT}_{2 \mathrm{~A}}$ receptor inverse agonist, attenuated catalepsy produced by haloperidol or risperidone (Reavill et al., 1999; Gardell et al., 2007). On the other hand, the $5-\mathrm{HT}_{2 \mathrm{~A}}$ and $5-\mathrm{HT}_{2 \mathrm{~B}}$ receptor antagonists MDL 100907 and SB 215505 did not reverse haloperidol-induced catalepsy. These data suggest a role for $5-\mathrm{HT}_{2 \mathrm{C}}$ receptors in the anti-cataleptic action of SB 228357. Thus, the blockade of $5-\mathrm{HT}_{2 \mathrm{C}}$ receptors, instead of their activation, would play a role in relieving the neuroleptic EPS disturbance. This hypothesis is further reinforced by the observation that the $5-\mathrm{HT}_{2 \mathrm{C}}$ receptor activation by Ro 600175 per se induces catalepsy (Grottick et al., 2000).

Therefore, another interesting application of the data regarding the functional role of 5-HT in the basal ganglia is the possible use of 5-HT receptor ligands in the treatment of drug-induced parkinsonian syndromes in relation to present efforts to develop new atypical neuroleptics with affinity for brain 5-HT receptor subtypes.

Hitherto, only one piece of research has investigated the effect of $5-\mathrm{HT}_{6}$ receptor antagonism on catalepsy and in rats with unilateral 6-OHDA lesions (Bourson et al., 1998). Ro 04-6790, a 5- $\mathrm{HT}_{6}$ selective antagonist, did not induce catalepsy nor did it have any effect on either haloperidol- or SCH 23390-induced catalepsy. Administration of Ro 04-6790 was instead 
able to reverse rotational behaviour induced by the muscarinic antagonists scopolamine and atropine in unilaterally 6-OHDA-lesioned rats. These data suggest that the $5-\mathrm{HT}_{6}$ receptor is involved in the control of cholinergic neurotransmission in the striatum that is distal to DA transmission. A possible mechanism could be an increase in ACh release induced by $5-\mathrm{HT}_{6}$ receptor blockades directly or through modulation of GABA neurotransmission in the striatum, since $5-\mathrm{HT}_{6}$ receptors are expressed on GABA spiny neurons. In addition, Ro 04-6790 alone did not induce turning behaviour in the unilaterally lesioned rat nor did it potentiate or inhibit ipsilateral rotations induced by amphetamine. Furthermore, Ro 04-6790 had no effect on the contralateral rotations induced by L-DOPA. Therefore, $5-\mathrm{HT}_{6}$ receptor affinity does not account for the lack of EPS - effects characteristic of clozapine-like compounds (Bourson et al., 1998).

\section{Conclusions}

From the large amount of literature reviewed here, it appears evident that the serotonergic neurotransmitter system plays a pivotal role in the modulation of basal ganglia circuitry (Fig. 1), and its dysfunction is involved in the pathophysiology of PD and other motor disorders.

Among all the 5-HT receptors present in the basal ganglia nuclei, the $5-\mathrm{HT}_{1 \mathrm{~A} / 1 \mathrm{~B}}$ and $5-\mathrm{HT}_{2 \mathrm{~A} / 2 \mathrm{C}}$ receptors are particularly important, because of their localization and regulatory role on neurotransmitter release in many basal ganglia circuitry, including GLUergic terminals in the SNc (Pineyro and Blier, 1999). 5-HT $1 \mathrm{~A}$ receptor agonists have the potential for being useful at different stages of PD progression since they may provide symptomatic relief in early $\mathrm{PD}$, and anti-dyskinetic efficacy in a later stage. Moreover, it has been shown (Bezard et al., 2006) that 5- $\mathrm{HT}_{1 \mathrm{~A}}$ receptor agonists could also present (partial) neuroprotection, partially blocking the excitotoxic cycle of circuit-driven degeneration caused by the overactivity of the STN afferents of DA neurons, decreasing the hyperactivity of the remaining DA neurons through opening of potassium conductances and suppressing activity of the vulnerability factor caspase-3 in the remaining DA neurons.

Although several selective agents for 5-HT receptors have been discovered, none has reached the market for the treatment of motor disorders as yet. However, several companies are very active in 5-HT receptor research in $\mathrm{PD}$, although they have concentrated on different receptor subtypes. Nevertheless despite the promising findings, last year, Merck KGaA decided to stop further development of its late-stage development drug sarizotan as a treatment for PD. The company took the decision after examining the results of two Phase III studies of sarizotan in advanced PD patients with dyskinesia. A statement from Merck KGaA said that the Phase III studies did not confirm earlier Phase II findings or the results from preclinical studies. The two trials, PADDY 1 and PADDY 2, investigated twice-daily dosing of sarizotan 1-mg tablets, to investigate whether the drug could achieve a $25 \%$ improvement in dyskinesia symptoms, but it failed to meet this efficacy threshold.

From the data reviewed here, it should be clear that drugs acting at the $5-\mathrm{HT}_{2 \mathrm{~A} / 2 \mathrm{C}}$ receptors might be an important feature of the treatment of $\mathrm{PD}$, drug-related motor disturbances and the psychiatric symptoms often associated with these neurological disorders. Nevertheless, as happened for the $5-\mathrm{HT}_{1 \mathrm{~A}}$ receptors, no compounds selective for $5-\mathrm{HT}_{2 \mathrm{~A} / 2 \mathrm{C}}$ receptors have been released for the treatment of major motor disturbances such as PD. A glimmer of hope comes from the pharmaceutical company Acadia, which, in 2007, initiated the first Phase III pivotal trial with pimavanserin, a $5-\mathrm{HT}_{2 \mathrm{~A}}$ inverse agonist in $\mathrm{PD}$ patients with PD psychosis, after having positively concluded Phase II.

NS-2330, a triple monoamine reuptake inhibitor, has shown therapeutic potential in PD. In 2006, NeuroSearch's global partner Boehringer Ingelheim has concluded that the results from three completed Phase II clinical studies in PD did not meet the company's efficacy criteria to proceed with Phase III clinical development.

5-HT research is now more than 50 years old and has generated a wealth of therapeutic agents, 
some of which have had a major impact on disease management. SSRIs are among the most widely prescribed drugs for treating depression and a variety of other disorders, including anxiety and social phobia. But we are a long way from a serotonergic therapeutic intervention for PD.

5-HT receptor research has generated detailed information on the molecular biology and regional and cellular localization of these receptors. A major challenge now is to utilize this knowledge to develop receptor-specific drugs and use the information gained to better treat CNS disorders. In addition, further clarification of the role of 5-HT transmission in the pathophysiology of basal ganglia disorders is required since the overall picture is still confusing. Furthermore, most of the data came from animal studies and animal models of PD that yielded contrary results compared to clinical studies. This leaves room for speculation about the real value of preclinical research for clinical PD. Moreover, there are also many avenues that remain unexplored, so there are undoubtedly further advances to be made.

$\begin{array}{ll}\text { GPi } & \text { internal segment of the GP } \\ \text { HFS } & \text { high-frequency stimulation } \\ \text { IPSCs } & \text { inhibitory postsynaptic currents } \\ \text { LAIs } & \text { large aspiny interneurons } \\ \text { L-DOPA } & \text { levodopa } \\ \text { LID } & \text { L-DOPA-induced dyskinesia } \\ \text { MPTP } & \text { 1-methyl 4-phenyl 1,2,3,6-tetrahy- } \\ & \text { dropyridine } \\ \text { MRN } & \text { medial raphe nucleus } \\ \text { MSNs } & \text { medium spiny neurons } \\ \text { NMR } & \text { nucleus raphe magnus } \\ \text { NRO } & \text { nucleus raphe obscurus } \\ \text { NRP } & \text { nucleus raphe pallidus } \\ \text { PLC } & \text { phospholipase C } \\ \text { PPN } & \text { pedunculopontino nucleus } \\ \text { SN } & \text { substantia nigra } \\ \text { SNc } & \text { SN pars compacta } \\ \text { SNr } & \text { SN pars reticulata } \\ \text { SSRIs } & \text { selective serotonin reuptake inhibi- } \\ & \text { tors } \\ \text { STN } & \text { subthalamic nucleus } \\ \text { TCAs } & \text { tricyclic antidepressants } \\ \text { TD } & \text { tardive dyskinesia } \\ \text { TPH } & \text { tryptophan hydroxylase } \\ \text { VCMs } & \text { vacuous chewing movements } \\ \text { VTA } & \text { ventral tegmental area }\end{array}$

$\begin{array}{ll}\text { Abbreviations } & \\ \text { 5-HIIA } & \text { 5-hydroxy-indolacetic acid } \\ \text { 5-HT } & \text { serotonin } \\ \text { 5-HTT } & \text { 5-HT transporter } \\ \text { 6-OHDA } & \text { 6-hydroxydopamine } \\ \text { ACh } & \text { acetylcholine } \\ \text { AHPs } & \text { after-hyperpolarizations } \\ \text { APDs } & \text { antipsychotic drugs } \\ \text { ATD } & \text { acute tryptophan depletion } \\ \text { CNS } & \text { central nervous system } \\ \text { DA } & \text { dopamine } \\ \text { DBS } & \text { deep brain stimulation } \\ \text { DRN } & \text { dorsal raphe nucleus } \\ \text { EPN } & \text { entopeduncular nucleus } \\ \text { EPS } & \text { extrapyramidal symptoms } \\ \text { EPSCs } & \text { excitatory postsynaptic currents } \\ \text { GLU } & \text { glutamate } \\ \text { GP } & \text { globus pallidus } \\ \text { GPe } & \text { external segment of the GP }\end{array}$

\section{References}

Abi-Dargham, A., Laruelle, M., Wong, D.T., Robertson, D.W., Weinberger, D.R. and Kleinman, J.E. (1993) Pharmacological and regional characterization of [3H]LY278584 binding sites in human brain. J. Neurochem., 60(2): 730-737.

Albin, R.L., Young, A.B. and Penney, J.B. (1989) The functional anatomy of basal ganglia disorders. Trends Neurosci., 12(10): 366-375.

Altar, C.A., Wasley, A.M., Neale, R.F. and Stone, G.A. (1986) Typical and atypical antipsychotic occupancy of D2 and S2 receptors: an autoradiographic analysis in rat brain. Brain Res. Bull., 16(4): 517-525.

Antonelli, T., Fuxe, K., Tomasini, M.C., Bartoszyk, G.D., Seyfried, C.A., Tanganelli, S. and Ferraro, L. (2005) Effects of sarizotan on the corticostriatal glutamate pathways. Synapse, 58(3): 193-199.

Avila, A., Cardona, X., Martin-Baranera, M., Maho, P., Sastre, F. and Bello, J. (2003) Does nefazodone improve both depression and Parkinson disease? A pilot randomized trial. J. Clin. Psychopharmacol., 23(5): 509-513.

Azmitia, E.C. and Segal, M. (1978) An autoradiographic analysis of the differential ascending projections of the dorsal 
and median raphe nuclei in the rat. J. Comp. Neurol., 179(3): 641-667.

Balcioglu, A., Zhang, K. and Tarazi, F.I. (2003) Dopamine depletion abolishes apomorphine- and amphetamine-induced increases in extracellular serotonin levels in the striatum of conscious rats: a microdialysis study. Neuroscience, 119(4): 1045-1053.

Barbeau, A. (1962) The pathogenesis of Parkinson's disease: a new hypothesis. Can. Med. Assoc. J., 87: 802-807.

Barnes, J.M., Barnes, N.M., Champaneria, S., Costall, B. and Naylor, R.J. (1990) Characterisation and autoradiographic localisation of 5-HT3 receptor recognition sites identified with $[3 \mathrm{H}]-(\mathrm{S})$-zacopride in the forebrain of the rat. Neuropharmacology, 29(11): 1037-1045.

Barnes, N.M. and Sharp, T. (1999) A review of central 5-HT receptors and their function. Neuropharmacology, 38(8): 1083-1152.

Bartoszyk, G.D., Roos, C. and Ziegler, H. (1996) 5-HT1A receptors are not involved in clozapine's lack of cataleptogenic potential. Neuropharmacology, 35(11): 1645-1646.

Barwick, V.S., Jones, D.H., Richter, J.T., Hicks, P.B. and Young, K.A. (2000) Subthalamic nucleus microinjections of 5-HT2 receptor antagonists suppress stereotypy in rats. Neuroreport, 11(2): 267-270.

Basura, G.J. and Walker, P.D. (1999) Serotonin 2A receptor mRNA levels in the neonatal dopamine-depleted rat striatum remain upregulated following suppression of serotonin hyperinnervation. Brain Res. Dev. Brain Res., 116(1): 111-117.

Basura, G.J. and Walker, P.D. (2001) Serotonin 2A receptor regulation of striatal neuropeptide gene expression is selective for tachykinin, but not enkephalin neurons following dopamine depletion. Brain Res. Mol. Brain Res., 92(1-2): 66-77.

Bata-Garcia, J.L., Heredia-Lopez, F.J., Alvarez-Cervera, F.J., Arankowsky-Sandoval, G. and Gongora-Alfaro, J.L. (2002) Circling behavior induced by microinjection of serotonin reuptake inhibitors in the substantia nigra. Pharmacol. Biochem. Behav., 71(1-2): 353-363.

Belforte, J.E. and Pazo, J.H. (2004) Turning behaviour induced by stimulation of the 5-HT receptors in the subthalamic nucleus. Eur. J. Neurosci., 19(2): 346-355.

Bengtson, C.P., Lee, D.J. and Osborne, P.B. (2004) Opposing electrophysiological actions of 5-HT on noncholinergic and cholinergic neurons in the rat ventral pallidum in vitro. J. Neurophysiol., 92(1): 433-443.

Bersani, G., Grispini, A., Marini, S., Pasini, A., Valducci, M. and Ciani, N. (1990) 5-HT2 antagonist ritanserin in neuroleptic-induced parkinsonism: a double-blind comparison with orphenadrine and placebo. Clin. Neuropharmacol., 13(6): 500-506.

Bezard, E., Brotchie, J.M. and Gross, C.E. (2001) Pathophysiology of levodopa-induced dyskinesia: potential for new therapies. Nat. Rev. Neurosci., 2(8): 577-588.

Bezard, E., Gerlach, I., Moratalla, R., Gross, C.E. and Jork, R. (2006) 5-HT1A receptor agonist-mediated protection from MPTP toxicity in mouse and macaque models of Parkinson's disease. Neurobiol. Dis., 23(1): 77-86.
Bezard, E., Gross, C.E. and Brotchie, J.M. (2003) Presymptomatic compensation in Parkinson's disease is not dopaminemediated. Trends Neurosci., 26(4): 215-221.

Bharucha, K.J. and Sethi, K.D. (1996) Complex movement disorders induced by fluoxetine. Mov. Disord., 11(3): 324-326.

Bhidayasiri, R. and Truong, D.D. (2004) Chorea and related disorders. Postgrad. Med. J., 80(947): 527-534.

Birkmayer, W. and Birkmayer, J.D. (1987) Dopamine action and disorders of neurotransmitter balance. Gerontology, 33(3-4): 168-171.

Birkmayer, W. and Riederer, P. (1986) Biological aspects of depression in Parkinson's disease. Psychopathology, 19(2): 58-61.

Bishop, C., Daut, G.S. and Walker, P.D. (2005) Serotonin 5-HT2A but not 5-HT2C receptor antagonism reduces hyperlocomotor activity induced in dopamine-depleted rats by striatal administration of the D1 agonist SKF 82958. Neuropharmacology, 49(3): 350-358.

Bishop, C., Tessmer, J.L., Ullrich, T., Rice, K.C. and Walker, P.D. (2004) Serotonin 5-HT2A receptors underlie increased motor behaviors induced in dopamine-depleted rats by intrastriatal 5-HT2A/2C agonism. J. Pharmacol. Exp. Ther., 310(2): 687-694.

Blackburn, T.P. (2004) Serotonergic agents and Parkinson's disease. Drug Discov. Today Ther. Strateg., 1: 35-41.

Blackburn, T.P., Cox, B., Heapy, C.G., Lee, T.F. and Middlemiss, D.N. (1981) Supersensitivity of nigral serotonin receptors and rat rotational behaviour. Eur. J. Pharmacol., 71(2-3): 343-346.

Blackburn, T.P., Kemp, J.D., Martin, D.A. and Cox, B. (1984) Evidence that 5-HT agonist-induced rotational behaviour in the rat is mediated via 5-HT1 receptors. Psychopharmacology (Berl.), 83(2): 163-165.

Blomeley, C. and Bracci, E. (2005) Excitatory effects of serotonin on rat striatal cholinergic interneurones. J. Physiol. (Lond.), 569(Pt 3): 715-721.

Blurton, P.A. and Wood, M.D. (1986) Identification of multiple binding sites for $[3 \mathrm{H}] 5$-hydroxytryptamine in the rat CNS. J. Neurochem., 46(5): 1392-1398.

Boess, F.G. and Martin, I.L. (1994) Molecular biology of 5-HT receptors. Neuropharmacology, 33(3-4): 275-317.

Bonaventure, P., Hall, H., Gommeren, W., Cras, P., Langlois, X., Jurzak, M. and Leysen, J.E. (2000) Mapping of serotonin 5-HT(4) receptor mRNA and ligand binding sites in the postmortem human brain. Synapse, 36(1): 35-46.

Bonaventure, P., Voorn, P., Luyten, W.H., Jurzak, M., Schotte, A. and Leysen, J.E. (1998) Detailed mapping of serotonin 5-HT1B and 5-HT1D receptor messenger RNA and ligand binding sites in guinea-pig brain and trigeminal ganglion: clues for function. Neuroscience, 82(2): 469-484.

Bonsi, P., Cuomo, D., Ding, J., Sciamanna, G., Ulrich, S., Tscherter, A., Bernardi, G., Surmeier, D.J. and Pisani, A. (2007a) Endogenous serotonin excites striatal cholinergic interneurons via the activation of 5-HT 2C, 5-HT6, and 5-HT7 serotonin receptors: implications for extrapyramidal 
side effects of serotonin reuptake inhibitors. Neuropsychopharmacology, 32(8): 1840-1854.

Bonsi, P., Cuomo, D., Picconi, B., Sciamanna, G., Tscherter, A., Tolu, M., Bernardi, G., Calabresi, P. and Pisani, A. (2007b) Striatal metabotropic glutamate receptors as a target for pharmacotherapy in Parkinson's disease. Amino Acids, 32(2): 189-195.

Boschert, U., Amara, D.A., Segu, L. and Hen, R. (1994) The mouse 5-hydroxytryptamine1B receptor is localized predominantly on axon terminals. Neuroscience, 58(1): 167-182.

Bourson, A., Boess, F.G., Bös, M. and Sleight, A.J. (1998) Involvement of 5-HT6 receptors in nigro-striatal function in rodents. Br. J. Pharmacol., 125(7): 1562-1566.

Breese, G.R., Baumeister, A., Napier, T.C., Frye, G.D. and Mueller, R.A. (1985) Evidence that D-1 dopamine receptors contribute to the supersensitive behavioral responses induced by L-dihydroxyphenylalanine in rats treated neonatally with 6-hydroxydopamine. J. Pharmacol. Exp. Ther., 235(2): 287-295.

Breese, G.R., Knapp, D.J., Criswell, H.E., Moy, S.S., Papadeas, S.T. and Blake, B.L. (2005) The neonate-6hydroxydopamine-lesioned rat: a model for clinical neuroscience and neurobiological principles. Brain Res. Brain Res. Rev., 48(1): 57-73.

Brodie, B.B., Pletscher, A. and Shore, P.A. (1955) Evidence that serotonin has a role in brain function. Science, 122(3177): p. 968.

Brown, P. and Gerfen, C.R. (2006) Plasticity within striatal direct pathway neurons after neonatal dopamine depletion is mediated through a novel functional coupling of serotonin 5-HT2 receptors to the ERK $1 / 2$ map kinase pathway. J. Comp. Neurol., 498(3): 415-430.

Bruggeman, R., Heeringa, M., Westerink, B.H. and Timmerman, W. (2000) Combined 5-HT2/D2 receptor blockade inhibits the firing rate of SNR neurons in the rat brain. Prog. Neuropsychopharmacol. Biol. Psychiatry, 24(4): 579-593.

Bruinvels, A.T., Landwehrmeyer, B., Gustafson, E.L., Durkin, M.M., Mengod, G., Branchek, T.A., Hoyer, D. and Palacios, J.M. (1994) Localization of 5-HT1B, 5-HT1D alpha, 5-HT1E and 5-HT1F receptor messenger RNA in rodent and primate brain. Neuropharmacology, 33(3-4): 367-386.

Bruinvels, A.T., Palacios, J.M. and Hoyer, D. (1993a) Autoradiographic characterisation and localisation of 5-HT1D compared to 5-HT1B binding sites in rat brain. Naunyn Schmiedebergs Arch. Pharmacol., 347(6): 569-582.

Bruinvels, A.T., Palacios, J.M. and Hoyer, D. (1993b) 5-hydroxytryptaminel recognition sites in rat brain: heterogeneity of non-5-hydroxytryptamine1A/1C binding sites revealed by quantitative receptor autoradiography. Neuroscience, 53(2): 465-473.

Bubser, M., Backstrom, J.R., Sanders-Bush, E., Roth, B.L. and Deutch, A.Y. (2001) Distribution of serotonin 5-HT(2A) receptors in afferents of the rat striatum. Synapse, 39(4): 297-304.
Bufton, K.E., Steward, L.J., Barber, P.C. and Barnes, N.M (1993) Distribution and characterization of the [3H]granisetron-labelled 5-HT3 receptor in the human forebrain. Neuropharmacology, 32(12): 1325-1331.

Bymaster, F.P., Falcone, J.F., Bauzon, D., Kennedy, J.S., Schenck, K., DeLapp, N.W. and Cohen, M.L. (2001) Potent antagonism of 5-HT(3) and 5-HT(6) receptors by olanzapine. Eur. J. Pharmacol., 430(2-3): 341-349.

Canton, H., Verriele, L. and Colpaert, F.C. (1990) Binding of typical and atypical antipsychotics to 5-HT1C and 5-HT2 sites: clozapine potently interacts with 5-HT1C sites. Eur. J. Pharmacol., 191(1): 93-96.

Canton, H., Verriele, L. and Millan, M.J. (1994) Competitive antagonism of serotonin (5-HT)2C and 5-HT2A receptormediated phosphoinositide (PI) turnover by clozapine in the rat: a comparison to other antipsychotics. Neurosci. Lett., 181(1-2): 65-68.

Carlson, B.B., Wisniecki, A. and Salamone, J.D. (2003) Local injections of the 5-hydroxytryptamine antagonist mianserin into substantia nigra pars reticulata block tremulous jaw movements in rats: studies with a putative model of parkinsonian tremor. Psychopharmacology (Berl.), 165(3): 229-237.

Carlsson, T., Carta, M., Winkler, C., Bjorklund, A. and Kirik, D. (2007) Serotonin neuron transplants exacerbate L-DOPAinduced dyskinesias in a rat model of Parkinson's disease. J. Neurosci., 27(30): 8011-8022.

Carta, M., Carlsson, T., Kirik, D. and Bjorklund, A. (2007) Dopamine released from 5-HT terminals is the cause of L-DOPA-induced dyskinesia in parkinsonian rats. Brain, 130(Pt 7): 1819-1833.

Castro, M.E., Pascual, J., Romon, T., Berciano, J., Figols, J. and Pazos, A. (1998) 5-HT1B receptor binding in degenerative movement disorders. Brain Res., 790(1-2): 323-328.

Chadha, A., Sur, C., Atack, J. and Duty, S. (2000) The 5HT(1B) receptor agonist, CP-93129, inhibits [(3)H]-GABA release from rat globus pallidus slices and reverses akinesia following intrapallidal injection in the reserpine-treated rat. Br. J. Pharmacol., 130(8): 1927-1932.

Charles, P.D., Padaliya, B.B., Newman, W.J., Gill, C.E., Covington, C.D., Fang, J.Y., So, S.A., Tramontana, M.G., Konrad, P.E. and Davis, T.L. (2004) Deep brain stimulation of the subthalamic nucleus reduces antiparkinsonian medication costs. Parkinsonism Relat. Disord., 10(8): 475-479.

Chase, T.N. (1974) Serotonergic-dopaminergic interactions and extrapyramidal function. Adv. Biochem. Psychopharmacol., 11(0): 377-385.

Chase, T.N. and Ng, L.K. (1972) Central monoamine metabolism in Parkinson's disease. Arch. Neurol., 27(6): 486-491.

Chen, L., Yung, K.K., Chan, Y.S. and Yung, W.H. (2008) 5-HT excites globus pallidus neurons by multiple receptor mechanisms. Neuroscience, 151(2): 439-451.

Chinaglia, G., Landwehrmeyer, B., Probst, A. and Palacios, J.M. (1993) Serotoninergic terminal transporters are differentially affected in Parkinson's disease and progressive 
supranuclear palsy: an autoradiographic study with $[3 \mathrm{H}]$ citalopram. Neuroscience, 54(3): 691-699.

Chu, Y.X., Liu, J., Feng, J., Wang, Y., Zhang, Q.J. and Li, Q. (2004) [Changes of discharge rate and pattern of 5-hydroxytrypamine neurons of dorsal raphe nucleus in a rat model of Parkinson's disease]. Sheng Li Xue Bao, 56(5): 597-602.

Cicin-Sain, L. and Jenner, P. (1993) Reduction in cortical 5-HT3 binding sites following a unilateral 6-hydroxydopamine lesion of the medial forebrain bundle in rats. J. Neurol. Sci., 115(1): 105-110.

Clayton, A.H. (1995) Antidepressant-induced tardive dyskinesia: review and case report. Psychopharmacol. Bull., 31(2): 259-264.

Collingridge, G.L. and Davies, J. (1981) The influence of striatal stimulation and putative neurotransmitters on identified neurones in the rat substantia nigra. Brain Res., 212(2): 345-359.

Commins, D.L., Shaughnessy, R.A., Axt, K.J., Vosmer, G. and Seiden, L.S. (1989) Variability among brain regions in the specificity of 6-hydroxydopamine (6-OHDA)-induced lesions. J. Neural Transm., 77(2-3): 197-210.

Compan, V., Daszuta, A., Salin, P., Sebben, M., Bockaert, J. and Dumuis, A. (1996) Lesion study of the distribution of serotonin 5-HT4 receptors in rat basal ganglia and hippocampus. Eur. J. Neurosci., 8(12): 2591-2598.

Compan, V., Segu, L., Buhot, M.C. and Daszuta, A. (1998) Selective increases in serotonin $5-\mathrm{HT} 1 \mathrm{~B} / 1 \mathrm{D}$ and $5-\mathrm{HT} 2 \mathrm{~A} / 2 \mathrm{C}$ binding sites in adult rat basal ganglia following lesions of serotonergic neurons. Brain Res., 793(1-2): 103-111.

Cornea-Hébert, V., Riad, M., Wu, C., Singh, S.K. and Descarries, L. (1999) Cellular and subcellular distribution of the serotonin 5-HT2A receptor in the central nervous system of adult rat. J. Comp. Neurol., 409(2): 187-209.

Corvaja, N., Doucet, G. and Bolam, J.P. (1993) Ultrastructure and synaptic targets of the raphe-nigral projection in the rat. Neuroscience, 55(2): 417-427.

D’Addario, C., Di Benedetto, M., Izenwasser, S., Candeletti, S. and Romualdi, P. (2007) Role of serotonin in the regulation of the dynorphinergic system by a kappa-opioid agonist and cocaine treatment in rat CNS. Neuroscience, 144(1): 157-164.

Dahlström, A. and Fuxe, K. (1964) Evidence for the existence of monoamine-containing neurons in the central nervous system. I. Demonstration of monoamines in the cell bodies of brain stem neurons. Acta Physiol. Scand., 62(232): 1-55.

Darmani, N.A., Shaddy, J. and Gerdes, C.F. (1996) Differential ontogenesis of three DOI-induced behaviors in mice. Physiol. Behav., 60(6): 1495-1500.

Davies, J. and Tongroach, P. (1978) Neuropharmacological studies on the nigro-striatal and raphe-striatal system in the rat. Eur. J. Pharmacol., 51(2): 91-100.

De Deurwaerdere, P. and Chesselet, M.F. (2000) Nigrostriatal lesions alter oral dyskinesia and c-Fos expression induced by the serotonin agonist 1-(m-chlorophenyl)piperazine in adult rats. J. Neurosci., 20(13): 5170-5178.

del Arco, C., Galende, I. and Pazos, A. (1993) Autoradiographic mapping of 5-HT1 receptors in the guinea-pig brain with particular reference to the 5-HT1D receptor sites. Naunyn Schmiedebergs Arch. Pharmacol., 347(3): 248-256.

DeLong, M.R. (1990) Primate models of movement disorders of basal ganglia origin. Trends Neurosci., 13(7): 281-285.

Deniau, J.M. and Chevalier, G. (1985) Disinhibition as a basic process in the expression of striatal functions. II. The striatonigral influence on thalamocortical cells of the ventromedial thalamic nucleus. Brain Res., 334(2): 227-233.

Di Giovanni, G. (2008) Will it ever become possible to prevent dopaminergic neuronal degeneration? CNS Neurol. Disord. Drug Targets, 7(1): 28-44.

Di Giovanni, G., Di Matteo, V., La Grutta, V. and Esposito, E. (2001) $\mathrm{m}$-Chlorophenylpiperazine excites non-dopaminergic neurons in the rat substantia nigra and ventral tegmental area by activating serotonin-2C receptors. Neuroscience, 103(1): 111-116.

Di Giovanni, G., Di Matteo, V., Pierucci, M., Benigno, A. and Esposito, E. (2006a) Central serotonin2C receptor: from physiology to pathology. Curr. Top. Med. Chem., 6(18): 1909-1925.

Di Giovanni, G., Di Matteo, V., Pierucci, M., Benigno, A. and Esposito, E. (2006b) Serotonin involvement in the basal ganglia pathophysiology: could the 5-HT2C receptor be a new target for therapeutic strategies? Curr. Med. Chem., 13(25): 3069-3081.

Dijk, S.N., Francis, P.T., Stratmann, G.C. and Bowen, D.M. (1995) NMDA-induced glutamate and aspartate release from rat cortical pyramidal neurones: evidence for modulation by a 5-HT1A antagonist. Br. J. Pharmacol., 115(7): 1169-1174.

Di Matteo, V., Cacchio, M., Di Giulio, C., Di Giovanni, G. and Esposito, E. (2002) Biochemical evidence that the atypical antipsychotic drugs clozapine and risperidone block 5-HT(2C) receptors in vivo. Pharmacol. Biochem. Behav., 71(4): 607-613.

Doder, M., Rabiner, E.A., Turjanski, N., Lees, A.J. and Brooks, D.J. (2003) Tremor in Parkinson's disease and serotonergic dysfunction: an 11C-WAY 100635 PET study. Neurology, 60(4): 601-605.

Doucet, E., Miquel, M.C., Nosjean, A., Verge, D., Hamon, M. and Emerit, M.B. (1999) Immunolabeling of the rat central nervous system with antibodies partially selective of the short form of the 5-HT3 receptor. Neuroscience, 95(3): 881-892.

Dray, A., Gonye, T.J. and Oakley, N.R. (1976) Effects of alpha-flupenthixol on dopamine and 5-hydroxytryptamine responses of substantia nigra neurones. Neuropharmacology, 15(12): 793-796.

Duncan, G.E., Knapp, D.J., Breese, G.R., Crews, F.T. and Little, K.Y. (1998) Species differences in regional patterns of $3 \mathrm{H}-8-\mathrm{OH}-\mathrm{DPAT}$ and $3 \mathrm{H}$-zolpidem binding in the rat and human brain. Pharmacol. Biochem. Behav., 60(2): 439-448.

Durif, F., Debilly, B., Galitzky, M., Morand, D., Viallet, F., Borg, M., Thobois, S., Broussolle, E. and Rascol, O. (2004) Clozapine improves dyskinesias in Parkinson disease: a double-blind, placebo-controlled study. Neurology, 62(3): 381-388. 
Duvoisin, R.C. (1967) Cholinergic-anticholinergic antagonism in parkinsonism. Arch. Neurol., 17(2): 124-136.

Eberle-Wang, K., Lucki, I. and Chesselet, M.F. (1996) A role for the subthalamic nucleus in 5-HT2C-induced oral dyskinesia. Neuroscience, 72(1): 117-128.

Eberle-Wang, K., Mikeladze, Z., Uryu, K. and Chesselet, M.F. (1997) Pattern of expression of the serotonin2C receptor messenger RNA in the basal ganglia of adult rats. J. Comp. Neurol., 384(2): 233-247.

Eisensamer, B., Uhr, M., Meyr, S., Gimpl, G., Deiml, T., Rammes, G., Lambert, J.J., Zieglgansberger, W., Holsboer, F. and Rupprecht, R. (2005) Antidepressants and antipsychotic drugs colocalize with 5-HT3 receptors in raft-like domains. J. Neurosci., 25(44): 10198-10206.

Ellison, G. (1991) Spontaneous orofacial movements in rodents induced by long-term neuroleptic administration: a second opinion. Psychopharmacology (Berl.), 104(3): 404-408.

Ellison, G. and See, R.E. (1989) Rats administered chronic neuroleptics develop oral movements which are similar in form to those in humans with tardive dyskinesia. Psychopharmacology (Berl.), 98(4): 564-566.

el Mansari, M. and Blier, P. (1997) In vivo electrophysiological characterization of 5-HT receptors in the guinea pig head of caudate nucleus and orbitofrontal cortex. Neuropharmacology, 36(4-5): 577-588.

el Mansari, M., Radja, F., Ferron, A., Reader, T.A., MolinaHolgado, E. and Descarries, L. (1994) Hypersensitivity to serotonin and its agonists in serotonin-hyperinnervated neostriatum after neonatal dopamine denervation. Eur. J. Pharmacol., 261(1-2): 171-178.

Esposito, E., Di Matteo, V., Benigno, A., Pierucci, M., Crescimanno, G. and Di Giovanni, G. (2007a) Non-steroidal anti-inflammatory drugs in Parkinson's disease. Exp. Neurol., 205(2): 295-312.

Esposito, E., Di Matteo, V. and Di Giovanni, G. (2007b) Death in the substantia nigra: a motor tragedy. Expert Rev. Neurother., 7(6): 677-697.

Esposito, E., Di Matteo, V., Pierucci, M., Benigno, A. and Di Giovanni, G. (2007c) Role of central 5-ht2c receptor in the control of basal ganglia functions. In: Di Giovanni G. (Ed.), The basal ganglia pathophysiology: recent advances. Transworld Research Network, Trivandrum, pp. 97-127.

Fibiger, H.C. and Miller, J.J. (1977) An anatomical and electrophysiological investigation of the serotoninergic projection from the dorsal raphe nucleus to the substantia nigra in the rat. Neuroscience, 2: 975-987.

Filip, M., Bubar, M.J. and Cunningham, K.A. (2004) Contribution of serotonin (5-hydroxytryptamine; 5-HT) 5-HT2 receptor subtypes to the hyperlocomotor effects of cocaine: acute and chronic pharmacological analyses. J. Pharmacol. Exp. Ther., 310(3): 1246-1254.

Filip, M. and Cunningham, K.A. (2002) Serotonin 5-HT(2C) receptors in nucleus accumbens regulate expression of the hyperlocomotive and discriminative stimulus effects of cocaine. Pharmacol. Biochem. Behav., 71(4): 745-756.

Fletcher, P.J., Grottick, A.J. and Higgins, G.A. (2002) Differential effects of the $5-\mathrm{HT}(2 \mathrm{~A})$ receptor antagonist
M100907 and the 5-HT(2C) receptor antagonist SB242084 on cocaine-induced locomotor activity, cocaine self-administration and cocaine-induced reinstatement of responding. Neuropsychopharmacology, 27(4): 576-586.

Fletcher, S. and Barnes, N.M. (1999) Autoradiographic localization of the $[3 \mathrm{H}]-(\mathrm{S})$-zacopride labelled 5-HT3 receptor in porcine brain. Neurosci. Lett., 269(2): 91-94.

Flores, G., Rosales, M.G., Hernandez, S., Sierra, A. and Aceves, J. (1995) 5-Hydroxytryptamine increases spontaneous activity of subthalamic neurons in the rat. Neurosci. Lett., 192(1): 17-20.

Fox, S.H. and Brotchie, J.M. (2000a) 5-HT(2C) receptor antagonists enhance the behavioural response to dopamine $\mathrm{D}(1)$ receptor agonists in the 6-hydroxydopamine-lesioned rat. Eur. J. Pharmacol., 398(1): 59-64.

Fox, S.H. and Brotchie, J.M. (2000b) 5-HT2C receptor binding is increased in the substantia nigra pars reticulata in Parkinson's disease. Mov. Disord., 15(6): 1064-1069.

Fox, S.H., Moser, B. and Brotchie, J.M. (1998) Behavioral effects of 5-HT2C receptor antagonism in the substantia nigra zona reticulata of the 6-hydroxydopamine-lesioned rat model of Parkinson's disease. Exp. Neurol., 151(1): 35-49.

Frechilla, D., Cobreros, A., Saldise, L., Moratalla, R., Insausti, R., Luquin, M. and Del Río, J. (2001) Serotonin 5-HT $1 \mathrm{~A}$ receptor expression is selectively enhanced in the striosomal compartment of chronic parkinsonian monkeys. Synapse, 39(4): 288-296.

Garcia, L., D'Alessandro, G., Bioulac, B. and Hammond, C. (2005) High-frequency stimulation in Parkinson's disease: more or less? Trends Neurosci., 28(4): 209-216.

Gardell, L.R., Vanover, K.E., Pounds, L., Johnson, R.W., Barido, R., Anderson, G.T., Veinbergs, I., Dyssegaard, A., Brunmark, P., Tabatabaei, A., Davis, R.E., Brann, M.R., Hacksell, U. and Bonhaus, D.W. (2007) ACP-103, a 5-hydroxytryptamine $2 \mathrm{~A}$ receptor inverse agonist, improves the antipsychotic efficacy and side-effect profile of haloperidol and risperidone in experimental models. J. Pharmacol. Exp. Ther., 322(2): 862-870.

Gehlert, D.R., Gackenheimer, S.L., Wong, D.T. and Robertson, D.W. (1991) Localization of 5-HT3 receptors in the rat brain using [3H]LY278584. Brain Res., 553(1): 149-154.

Gehlert, D.R., Schober, D.A., Gackenheimer, S.L., Mais, D.E., Ladouceur, G. and Robertson, D.W. (1993) Synthesis and evaluation of [125I]-(S)-iodozacopride, a high affinity radioligand for 5HT3 receptors. Neurochem. Int., 23(4): 373-383.

Gerard, C., el Mestikawy, S., Lebrand, C., Adrien, J., Ruat, M., Traiffort, E., Hamon, M. and Martres, M.P. (1996) Quantitative RT-PCR distribution of serotonin $5-\mathrm{HT}_{6}$ receptor mRNA in the central nervous system of control or 5,7dihydroxytryptamine-treated rats. Synapse, 23(3): 164-173.

Gerard, C., Martres, M.P., Lefevre, K., Miquel, M.C., Verge, D., Lanfumey, L., Doucet, E., Hamon, M. and el Mestikawy, S. (1997) Immuno-localization of serotonin 5-HT 6 receptorlike material in the rat central nervous system. Brain Res., 746(1-2): 207-219.

Gerber, R., Altar, C.A. and Liebman, J.M. (1988) Rotational behavior induced by 8 -hydroxy-DPAT, a putative 5HT-1A 
agonist, in 6-hydroxydopamine-lesioned rats. Psychopharmacology (Berl.), 94(2): 178-182.

Gerfen, C.R. (1984) The neostriatal mosaic: compartmentalization of corticostriatal input and striatonigral output systems. Nature, 311(5985): 461-464.

Gerfen, C.R. (1985) The neostriatal mosaic. I. Compartmental organization of projections from the striatum to the substantia nigra in the rat. J. Comp. Neurol., 236(4): 454-476.

Goldstein, M., Anagnoste, B., Battista, A.F., Owen, W.S. and Nakatani, S. (1969) Studies of amines in the striatum in monkeys with nigral lesions. The disposition, biosynthesis and metabolites of $[3 \mathrm{H}]$ dopamine and $[14 \mathrm{C}]$ serotonin in the striatum. J. Neurochem., 16(4): 645-653.

Gong, L. and Kostrzewa, R.M. (1992) Supersensitized oral responses to a serotonin agonist in neonatal 6-OHDA-treated rats. Pharmacol. Biochem. Behav., 41(3): 621-623.

Gongora-Alfaro, J.L., Hernandez-Lopez, S., Flores-Hernandez, J. and Galarraga, E. (1997) Firing frequency modulation of substantia nigra reticulata neurons by 5-hydroxytryptamine. Neurosci. Res., 29(3): 225-231.

Granoff, M.I. and Ashby, C.R., Jr. (1998) The effect of the repeated administration of the compound 3,4-methylenedioxymethamphetamine on the response of rats to the 5-HT2A,C receptor agonist (+/-)-1-(2,5-dimethoxy-4-iodophenyl)-2aminopropane (DOI). Neuropsychobiology, 37(1): 36-40.

Grottick, A.J., Fletcher, P.J. and Higgins, G.A. (2000) Studies to investigate the role of $5-\mathrm{HT}_{(2 \mathrm{C})}$ receptors on cocaine- and food-maintained behavior. J. Pharmacol. Exp. Ther., 295(3): 1183-1191.

Guerra, M.J., Liste, I. and Labandeira-Garcia, J.L. (1997) Effects of lesions of the nigrostriatal pathway and of nigral grafts on striatal serotonergic innervation in adult rats. Neuroreport, 8(16): 3485-3488.

Guiard, B.P., el Mansari, M, Merali, Z. and Blier, P. (2008) Functional interactions between dopamine, serotonin and norepinephrine neurons: an in-vivo electrophysiological study in rats with monoaminergic lesions. Int. J. Neuropsychopharmacol., 21: 1-15.

Gunes, A., Dahl, M.-L., Spina, E. and Scordo, M. (2008) Further evidence for the association between 5-HT2C receptor gene polymorphisms and extrapyramidal side effects in male schizophrenic patients. Eur. J. Clin. Pharmacol., 64(5): 477-482.

Gunes, A., Scordo, M., Jaanson, P. and Dahl, M.-L. (2007) Serotonin and dopamine receptor gene polymorphisms and the risk of extrapyramidal side effects in perphenazine-treated schizophrenic patients. Psychopharmacology (Berl.), 190(4): 479-484.

Haapaniemi, T.H., Ahonen, A., Torniainen, P., Sotaniemi, K.A. and Myllyla, V.V. (2001) [123I]beta-CIT SPECT demonstrates decreased brain dopamine and serotonin transporter levels in untreated parkinsonian patients. Mov. Disord., 16(1): 124-130.

Haleem, D.J. and Khan, N.H. (2003) Enhancement of serotonin-1A receptor dependent responses following withdrawal of haloperidol in rats. Prog. Neuropsychopharmacol. Biol. Psychiatry, 27(4): 645-651.
Haleem, D.J., Samad, N. and Haleem, M.A. (2007a) Reversal of haloperidol-induced extrapyramidal symptoms by buspirone: a time-related study. Behav. Pharmacol., 18(2): 147-153.

Haleem, D.J., Samad, N. and Haleem, M.A. (2007b) Reversal of haloperidol-induced tardive vacuous chewing movements and supersensitive somatodendritic serotonergic response by buspirone in rats. Pharmacol. Biochem. Behav., 87(1): 115-121.

Haleem, D.J., Shireen, E. and Haleem, M.A. (2004) Somatodendritic and postsynaptic serotonin-1A receptors in the attenuation of haloperidol-induced catalepsy. Prog. Neuropsychopharmacol. Biol. Psychiatry, 28(8): 1323-1329.

Hall, H., Lundkvist, C., Halldin, C., Farde, L., Pike, V.W., McCarron, J.A., Fletcher, A., Cliffe, I.A., Barf, T., Wikstrom, H. and Sedvall, G. (1997) Autoradiographic localization of 5-HT1A receptors in the post-mortem human brain using [3H]WAY-100635 and [11C]WAY-100635. Brain Res., 745(1-2): 96-108.

Halliday, G.M., Blumbergs, P.C., Cotton, R.G.H., Blessing, W.W. and Geffen, L.B. (1990) Loss of brainstem serotoninand substance P-containing neurons in Parkinson's disease. Brain Res., 510(1): 104-107.

Hameleers, R., Blokland, A., Steinbusch, H.W.M., VisserVandewalle, V. and Temel, Y. (2007) Hypomobility after DOI administration can be reversed by subthalamic nucleus deep brain stimulation. Behav. Brain Res., 185(1): 65-67.

Hamon, M., Doucet, E., Lefevre, K., Miquel, M.C., Lanfumey, L., Insausti, R., Frechilla, D., Del Rio, J. and Verge, D. (1999) Antibodies and antisense oligonucleotide for probing the distribution and putative functions of central $5-\mathrm{HT}_{6}$ receptors. Neuropsychopharmacology, 21(2 Suppl): 68S-76S.

Hashimoto, K. and Kita, H. (2008) Serotonin activates presynaptic and postsynaptic receptors in rat globus pallidus. J. Neurophysiol., 99(4): 1723-1732.

Hawkins, M.F., Uzelac, S.M., Baumeister, A.A., Hearn, J.K., Broussard, J.I. and Guillot, T.S. (2002) Behavioral responses to stress following central and peripheral injection of the 5-HT2 agonist DOI. Pharmacol. Biochem. Behav., 73(3): 537-544.

Herrick-Davis, K., Grinde, E. and Teitler, M. (2000) Inverse agonist activity of atypical antipsychotic drugs at human 5-hydroxytryptamine 2 C receptors. J. Pharmacol. Exp. Ther., 295(1): 226-232.

Hervé, D., Pickel, V.M., Joh, T.H. and Beaudet, A. (1987) Serotonin axon terminals in the ventral tegmental area of the rat: fine structure and synaptic input to dopaminergic neurons. Brain Res., 435(1-2): 71-83.

Hicks, P.B. (1990) The effect of serotonergic agents on haloperidol-induced catalepsy. Life Sci., 47(18): 1609-1615.

Higgins, G.A., Jordan, C.C. and Skingle, M. (1991) Evidence that the unilateral activation of $5-\mathrm{HT}_{1 \mathrm{D}}$ receptors in the substantia nigra of the guinea-pig elicits contralateral rotation. Br. J. Pharmacol., 102(2): 305-310.

Hirst, W.D., Abrahamsen, B., Blaney, F.E., Calver, A.R., Aloj, L., Price, G.W. and Medhurst, A.D. (2003) Differences in the central nervous system distribution and pharmacology of the 
mouse 5-hydroxytryptamine-6 receptor compared with rat and human receptors investigated by radioligand binding, site-directed mutagenesis, and molecular modeling. Mol. Pharmacol., 64: 1295-1308.

Hirst, W.D., Minton, J.A., Bromidge, S.M., Moss, S.F., Latter, A.J., Riley, G., Routledge, C., Middlemiss, D.N. and Price, G.W. (2000) Characterization of [(125)I]-SB-258585 binding to human recombinant and native 5-HT(6) receptors in rat, pig and human brain tissue. Br. J. Pharmacol., 130(7): $1597-1605$.

Hoffman, B.J. and Mezey, E. (1989) Distribution of serotonin 5 -HT1C receptor mRNA in adult rat brain. FEBS Lett., 247(2): 453-462.

Horner, K.A., Adams, D.H., Hanson, G.R. and Keefe, K.A. (2005) Blockade of stimulant-induced preprodynorphin mRNA expression in the striatal matrix by serotonin depletion. Neuroscience, 131(1): 67-77.

Hornykiewicz, O. (1973) Dopamine in the basal ganglia: its role and therapeutic implications (including the clinical use of L-DOPA). Br. Med. Bull., 29(2): 172-178.

Hornykiewicz, O. (1998) Biochemical aspects of Parkinson's disease. Neurology, 51(2): S2-S9.

Hoyer, D., Hannon, J.P. and Martin, G.R. (2002) Molecular, pharmacological and functional diversity of 5-HT receptors. Pharmacol. Biochem. Behav., 71(4): 533-554.

Hoyer, D., Pazos, A., Probst, A. and Palacios, J.M. (1986) Serotonin receptors in the human brain. I. Characterization and autoradiographic localization of 5-HT1A recognition sites. Apparent absence of 5-HT1B recognition sites. Brain Res., 376(1): 85-96.

Ikeguchi, K. and Kuroda, A. (1995) Mianserin treatment of patients with psychosis induced by antiparkinsonian drugs. Eur. Arch. Psychiatry Clin. Neurosci., 244(6): $320-324$

Ikram, H., Samad, N. and Haleem, D.J. (2007) Neurochemical and behavioral effects of $\mathrm{m}-\mathrm{CPP}$ in a rat model of tardive dyskinesia. Pak. J. Pharm. Sci., 20(3): 188-195.

Invernizzi, R.W., Cervo, L. and Samanin, R. (1988) 8-Hydroxy2-(di-n-propylamino) tetralin, a selective serotonin1A receptor agonist, blocks haloperidol-induced catalepsy by an action on raphe nuclei medianus and dorsalis. Neuropharmacology, 27(5): 515-518.

Invernizzi, R.W., Pierucci, M., Calcagno, E., Di Giovanni, G., Di Matteo, V., Benigno, A. and Esposito, E. (2007) Selective activation of 5-HT2C receptors stimulates GABA-ergic function in the rat substantia nigra pars reticulata: a combined in vivo electrophysiological and neurochemical study. Neuroscience, 144(4): 1523-1535.

Ito, H., Halldin, C. and Farde, L. (1999) Localization of 5-HT1A receptors in the living human brain using [carbonyl11C]WAY-100635: PET with anatomic standardization technique. J. Nucl. Med., 40(1): 102-109.

Jackson, M.J., Al-Barghouthy, G., Pearce, R.K.B., Smith, L., Hagan, J.J. and Jenner, P. (2004) Effect of 5-HT1B/D receptor agonist and antagonist administration on motor function in haloperidol and MPTP-treated common marmosets. Pharmacol. Biochem. Behav., 79(3): 391-400.
Jacobs, B.L. and Azmitia, E.C. (1992) Structure and function of the brain serotonin system. Physiol. Rev., 72(1): 165-229.

James, T.A. and Starr, M.S. (1980) Rotational behaviour elicited by 5 -HT in the rat: evidence for an inhibitory role of 5-HT in the substantia nigra and corpus striatum. J. Pharm. Pharmacol., 32(3): 196-200.

Jellinger, K. (1987) Overview of morphological changes in Parkinson's disease. Adv. Neurol., 45: 1-18.

Johnson, S.W., Mercuri, N.B. and North, R.A. (1992) 5-hydroxytryptamine ${ }_{1 \mathrm{~B}}$ receptors block the $\mathrm{GABA}_{\mathrm{B}}$ synaptic potential in rat dopamine neurons. J. Neurosci., 12(5): 2000-2006.

Johnston, T.H. and Brotchie, J.M. (2006) Drugs in development for Parkinson's disease: an update. Curr. Opin. Investig. Drugs, 7(1): 25-32.

Kalkman, H.O., Neumann, V. and Tricklebank, M.D. (1997) Clozapine inhibits catalepsy induced by olanzapine and loxapine, but prolongs catalepsy induced by SCH 23390 in rats. Naunyn Schmiedebergs Arch. Pharmacol., 355(3): 361-364

Kehne, J.H., Ketteler, H.J., McCloskey, T.C., Sullivan, C.K., Dudley, M.W. and Schmidt, C.J. (1996) Effects of the selective 5-HT2A receptor antagonist MDL 100,907 on MDMA-induced locomotor stimulation in rats. Neuropsychopharmacology, 15(2): 116-124.

Kennett, G.A., Lightowler, S., de Biasi, V., Stevens, N.C., Wood, M.D., Tulloch, I.F. and Blackburn, T.P. (1994) Effect of chronic administration of selective 5-hydroxytryptamine and noradrenaline uptake inhibitors on a putative index of 5-HT2C/2B receptor function. Neuropharmacology, 33(12): $1581-1588$.

Kennett, G.A., Wood, M.D., Bright, F., Cilia, J., Piper, D.C., Gager, T., Thomas, D., Baxter, G.S., Forbes, I.T., Ham, P. and Blackburn, T.P. (1996) In vitro and in vivo profile of SB 206553, a potent 5-HT2C/5-HT2B receptor antagonist with anxiolytic-like properties. Br. J. Pharmacol., 117(3): 427-434

Kennett, G.A., Wood, M.D., Bright, F., Trail, B., Riley, G., Holland, V., Avenell, K.Y., Stean, T., Upton, N., Bromidge, S., Forbes, I.T., Brown, A.M., Middlemiss, D.N. and Blackburn, T.P. (1997) SB 242084, a selective and brain penetrant 5-HT2C receptor antagonist. Neuropharmacology, 36(4-5): 609-620.

Kerenyi, L., Ricaurte, G.A., Schretlen, D.J., McCann, U., Varga, J., Mathews, W.B., Ravert, H.T., Dannals, R.F., Hilton, J., Wong, D.F. and Szabo, Z. (2003) Positron emission tomography of striatal serotonin transporters in Parkinson disease. Arch. Neurol., 60(9): 1223-1229.

Khawaja, X. (1995) Quantitative autoradiographic characterisation of the binding of [3H]WAY-100635, a selective 5-HT1A receptor antagonist. Brain Res., 673(2): 217-225.

Kienzl, E., Riederer, P., Jellinger, K. and Wesemann, W. (1981) Transitional states of central serotonin receptors in Parkinson's disease. J. Neural. Transm., 51(1-2): 113-122.

Kim, S.E., Choi, J.Y., Choe, Y.S., Choi, Y. and Lee, W.Y. (2003) Serotonin transporters in the midbrain of Parkinson's 
disease patients: a study with 123I-\{beta\}-CIT SPECT. J. Nucl. Med., 44(6): 870-876.

Kish, S.J., Tong, J., Hornykiewicz, O., Rajput, A., Chang, L.J., Guttman, M. and Furukawa, Y. (2008) Preferential loss of serotonin markers in caudate versus putamen in Parkinson's disease. Brain, 131(1): 120-131.

Kita, H., Chiken, S., Tachibana, Y. and Nambu, A. (2007) Serotonin modulates pallidal neuronal activity in the awake monkey. J. Neurosci., 27(1): 75-83.

Kita, H. and Kitai, S.T. (1987) Efferent projections of the subthalamic nucleus in the rat: light and electron microscopic analysis with the PHA-L method. J. Comp. Neurol., 260(3): 435-452.

Kleven, M.S., Barret-Grevoz, C., Slot, L.B. and NewmanTancredi, A. (2005) Novel antipsychotic agents with 5-HT1A agonist properties: Role of 5-HT1A receptor activation in attenuation of catalepsy induction in rats. Neuropharmacology, 49(2): 135-143.

Knobelman, D.A., Kung, H.F. and Lucki, I. (2000) Regulation of extracellular concentrations of 5-hydroxytryptamine (5-HT) in mouse striatum by 5-HT1A and 5-HT1B receptors. J. Pharmacol. Exp. Ther., 292(3): 1111-1117.

Kohen, R., Metcalf, M.A., Khan, N., Druck, T., Huebner, K., Lachowicz, J.E., Meltzer, H.Y., Sibley, D.R., Roth, B.L. and Hamblin, M.W. (1996) Cloning, characterization, and chromosomal localization of a human 5-HT6 serotonin receptor. J. Neurochem., 66(1): 47-56.

Krack, P., Batir, A., Van Blercom, N., Chabardes, S., Fraix, V., Ardouin, C., Koudsie, A., Limousin, P.D., Benazzouz, A., LeBas, J.F., Benabid, A.-L. and Pollak, P. (2003) Five-year follow-up of bilateral stimulation of the subthalamic nucleus in advanced Parkinson's disease. N. Engl. J. Med., 349(20): 1925-1934.

Krack, P., Benazzouz, A., Pollak, P., Limousin, P., Piallat, B., Hoffmann, D., Xie, J. and Benabid, A.L. (1998) Treatment of tremor in Parkinson's disease by subthalamic nucleus stimulation. Mov. Disord., 13(6): 907-914.

Krebs-Thomson, K. and Geyer, M.A. (1996) The role of 5-HT(1A) receptors in the locomotor-suppressant effects of LSD: WAY-100635 studies of 8-OH-DPAT, DOI and LSD in rats. Behav. Pharmacol., 7(6): 551-559.

Kung, M.P., Frederick, D., Mu, M., Zhuang, Z.P. and Kung, H.F. (1995) 4-(2'-Methoxy-phenyl)-1-[2'-(n-2"'-pyridinyl)-piodobenzamido]-ethyl-piperazine ([125I]p-MPPI) as a new selective radioligand of serotonin-1A sites in rat brain: in vitro binding and autoradiographic studies. J. Pharmacol. Exp. Ther., 272(1): 429-437.

Kuoppamaki, M., Palvimaki, E.P., Hietala, J. and Syvalahti, E. (1995) Differential regulation of rat 5-HT2A and 5-HT2C receptors after chronic treatment with clozapine, chlorpromazine and three putative atypical antipsychotic drugs. Neuropsychopharmacology, 13(2): 139-150.

Kuoppamaki, M., Syvalahti, E. and Hietala, J. (1993) Clozapine and N-desmethylclozapine are potent 5-HT1C receptor antagonists. Eur. J. Pharmacol., 245(2): 179-182.

Laporte, A.M., Koscielniak, T.M., Ponchant, D., Vergé, M., Hamon, H. and Gozlan, H. (1992) Quantitative autoradiographic mapping of $5-\mathrm{HT}_{3}$ receptors in the rat CNS using $\left[{ }^{125} \mathrm{I}\right]$ iodo-zacopride and $\left[{ }^{1} \mathrm{H}\right]$ zacopride as radioligands. Synapse, 10(4): 271-281.

Laprade, N., Radja, F., Reader, T.A. and Soghomonian, J.-J. (1996) Dopamine receptor agonists regulate levels of the serotonin 5-HT2A receptor and its mRNA in a subpopulation of rat striatal neurons. J. Neurosci., 16(11): 3727-3736.

Lavoie, B. and Parent, A. (1990) Immunohistochemical study of the serotoninergic innervation of the basal ganglia in the squirrel monkey. J. Comp. Neurol., 299(1): 1-16.

Lee, M.S., Rinne, J.O. and Marsden, C.D. (2000) The pedunculopontine nucleus: its role in the genesis of movement disorders. Yonsei Med. J., 41(2): 167-184.

Leentjens, A.F.G. (2004) Depression in Parkinson's disease: conceptual issues and clinical challenges. J. Geriat. Psychiatr. Neurol., 17(3): 120-126.

Leentjens, A.F.G., Scholtissen, B., Vreeling, F.W. and Verhey, F.R.J. (2006) The serotonergic hypothesis for depression in Parkinson's disease: an experimental approach. Neuropsychopharmacology, 31(5): 1009-1015.

Leysen, J.E., Gommeren, W., Van Gompel, P., Wynants, J., Janssen, P.F. and Laduron, P.M. (1985) Receptor-binding properties in vitro and in vivo of ritanserin: a very potent and long acting serotonin-S2 antagonist. Mol. Pharmacol., 27(6): 600-611.

Limousin, P., Pollak, P., Benazzouz, A., Hoffmann, D., Le Bas, J.F., Broussolle, E., Perret, J.E. and Benabid, A.L. (1995) Effect of parkinsonian signs and symptoms of bilateral subthalamic nucleus stimulation. Lancet, 345(8942): 91-95.

Lopez-Gimenez, J.F., Mengod, G., Palacios, J.M. and Vilaro, M.T. (1997) Selective visualization of rat brain 5-HT2A receptors by autoradiography with [3H]MDL 100,907 . Naunyn Schmiedebergs Arch. Pharmacol., 356(4): 446-454.

Lopez-Gimenez, J.F., Mengod, G., Palacios, J.M. and Vilaro, M.T. (1999) Human striosomes are enriched in 5-HT2A receptors: autoradiographical visualization with [3H]MDL100,907, [125I] $( \pm)$ DOI and [3H]ketanserin. Eur. J. Neurosci., 11(10): 3761-3765.

Lucas, G., Bonhomme, N., Deurwaerdère, P.D., Moal, M.L. and Spampinato, U. (1997) 8-OH-DPAT, a 5-HT1A agonist and ritanserin, a 5-HT2A/C antagonist, reverse haloperidol-induced catalepsy in rats independently of striatal dopamine release. Psychopharmacology (Berl.), 131(1): 57-63

Lucas, G., De Deurwaerdère, P., Caccia, S. and Umberto, S. (2000) The effect of serotonergic agents on haloperidolinduced striatal dopamine release in vivo: opposite role of 5-HT2A and 5-HT2C receptor subtypes and significance of the haloperidol dose used. Neuropharmacology, 39(6): 1053-1063.

Maeda, T., Kannari, K., Shen, H., Arai, A., Tomiyama, M., Matsunaga, M. and Suda, T. (2003) Rapid induction of serotonergic hyperinnervation in the adult rat striatum with extensive dopaminergic denervation. Neurosci. Lett., 343(1): 17-20.

Mailly, P., Charpier, S., Menetrey, A. and Deniau, J.-M. (2003) Three-dimensional organization of the recurrent axon 
collateral network of the substantia nigra pars reticulata neurons in the rat. J. Neurosci., 23: 5247-5257.

Mander, A., McCausland, M., Workman, B., Flamer, H. and Christophidis, N. (1994) Fluoxetine induced dyskinesia. Aust. N. Z. J. Psychiatry, 28(2): 328-330.

Marazziti, D., Betti, L., Giannaccini, G., Rossi, A., Masala, I., Baroni, S., Cassano, G. and Lucacchini, A. (2001) Distribution of [3H]GR65630 binding in human brain postmortem. Neurochem. Res., 26(3): 187-190.

Martin-Cora, F.J. and Pazos, A. (2004) Autoradiographic distribution of 5-HT7 receptors in the human brain using $[3 \mathrm{H}]$ mesulergine: comparison to other mammalian species. Br. J. Pharmacol., 141(1): 92-104.

Martinez-Price, D.L. and Geyer, M.A. (2002) Subthalamic 5-HT1A and 5-HT1B receptor modulation of RU 24969induced behavioral profile in rats. Pharmacol. Biochem. Behav., 71(4): 569-580.

Matsubara, K., Shimizu, K., Suno, M., Ogawa, K., Awaya, T., Yamada, T., Noda, T., Satomi, M., Ohtaki, K.-I., Chiba, K., Tasaki, Y. and Shiono, H. (2006) Tandospirone, a 5-HT1A agonist, ameliorates movement disorder via non-dopaminergic systems in rats with unilateral 6-hydroxydopamine-generated lesions. Brain Res., 1112(1): 126-133.

Mayeux, R. (1990) The "serotonin hypothesis" for depression in Parkinson's disease. Adv. Neurol., 53: 163-166.

McQuade, R. and Sharp, T. (1995) Release of cerebral 5-hydroxytryptamine evoked by electrical stimulation of the dorsal and median raphe nuclei: effect of a neurotoxic amphetamine. Neuroscience, 68(4): 1079-1088.

Mehta, A., Eberle-Wang, K. and Chesselet, M.-F. (2001) Increased $\mathrm{m}$-CPP-induced oral dyskinesia after lesion of serotonergic neurons. Pharmacol. Biochem. Behav., 68(2): 347-353.

Mendlin, A., Martín, F.J. and Jacobs, B.L. (1999) Dopaminergic input is required for increases in serotonin output produced by behavioral activation: an in vivo microdialysis study in rat forebrain. Neuroscience, 93(3): 897-905.

Mengod, G., Pompeiano, M., Martinez-Mir, M.I. and Palacios, J.M. (1990) Localization of the mRNA for the 5-HT2 receptor by in situ hybridization histochemistry. Correlation with the distribution of receptor sites. Brain Res., 524(1): 139-143.

Mengod, G., Vilaro, M.T., Raurich, A., Lopez-Gimenez, J.F., Cortes, R. and Palacios, J.M. (1996) 5-HT receptors in mammalian brain: receptor autoradiography and in situ hybridization studies of new ligands and newly identified receptors. Histochem. J., 28(11): 747-758.

Middlemiss, D.N. and Hutson, P.H. (1990) The 5-HT1B receptorsAnn. N. Y. Acad. Sci., 600: 132-147. discussion 347-348

Mignon, L. and Wolf, W. (2002) Postsynaptic 5-HT1A receptors mediate an increase in locomotor activity in the monoamine-depleted rat. Psychopharmacology (Berl.), 163(1): 85-94.

Mignon, L. and Wolf, W. (2007) Postsynaptic 5-HT1A receptor stimulation increases motor activity in the 6-hydroxydopamine-lesioned rat: implications for treating
Parkinson's disease. Psychopharmacology (Berl.), 192(1): 49-59.

Mignon, L.J. and Wolf, W.A. (2005) 8-Hydroxy-2-(di-n-propylamino)tetralin reduces striatal glutamate in an animal model of Parkinson's disease. Neuroreport, 16(7): 699-703.

Miller, C.H., Fleischhacker, W.W., Ehrmann, H. and Kane, J.M. (1990) Treatment of neuroleptic induced akathisia with the 5-HT2 antagonist ritanserin. Psychopharmacol. Bull., 26(3): 373-376.

Miller, K.M., Okun, M.S., Fernandez, H.F., Jacobson, C.E., Rodriguez, R.L. and Bowers, D. (2007) Depression symptoms in movement disorders: comparing Parkinson's disease, dystonia, and essential tremor. Mov. Disord., 22(5): 666-672.

Miquel, M.C., Doucet, E., Boni, C., El Mestikawy, S., Matthiessen, L., Daval, G., Verge, D. and Hamon, M. (1991) Central serotonin1A receptors: respective distributions of encoding mRNA, receptor protein and binding sites by in situ hybridization histochemistry, radioimmunohistochemistry and autoradiographic mapping in the rat brain. Neurochem. Int., 19(4): 453-465.

Mitchell, I.J., Sambrook, M.A. and Crossman, A.R. (1985) Subcortical changes in the regional uptake of [3H]-2deoxyglucose in the brain of the monkey during experimental choreiform dyskinesia elicited by injection of a gammaaminobutyric acid antagonist into the subthalamic nucleus. Brain, 108(2): 405-422.

Miyawaki, E., Meah, Y. and Koller, W.C. (1997) Serotonin, dopamine, and motor effects in Parkinson's disease. Clin. Neuropharmacol., 20(4): 300-310.

Molina-Holgado, E., Dewar, K.M., Descarries, L. and Reader, T.A. (1994) Altered dopamine and serotonin metabolism in the dopamine-denervated and serotonin-hyperinnervated neostriatum of adult rat after neonatal 6- hydroxydopamine. J. Pharmacol. Exp. Ther., 270(2): 713-721.

Monsma, F.J., Jr., Shen, Y., Ward, R.P., Hamblin, M.W. and Sibley, D.R. (1993) Cloning and expression of a novel serotonin receptor with high affinity for tricyclic psychotropic drugs. Mol. Pharmacol., 43(3): 320-327.

Morales, M., Battenberg, E. and Bloom, F.E. (1998) Distribution of neurons expressing immunoreactivity for the $5 \mathrm{HT}_{3}$ receptor subtype in the rat brain and spinal cord. J. Comp. Neurol., 402(3): 385-401.

Moukhles, H., Bosler, O., Bolam, J.P., Vallée, A., Umbriaco, D., Geffard, M. and Doucet, G. (1997) Quantitative and morphometric data indicate precise cellular interactions between serotonin terminals and postsynaptic targets in rat substantia nigra. Neuroscience, 76(4): 1159-1171.

Mrini, A., Soucy, J.-P., Lafaille, F., Lemoine, P. and Descarries, L. (1995) Quantification of the serotonin hyperinnervation in adult rat neostriatum after neonatal 6-hydroxydopamine lesion of nigral dopamine neurons. Brain Res., 669(2): 303-308.

Naidu, P.S. and Kulkarni, S.K. (2001a) Effect of 5-HT1A and 5-HT2A/2C receptor modulation on neuroleptic-induced vacuous chewing movements. Eur. J. Pharmacol., 428(1): $81-86$. 
Naidu, P.S. and Kulkarni, S.K. (2001b) Reversal of neurolepticinduced orofacial dyskinesia by 5-HT3 receptor antagonists. Eur. J. Pharmacol., 420(2-3): 113-117.

Navailles, S., De Deurwaerdère, P. and Spampinato, U. (2006) Clozapine and haloperidol differentially alter the constitutive activity of central serotonin2C receptors in vivo. Biol. Psychiatry, 59(6): 568-575.

Nayak, S.V., Ronde, P., Spier, A.D., Lummis, S.C.R. and Nichols, R.A. (1999) Calcium changes induced by presynaptic 5-hydroxytryptamine-3 serotonin receptors on isolated terminals from various regions of the rat brain. Neuroscience, 91(1): 107-117.

Neal-Beliveau, B.S., Joyce, J.N. and Lucki, I. (1993) Serotonergic involvement in haloperidol-induced catalepsy. J. Pharmacol. Exp. Ther., 265(1): 207-217.

Nichols, R.A. and Mollard, P. (1996) Direct observation of serotonin 5-HT3 receptor-induced increases in calcium levels in individual brain nerve terminals. J. Neurochem., 67(2): 581-592.

Nicholson, S.L. and Brotchie, J.M. (2002) 5-Hydroxytryptamine (5-HT, serotonin) and Parkinson's disease-opportunities for novel therapeutics to reduce the problems of levodopa therapy. Eur. J. Neurol., 9(Suppl 3): 1-6.

Nishio, H., Kohno, Y., Fujii, A., Negishi, Y., Inoue, A. and Nakata, Y. (1996) 5-HT3 receptor blocking properties of the antiparkinsonian agent, talipexole. Gen. Pharmacol., 27(5): 779-785.

Numan, S., Lundgren, K.H., Wright, D.E., Herman, J.P. and Seroogy, K.B. (1995) Increased expression of 5HT2 receptor mRNA in rat striatum following 6-OHDA lesions of the adult nigrostriatal pathway. Brain Res. Mol. Brain Res., 29(2): 391-396.

O'Neill, M.F., Heron-Maxwell, C.L. and Shaw, G. (1999) 5-HT2 receptor antagonism reduces hyperactivity induced by amphetamine, cocaine, and MK- 801 but not D1 agonist C-APB. Pharmacol. Biochem. Behav., 63(2): 237-243.

Oberlander, C., Demassey, Y., Verdu, A., Van de Velde, D. and Bardelay, C. (1987) Tolerance to the serotonin 5-HT1 agonist RU 24969 and effects on dopaminergic behaviour. Eur. J. Pharmacol., 139(2): 205-214.

Oberlander, C., Hunt, P.F., Dumont, C. and Boissier, J.R. (1981) Dopamine independent rotational response to unilateral intranigral injection of serotonin. Life Sci., 28(23): 2595-2601.

Okazawa, H., Yamane, F., Blier, P. and Diksic, M. (1999) Effects of acute and chronic administration of the serotonin $1 \mathrm{~A}$ agonist buspirone on serotonin synthesis in the rat brain. J. Neurochem., 72(5): 2022-2031.

Oliver, K.R., Kinsey, A.M., Wainwright, A. and Sirinathsinghji, D.J. (2000) Localization of 5-ht(5A) receptor-like immunoreactivity in the rat brain. Brain Res., 867(1-2): $131-142$.

Olpe, H.R. and Koella, W.P. (1977) The response of striatal cells upon stimulation of the dorsal and median raphe nuclei. Brain Res., 122(2): 357-360.

Pakhotin, P. and Bracci, E. (2007) Cholinergic interneurons control the excitatory input to the striatum. J. Neurosci., 27(2): 391-400.
Park, M.R., Gonzales-Vegas, J.A. and Kitai, S.T. (1982) Serotonergic excitation from dorsal raphe stimulation recorded intracellularly from rat caudate-putamen. Brain Res., 243(1): 49-58.

Parker, R.M.C., Barnes, J.M., Ge, J., Barber, P.C. and Barnes, N.M. (1996) Autoradiographic distribution of [3H]-(S)-zacopride-labelled 5-HT3 receptors in human brain. J. Neurol. Sci., 144(1-2): 119-127.

Pasqualetti, M., Nardi, I., Ladinsky, H., Marazziti, D. and Cassano, G.B. (1996) Comparative anatomical distribution of serotonin $1 \mathrm{~A}, 1 \mathrm{D}$ [alpha] and $2 \mathrm{~A}$ receptor mRNAs in human brain postmorten. Brain Res. Mol. Brain Res., 39(12): 223-233.

Paulus, W. and Jellinger, K. (1991) The neuropathologic basis of different clinical subgroups of Parkinson's disease. J. Neuropathol. Exp. Neurol., 50(6): 743-755.

Pazos, A., Cortes, R. and Palacios, J.M. (1985) Quantitative autoradiographic mapping of serotonin receptors in the rat brain. II. Serotonin-2 receptors. Brain Res., 346(2): 231-249.

Pazos, A. and Palacios, J.M. (1985) Quantitative autoradiographic mapping of serotonin receptors in the rat brain. I. Serotonin-1 receptors. Brain Res., 346(2): 205-230.

Pazos, A., Probst, A. and Palacios, J.M. (1987a) Serotonin receptors in the human brain. III. Autoradiographic mapping of serotonin-1 receptors. Neuroscience, 21(1): 97-122.

Pazos, A., Probst, A. and Palacios, J.M. (1987b) Serotonin receptors in the human brain. IV. Autoradiographic mapping of serotonin-2 receptors. Neuroscience, 21(1): 123-139.

Perkins, M.N. and Stone, T.W. (1983) Neuronal responses to 5-hydroxytryptamine and dorsal raphe stimulation within the globus pallidus of the rat. Exp. Neurol., 79(1): 118-129.

Phelps, P.E., Houser, C.R. and Vaughn, J.E. (1985) Immunocytochemical localization of choline acetyltransferase within the rat neostriatum: a correlated light and electron microscopic study of cholinergic neurons and synapses. J. Comp. Neurol., 238(3): 286-307.

Pike, V.W., McCarron, J.A., Lammerstma, A.A., Hume, S.P., Poole, K., Grasby, P.M., Malizia, A., Cliffe, I.A., Fletcher, A. and Bench, C.J. (1995) First delineation of 5-HT1A receptors in human brain with PET and [11C]WAY-100635. Eur. J. Pharmacol., 283(1-3): R1-R3.

Pineyro, G. and Blier, P. (1999) Autoregulation of serotonin neurons: role in antidepressant drug action. Pharmacol. Rev., 51(3): 533-591.

Pires, J.G., Bonikovski, V. and Futuro-Neto, H.A. (2005) Acute effects of selective serotonin reuptake inhibitors on neuroleptic-induced catalepsy in mice. Braz. J. Med. Biol. Res., 38(12): 1867-1872.

Pompeiano, M., Palacios, J.M. and Mengod, G. (1992) Distribution and cellular localization of mRNA coding for 5-HT1A receptor in the rat brain: correlation with receptor binding. J. Neurosci., 12(2): 440-453.

Pompeiano, M., Palacios, J.M. and Mengod, G. (1994) Distribution of the serotonin 5-HT2 receptor family mRNAs: comparison between 5-HT2A and 5-HT2C receptors. Brain Res. Mol. Brain Res., 23(1-2): 163-178. 
Porras, G., Di Matteo, V., Fracasso, C., Lucas, G., De Deurwaerdere, P., Caccia, S., Esposito, E. and Spampinato, U. (2002) 5-HT2A and 5-HT2C/2B receptor subtypes modulate dopamine release induced in vivo by amphetamine and morphine in both the rat nucleus accumbens and striatum. Neuropsychopharmacology, 26(3): 311-324.

Prinssen, E.P., Koek, W. and Kleven, M.S. (2000) The effects of antipsychotics with $5-\mathrm{HT}(2 \mathrm{C})$ receptor affinity in behavioral assays selective for 5 -HT(2C) receptor antagonist properties of compounds. Eur. J. Pharmacol., 388(1): 57-67.

Queiroz, C.M. and Frussa-Filho, R. (1999) Effects of buspirone on an animal model of tardive dyskinesia. Prog. Neuropsychopharmacol. Biol. Psychiatry, 23(8): 1405-1418.

Querejeta, E., Oviedo-Chavez, A., Araujo-Alvarez, J.M., Quinones-Cardenas, A.R. and Delgado, A. (2005) In vivo effects of local activation and blockade of 5-HT1B receptors on globus pallidus neuronal spiking. Brain Res., 1043(1-2): 186-194.

Quirion, R. and Richard, J. (1987) Differential effects of selective lesions of cholinergic and dopaminergic neurons on serotonin-type 1 receptors in rat brain. Synapse, 1(1): 124-130.

Radja, F., Descarries, L., Dewar, K.M. and Reader, T.A. (1993) Serotonin 5-HT1 and 5-HT2 receptors in adult rat brain after neonatal destruction of nigrostriatal dopamine neurons: a quantitative autoradiographic study. Brain Res., 606(2): 273-285.

Rammes, G., Eisensamer, B., Ferrari, U., Shapa, M., Gimpl, G., Gilling, K., Parsons, C., Riering, K., Hapfelmeier, G., Bondy, B., Zieglgansberger, W., Holsboer, F. and Rupprecht, R. (2004) Antipsychotic drugs antagonize human serotonin type 3 receptor currents in a noncompetitive manner. Mol. Psychiatry, 9(9): 846-858.

Rauser, L., Savage, J.E., Meltzer, H.Y. and Roth, B.L. (2001) Inverse agonist actions of typical and atypical antipsychotic drugs at the human 5-hydroxytryptamine(2C) receptor. J. Pharmacol. Exp. Ther., 299(1): 83-89.

Reavill, C., Kettle, A., Holland, V., Riley, G. and Blackburn, T.P. (1999) Attenuation of haloperidol-induced catalepsy by a 5 -HT2C receptor antagonist. Br. J. Pharmacol., 126(3): $572-574$.

Rees, S., den Daas, I., Foord, S., Goodson, S., Bull, D., Kilpatrick, G. and Lee, M. (1994) Cloning and characterisation of the human 5-HT5A serotonin receptor. FEBS Lett., 355(3): 242-246.

Rempel, N.L., Callaway, C.W. and Geyer, M.A. (1993) Serotonin1B receptor activation mimics behavioral effects of presynaptic serotonin release. Neuropsychopharmacology, 8(3): 201-211.

Reynolds, G.P. (2004) Receptor mechanisms in the treatment of schizophrenia. J. Psychopharmacol. (Oxford), 18(3): 340-345.

Reynolds, G.P., Mason, S.L., Meldrum, A., De Keczer, S., Parnes, H., Eglen, R.M. and Wong, E.H. (1995) 5-Hydroxytryptamine (5-HT) 4 receptors in post mortem human brain tissue: distribution, pharmacology and effects of neurodegenerative diseases. Br. J. Pharmacol., 114(5): 993-998.
Riad, M., Mestikawy, S.E., Verge, D., Gozlan, H. and Hamon, M. (1991) Visualization and quantification of central 5-HT1A receptors with specific antibodies. Neurochem. Int., 19(4): 413-423.

Rick, C.E., Stanford, I.M. and Lacey, M.G. (1995) Excitation of rat substantia nigra pars reticulata neurons by 5-hydroxytryptamine in vitro: evidence for a direct action mediated by 5-hydroxytryptamine2C receptors. Neuroscience, 69(3): 903-913.

Ring, H.A. and Serra-Mestre, J. (2002) Neuropsychiatry of the basal ganglia. J. Neurol. Neurosurg. Psychiatry, 72: 12-21.

Roberts, J.C., Reavill, C., East, S.Z., Harrison, P.J., Patel, S., Routledge, C. and Leslie, R.A. (2002) The distribution of 5-HT(6) receptors in rat brain: an autoradiographic binding study using the radiolabelled 5-HT(6) receptor antagonist [(125)I]SB-258585. Brain Res., 934(1): 49-57.

Rodríguez, J.J., Garcia, D.R. and Pickel, V.M. (1999) Subcellular distribution of 5-hydroxytryptamine $2 \mathrm{~A}$ and $\mathrm{N}$-methylD-aspartate receptors within single neurons in rat motor and limbic striatum. J. Comp. Neurol., 413(2): 219-231.

Ronde, P. and Nichols, R.A. (1998) High calcium permeability of serotonin 5-HT3 receptors on presynaptic nerve terminals from rat striatum. J. Neurochem., 70(3): 1094-1103.

Rosengarten, H., Bartoszyk, G.D., Quartermain, D. and Lin, Y. (2006) The effect of chronic administration of sarizotan, 5-HT1A agonist/D3/D4 ligand, on haloperidol-induced repetitive jaw movements in rat model of tardive dyskinesia. Prog. Neuropsychopharmacol. Biol. Psychiatry, 30(2): 273-279.

Roth, B.L., Ciaranello, R.D. and Meltzer, H.Y. (1992) Binding of typical and atypical antipsychotic agents to transiently expressed 5-HT1C receptors. J. Pharmacol. Exp. Ther., 260(3): 1361-1365.

Roth, B.L., Meltzer, H.Y. and Khan, N. (1998) Binding of typical and atypical antipsychotic drugs to multiple neurotransmitter receptors. Adv. Pharmacol., 42: 482-485.

Ruat, M., Traiffort, E., Arrang, J.M., Tardivel-Lacombe, J., Diaz, J., Leurs, R. and Schwartz, J.C. (1993a) A novel rat serotonin (5-HT6) receptor: molecular cloning, localization and stimulation of cAMP accumulation. Biochem. Biophys. Res. Commun., 193(1): 268-276.

Ruat, M., Traiffort, E., Leurs, R., Tardivel-Lacombe, J., Diaz, J., Arrang, J.M. and Schwartz, J.C. (1993b) Molecular cloning, characterization, and localization of a high-affinity serotonin receptor (5-HT7) activating cAMP formation. Proc. Natl. Acad. Sci. U.S.A., 90(18): 8547-8551.

Rueter, L.E., Tecott, L.H. and Blier, P. (2000) In vivo electrophysiological examination of 5-HT2 responses in 5-HT2C receptor mutant mice. Naunyn Schmiedebergs Arch. Pharmacol., 361(5): 484-491.

Samad, N., Khan, A., Perveen, T., Haider, S., Abdul Haleem, M. and Haleem, D.J. (2007) Increase in the effectiveness of somatodendritic 5-HT-1A receptors in a rat model of tardive dyskinesia. Acta Neurobiol. Exp., 67(4): 389-397.

Sari, Y., Miquel, M.C., Brisorgueil, M.J., Ruiz, G., Doucet, E., Hamon, M. and Verge, D. (1999) Cellular and subcellular localization of 5-hydroxytryptamine1B receptors in the rat 
central nervous system: immunocytochemical, autoradiographic and lesion studies. Neuroscience, 88(3): 899-915.

Sawada, M., Nagatsu, T., Nagatsu, I., Ito, K., Iizuka, R., Kondo, T. and Narabayashi, H. (1985) Tryptophan hydroxylase activity in the brains of controls and parkinsonian patients. J. Neural Transm., 62(1-2): 107-115.

Scatton, B., Javoy-Agid, F., Rouquier, L., Dubois, B. and Agid, Y. (1983) Reduction of cortical dopamine, noradrenaline, serotonin and their metabolites in Parkinson's disease. Brain Res., 275(2): 321-328.

Schiller, L., Jahkel, M., Kretzschmar, M., Brust, P. and Oehler, J. (2003) Autoradiographic analyses of 5-HT1A and 5-HT2A receptors after social isolation in mice. Brain Res., 980(2): 169-178.

Scholtissen, B., Verhey, F.R., Steinbusch, H.W. and Leentjens, A.F. (2006) Serotonergic mechanisms in Parkinson's disease: opposing results from preclinical and clinical data. J. Neural Transm., 113(1): 59-73.

Schotte, A., Janssen, P.F., Megens, A.A. and Leysen, J.E. (1993) Occupancy of central neurotransmitter receptors by risperidone, clozapine and haloperidol, measured ex vivo by quantitative autoradiography. Brain Res., 631(2): 191-202.

Sethi, K.D. (2003) Tremor. Curr. Opin. Neurol., 16(4): 481-485.

Shen, K.Z. and Johnson, S.W. (2008) 5-HT inhibits synaptic transmission in rat subthalamic nucleus neurons in vitro. Neuroscience, 151(4): 1029-1033.

Shen, K.Z., Kozell, L.B. and Johnson, S.W. (2007) Multiple conductances are modulated by 5-HT receptor subtypes in rat subthalamic nucleus neurons. Neuroscience, 148(4): 996-1003.

Shilliam, C.S. and Dawson, L.A. (2005) The effect of clozapine on extracellular dopamine levels in the shell subregion of the rat nucleus accumbens is reversed following chronic administration: comparison with a selective 5-HT(2C) receptor antagonist. Neuropsychopharmacology, 30(2): 372-380.

Shink, E., Bevan, M.D., Bolam, J.P. and Smith, Y. (1996) The subthalamic nucleus and the external pallidum: two tightly interconnected structures that control the output of the basal ganglia in the monkey. Neuroscience, 73(2): 335-357.

Sian, J., Gerlach, M., Youdim, M.B. and Riederer, P. (1999) Parkinson's disease: a major hypokinetic basal ganglia disorder. J. Neural Transm., 106(5-6): 443-476.

Simola, N., Morelli, M. and Carta, A.R. (2007) The 6-hydroxydopamine model of Parkinson's disease. Neurotox. Res., 11(3-4): 151-167.

Sivam, S.P., Breese, G.R., Krause, J.E., Napier, T.C., Mueller, R.A. and Hong, J.S. (1987) Neonatal and adult 6-hydroxydopamine-induced lesions differentially alter tachykinin and enkephalin gene expression. J. Neurochem., 49(5): 1623-1633.

Smith, I.D. and Grace, A.A. (1992) Role of the subthalamic nucleus in the regulation of nigral dopamine neuron activity. Synapse, 12(4): 287-303.

Stachowiak, M.K., Bruno, J.P., Snyder, A.M., Stricker, E.M. and Zigmond, M.J. (1984) Apparent sprouting of striatal serotonergic terminals after dopamine-depleting brain lesions in neonatal rats. Brain Res., 291(1): 164-167.
Stanford, I.M., Kantaria, M.A., Chahal, H.S., Loucif, K.C. and Wilson, C.L. (2005) 5-Hydroxytryptamine induced excitation and inhibition in the subthalamic nucleus: action at 5-HT(2C), 5-HT(4) and 5-HT(1A) receptors. Neuropharmacology, 49(8): 1228-1234.

Stanford, I.M. and Lacey, M.G. (1996) Differential actions of serotonin, mediated by 5-HT1B and 5-HT2C receptors, on GABA-mediated synaptic input to rat substantia nigra pars reticulata neurons in vitro. J. Neurosci., 16(23): 7566-7573.

Stefani, A., Fedele, E., Mazzone, P., Galati, S., Tropepi, P. and Stanzione, P. (2006) In vivo microdialysis in parkinsonian patients undergoing stereotactic neurosurgery: key insights on DBS mechanisms of actions. In: Valentini, V., Di Chiara, G. (Eds.), Proceedings of the 11th International Conference of In Vivo Methods, University of Cagliari, Sardinia, Italy, pp. 74-76.

Stefani, A., Surmeier, D.J. and Kitai, S.T. (1990) Serotonin enhances excitability in neostriatal neurons by reducing voltage-dependent potassium currents. Brain Res., 529(1-2): 354-357.

Steffensen, S.C., Svingos, A.L., Pickel, V.M. and Henriksen, S.J. (1998) Electrophysiological characterization of GABAergic neurons in the ventral tegmental area. J. Neurosci., 18(19): 8003-8015.

Steinbusch, H.W. (1981) Distribution of serotonin-immunoreactivity in the central nervous system of the rat-cell bodies and terminals. Neuroscience, 6(4): 557-618.

Steward, L.J., Bufton, K.E., Hopkins, P.C., Davies, W.E. and Barnes, N.M. (1993) Reduced levels of 5-HT3 receptor recognition sites in the putamen of patients with Huntington's disease. Eur. J. Pharmacol., 242(2): 137-143.

Sturman, M.M., Vaillancourt, D.E., Metman, L.V., Bakay, R.A. and Corcos, D.M. (2004) Effects of subthalamic nucleus stimulation and medication on resting and postural tremor in Parkinson's disease. Brain, 127(Pt 9): 2131-2143.

Tarsy, D. and Baldessarini, R.J. (1984) Tardive dyskinesia. Annu. Rev. Med., 35: 605-623.

Tauscher, J., Kapur, S., Verhoeff, N.P., Hussey, D.F., Daskalakis, Z.J., Tauscher-Wisniewski, S., Wilson, A.A., Houle, S., Kasper, S. and Zipursky, R.B. (2002) Brain serotonin 5-HT(1A) receptor binding in schizophrenia measured by positron emission tomography and [11C]WAY-100635. Arch. Gen. Psychiatry, 59(6): 514-520.

Tepper, J.M. and Bolam, J.P. (2004) Functional diversity and specificity of neostriatal interneurons. Curr. Opin. Neurobiol., 14(6): 685-692.

Trevitt, J., Atherton, A., Aberman, J. and Salamone, J.D. (1998) Effects of subchronic administration of clozapine, thioridazine and haloperidol on tests related to extrapyramidal motor function in the rat. Psychopharmacology (Berl.), 137(1): 61-66.

Trevitt, J.T., Lyons, M., Aberman, J., Carriero, D., Finn, M. and Salamone, J.D. (1997) Effects of clozapine, thioridazine, risperidone and haloperidol on behavioral tests related to extrapyramidal motor function. Psychopharmacology (Berl.), 132(1): 74-81. 
Twarog, B.M. and Page, I.H. (1953) Serotonin content of some mammalian tissues and urine and a method for its determination. Am. J. Physiol., 175(1): 157-161.

Ullmer, C., Engels, P., Abdel'Al, S. and Lubbert, H. (1996) Distribution of 5-HT4 receptor mRNA in the rat brain. Naunyn Schmiedebergs Arch. Pharmacol., 354(2): 210-212.

Utter, A.A. and Basso, M.A. (2008) The basal ganglia: an overview of circuits and function. Neurosci. Biobehav. Rev., 32(3): 333-342.

Van Bockstaele, E.J., Biswas, A. and Pickel, V.M. (1993) Topography of serotonin neurons in the dorsal raphe nucleus that send axon collaterals to the rat prefrontal cortex and nucleus accumbens. Brain Res., 624(1-2): 188-198.

Van Bockstaele, E.J., Cestari, D.M. and Pickel, V.M. (1994) Synaptic structure and connectivity of serotonin terminals in the ventral tegmental area: potential sites for modulation of mesolimbic dopamine neurons. Brain Res., 647(2): 307-322.

Van Bockstaele, E.J. and Pickel, V.M. (1995) GABA-containing neurons in the ventral tegmental area project to the nucleus accumbens in rat brain. Brain Res., 682(1-2): 215-221.

Vandermaelen, C.P., Bonduki, A.C. and Kitai, S.T. (1979) Excitation of caudate-putamen neurons following stimulation of the dorsal raphe nucleus in the rat. Brain Res., 175(2): 356-361.

Varnas, K., Hall, H., Bonaventure, P. and Sedvall, G. (2001) Autoradiographic mapping of 5-HT(1B) and 5-HT(1D) receptors in the post mortem human brain using [(3)H]GR 125743. Brain Res., 915(1): 47-57.

Varnas, K., Hurd, Y.L. and Hall, H. (2005) Regional expression of 5-HT1B receptor mRNA in the human brain. Synapse, 56(1): 21-28.

Varnas, K., Thomas, D.R., Tupala, E., Tiihonen, J. and Hall, H. (2004) Distribution of 5-HT7 receptors in the human brain: a preliminary autoradiographic study using [3H]SB269970. Neurosci. Lett., 367(3): 313-316.

Veazey, C., Aki, S.O., Cook, K.F., Lai, E.C. and Kunik, M.E. (2005) Prevalence and treatment of depression in Parkinson's disease. J. Neuropsychiatry Clin. Neurosci., 17(3): 310-323.

Verge, D., Daval, G., Marcinkiewicz, M., Patey, A., el Mestikawy, S., Gozlan, H. and Hamon, M. (1986) Quantitative autoradiography of multiple 5-HT1 receptor subtypes in the brain of control or 5,7-dihydroxytryptaminetreated rats. J. Neurosci., 6(12): 3474-3482.

Vilaro, M.T., Cortes, R., Gerald, C., Branchek, T.A., Palacios, J.M. and Mengod, G. (1996) Localization of 5-HT4 receptor mRNA in rat brain by in situ hybridization histochemistry. Brain Res. Mol. Brain Res., 43(1-2): 356-360.

Vilaro, M.T., Cortes, R. and Mengod, G. (2005) Serotonin 5-HT4 receptors and their mRNAs in rat and guinea pig brain: distribution and effects of neurotoxic lesions. J. Comp. Neurol., 484(4): 418-439.

Waddington, J.L., Molloy, A.G., O'Boyle, K.M. and Mashurano, M. (1986) Motor consequences of D-1 dopamine receptor stimulation and blockade. Clin. Neuropharmacol., 9(4): $20-22$.
Wadenberg, M.L. (1996) Serotonergic mechanisms in neuroleptic-induced catalepsy in the rat. Neurosci. Biobehav. Rev., 20(2): 325-339.

Waeber, C., Dietl, M.M., Hoyer, D. and Palacios, J.M. (1989) 5.HT1 receptors in the vertebrate brain. Regional distribution examined by autoradiography. Naunyn Schmiedebergs Arch. Pharmacol., 340(5): 486-494.

Waeber, C., Schoeffter, P., Hoyer, D. and Palacios, J.M. (1990a) The serotonin 5-HT1D receptor: a progress review. Neurochem. Res., 15(6): 567-582.

Waeber, C., Sebben, M., Nieoullon, A., Bockaert, J. and Dumuis, A. (1994) Regional distribution and ontogeny of 5-HT4 binding sites in rodent brain. Neuropharmacology, 33(3-4): 527-541.

Waeber, C., Zhang, L.A. and Palacios, J.M. (1990b) 5-HT1D receptors in the guinea pig brain: pre- and postsynaptic localizations in the striatonigral pathway. Brain Res., 528(2): 197-206.

Ward, R.P. and Dorsa, D.M. (1996) Colocalization of serotonin receptor subtypes 5-HT2A, 5-HT2C, and 5-HT6 with neuropeptides in rat striatum. J. Comp. Neurol., 370(3): 405-414.

Ward, R.P., Hamblin, M.W., Lachowicz, J.E., Hoffman, B.J., Sibley, D.R. and Dorsa, D.M. (1995) Localization of serotonin subtype 6 receptor messenger RNA in the rat brain by in situ hybridization histochemistry. Neuroscience, 64(4): 1105-1111.

Weiner, D.M., Vanover, K.E., Brann, M.R., Meltzer, H.Y. and Davis, R.E. (2003) Psychosis of Parkinson's disease: serotonin 2A receptor inverse agonists as potential therapeutics. Curr. Opin. Investig. Drugs, 4(7): 815-819.

Wesolowska, A. (2002) In the search for selective ligands of 5-HT5, 5-HT6 and 5-HT7 serotonin receptors. Pol. J. Pharmacol., 54(4): 327-341.

Wilms, K., Vierig, G. and Davidowa, H. (2001) Interactive effects of cholecystokinin-8S and various serotonin receptor agonists on the firing activity of neostriatal neuronesin rats. Neuropeptides, 35(5-6): 257-270.

Wolf, W.A., Bieganski, G.J., Guillen, V. and Mignon, L. (2005) Enhanced 5-HT2C receptor signaling is associated with haloperidol-induced "early onset" vacuous chewing in rats: implications for antipsychotic drug therapy. Psychopharmacology (Berl.), 182(1): 84-94.

Wright, D.E., Seroogy, K.B., Lundgren, K.H., Davis, B.M. and Jennes, L. (1995) Comparative localization of serotonin1A, $1 \mathrm{C}$, and 2 receptor subtype mRNAs in rat brain. J. Comp. Neurol., 351(3): 357-373.

Xiang, Z., Wang, L. and Kitai, S.T. (2005) Modulation of spontaneous firing in rat subthalamic neurons by 5-HT receptor subtypes. J. Neurophysiol., 93(3): 1145-1157.

Yakel, J.L., Trussell, L.O. and Jackson, M.B. (1988) Three serotonin responses in cultured mouse hippocampal and striatal neurons. J. Neurosci., 8(4): 1273-1285.

Yoshioka, M., Matsumoto, M., Togashi, H. and Mori, K. (1998) Central distribution and function of 5-ht6 receptor subtype in the rat brain. Ann. N. Y. Acad. Sci., 861(1): p. 244. 
Zhang, Q.J., Gao, R., Liu, J., Liu, Y.P. and Wang, S. (2007) Changes in the firing activity of serotonergic neurons in the dorsal raphe nucleus in a rat model of Parkinsonos disease. Sheng Li Xue Bao, 59(2): 183-189.

Zhang, X., Andren, P.E., Greengard, P. and Svenningsson, P. (2008) Evidence for a role of the 5-HT1B receptor and its adaptor protein, p11, in L-DOPA treatment of an animal model of parkinsonism. Proc. Natl. Acad. Sci. U.S.A., 105(6): 2163-2168.
Zhang, X., Andren, P.E. and Svenningsson, P. (2007) Changes on 5-HT2 receptor mRNAs in striatum and subthalamic nucleus in Parkinson's disease model. Physiol. Behav., 92(1-2): 29-33. Zhou, F.C., Bledsoe, S. and Murphy, J. (1991) Serotonergic sprouting is induced by dopamine-lesion in substantia nigra of adult rat brain. Brain Res., 556(1): 108-116.

Zhou, F.M., Wilson, C.J. and Dani, J.A. (2002) Cholinergic interneuron characteristics and nicotinic properties in the striatum. J. Neurobiol., 53(4): 590-605. 